University of Louisville

ThinkIR: The University of Louisville's Institutional Repository

\title{
The problem of the twenty-first century in the Cherokee Nation is the problem of the color-line : how the Cherokee Freedmen have articulated a sense of cultural identity and citizenship claims over time.
}

Shannon Spears

University of Louisville

Follow this and additional works at: https://ir.library.louisville.edu/etd

Part of the Race, Ethnicity and Post-Colonial Studies Commons

\section{Recommended Citation}

Spears, Shannon, "The problem of the twenty-first century in the Cherokee Nation is the problem of the color-line : how the Cherokee Freedmen have articulated a sense of cultural identity and citizenship claims over time." (2014). Electronic Theses and Dissertations. Paper 1364.

https://doi.org/10.18297/etd/1364

This Master's Thesis is brought to you for free and open access by ThinkIR: The University of Louisville's Institutional Repository. It has been accepted for inclusion in Electronic Theses and Dissertations by an authorized administrator of ThinkIR: The University of Louisville's Institutional Repository. This title appears here courtesy of the author, who has retained all other copyrights. For more information, please contact thinkir@louisville.edu. 
THE PROBLEM OF THE TWENTY-FIRST CENTURY IN THE CHEROKEE NATION IS THE PROBLEM OF THE COLOR-LINE: HOW THE CHEROKEE FREEDMEN HAVE ARTICULATED A SENSE OF CULTURAL IDENTITY AND CITIZENSHIP CLAIMS OVER TIME

By

Shannon Spears

B.A. University of Louisville, 2011

\begin{abstract}
A Thesis
Submitted to the Faculty of the

College of Arts and Sciences of the University of Louisville

in Partial Fulfillment of the Requirements

For the Degree of
\end{abstract}

Master of Arts

Department of Pan-African Studies

University of Louisville

Louisville, KY

August 2014 
Copyright 2014 by Shannon M. Spears

All rights reserved 

THE PROBLEM OF THE TWENTY-FIRST CENTURY IN THE CHEROKEE NATION IS THE PROBLEM OF THE COLOR-LINE: HOW THE CHEROKEE FREEDMEN HAVE ARTICULATED A SENSE OF CULTURAL IDENTITY AND CITIZENSHIP CLAIMS OVER TIME

\section{By}

Shannon Spears

B.A. University of Louisville, 2011

A Thesis Approved on

July $11^{\text {th }}, 2014$

By the Following Thesis Committee:

Dr. Ricky Jones

Thesis Director

Dr. Latrica Best

Co-Chair

Dr. Selene Phillips 


\section{DEDICATION}

This thesis is dedicated to the PAS family from The Department of Pan-African Studies. Their encouragement and collaboration made all of this possible. 


\section{ACKNOWLEDGEMENTS}

I would like to thank Dr. Daniel Littlefield Jr. and the staff at the Sequoyah National Research Center. Their guidance and assistance through this research has been greatly treasured. I would like to thank John Chenault. You are a brilliant scholar, and I appreciate all of your wisdom and guidance with my research. I would especially like to thank Dr. Ricky Jones for chairing this thesis committee. Thank you to Dr. Latrica Best and Dr. Selene Phillips for sitting on my thesis committee. I know it has taken me longer than I thought to complete this thesis, and your patience, dedication, and time are greatly appreciated. I would like to give a special thanks to Dr. Carson Byrd. Your inspirational words always came at the right time and will be forever respected. Finally, I would like to thank my family and my graduate cohort for always listening to all of my thesis rants and for lifting my spirit. 


\begin{abstract}
THE PROBLEM OF THE TWENTY-FIRST CENTURY IN THE CHEROKEE NATION IS THE PROBLEM OF THE COLOR-LINE: HOW THE CHEROKEE FREEDMEN HAVE ARTICULATED A SENSE OF CULTURAL IDENTITY AND CITIZENSHIP CLAIMS OVER TIME
\end{abstract}

Shannon Spears

July 11 th, 2014

This research investigates the Cherokee Freedmen, who are people of AfricanAmerican descent and peoples of mixed African-American and Native American descent, who were once enslaved by Cherokees in the Cherokee Nation, and who have articulated their identity and tribal citizenship status as Cherokee Natives in the Cherokee Nation. Upon emancipation, the Cherokee Nation adopted the Cherokee Freedmen as equal citizens in the Cherokee Nation under article nine from the Treaty of 1866, but this changed after citizens were recorded on the Dawes Rolls based upon blood quantum. The theoretical framework of this research is Antonio Gramsci's theoretical perspective of cultural hegemony and core-periphery theory. Due to cultural hegemony, these citizenship rolls are still what articulate tribal citizenship status in the Cherokee Nation today. This research uses an Afro-Indigenous epistemological approach. Also, this Master's thesis addresses the identity politics behind citizenship status today for the descendants of Freedmen as well as legitimizes their authenticity as Cherokee Native citizens, for their citizenship status has been revoked from the Cherokee Nation, because they do not meet the required blood quantum. 
TABLE OF CONTENTS

PAGE

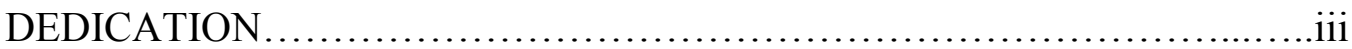

ACKNOWLEDGEMENTS .................................................

ABSTRACT ........................................................

TABLE OF CONTENTS ................................................. vi

LIST OF FIGURES.................................................. vii

CHAPTER I: INTRODUCTION.....................................

CHAPTER II: LITERATURE REVIEW ..............................8

CHAPTER III: THEORY AND METHODS ................................32

CHAPTER IV SOCIAL CHANNELS THAT HELPED IN THE CHEROKEE FREEDMEN IN THEIR ARTICULATION OF CULTURAL IDENTITY ......47

CHAPTER V: THE ORIGINAL RIGHTS OF CHEROKEE FREEDMEN AND HOW THEY HAVE CHANGED ......................................6 61

CHAPTER VI: FINDINGS ..........................................74

CHAPTER VII: DISCUSSION AND CONCLUSION ......................88

REFERENCES .................................................. 110

CURRICULUM VITAE.............................................. 123 


\section{LIST OF FIGURES}

FIGURE

PAGE

1. Illustration 4.1: Runaway Notice for Lucy from the Cherokee Phoenix.................101

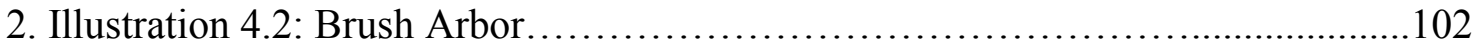

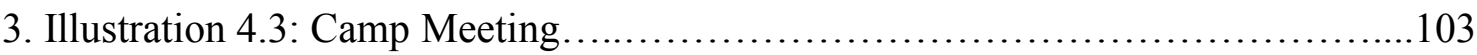

4. Illustration 5.1: Blue Card for tribal citizenship............................ 104

5. Illustration 5.2: CDIB for determining citizenship by blood....................105

6. Illustration 5.3: Cherokee citizenship "blue card" as a photo I.D................106

7. Illustration 5.4: Benefits of Employment in the Cherokee Nation ad.............. 107

8. Illustration 5.5: Dealership ad in the Cherokee Phoenix presenting a CDIB discount

of $\$ 500$ off on a new or used car................................................ 108

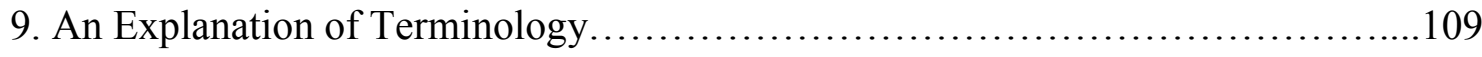




\section{CHAPTER I}

\section{INTRODUCTION}

\section{Background of Study}

Originally the idea of race did not exist among Cherokees. Cherokees would encounter Africans when in the company of Europeans, so Cherokees did not think that there was any form of racial hierarchy. Later, Cherokees figured out that Europeans saw Africans as inferior people. It could be argued that Cherokees started to figure out this hierarchy when Africans were escaping from the bondage of their white masters. There were Africans who sought and found refuge with Cherokees because they knew how to speak English. Cherokees developed a business type of partnership with Africans, for Africans could inform Cherokees on what white settlers were saying and doing.

Cherokees realized that they shared many similarities with Africans regarding their cultural traditions, but Cherokees worried that eventually they would be seen as inferior people too. ${ }^{1}$ Cherokees were enslaved alongside Africans, but Cherokees, however, had an advantage over enslaved Africans strictly because the Cherokees knew

\footnotetext{
${ }^{1}$ Perdue, T., Slavery and the Evolution of Cherokee Society, 1540-1866. (Knoxville, TN: The University of Tennessee Press), 1979, p.36.
} 
the land so well. ${ }^{2}$ White settlers realized that the enslavement of Africans was a better investment due to their displacement.

Cherokees avoided enslavement, losing their land, and their political rights by distancing themselves from Africans. ${ }^{3}$ Research explains how Cherokees enslaved African peoples and later "adopted" their Freedmen as "equal" citizens into their Nation upon emancipation. This adoption was through the implementation of the Treaty of 1866. Article nine of this treaty explains that the Freedmen were to be granted equal rights in the Cherokee Nation.

Unfortunately, because Cherokees misused the terms "adoption" and "equal" in the Treaty of 1866, it allowed Cherokees to limit Freedmen's citizenship status within the Cherokee Nation. Cherokees limited the Freedmen's citizenship status, by placing a deadline for Freedmen to return to the Cherokee Nation to obtain citizenship status. There were many Freedmen who did not meet the deadline and therefore were not granted citizenship status. Nevertheless, by putting these limitations on citizenship, does not make their citizenship status "equal" to those of Native Cherokees. ${ }^{4}$

However, the early contact and citizenship guidelines led to an eventual intermixing of both races and cultures. This intermixing led to double identity and "double consciousness" in that freed people in the Cherokee Nation became self-aware of

\footnotetext{
2 Ibid.

${ }^{3}$ Yarbrough, F., Race and the Cherokee Nation: Sovereignty in the Nineteenth Century. (Philadelphia, PA: University of Philadelphia Press), 2008, p.126.

${ }^{4}$ Saunt, C., "The Paradox of Freedom: Tribal Sovereignty and Emancipation of Indian Territory," The Journal of Southern History, 2004 1(70), p. 87.
} 
their "otherness." This awareness, has sparked controversy regarding their tribal identity and citizenship, for they are not seen as people having tribal identity and citizenship in regard to the current Cherokee Nation's citizenship policy. The dispute between the descendants of Freedmen and the Cherokee Nation is really an issue of identity politics.

In this Master's thesis, identity politics is defined as one identity group proving its legitimacy as members of another identity group. The recent controversy over citizenship status and voting rights regarding the descendants of Freedmen is an example of identity politics. The Freedmen descendants are having to prove their authenticity as Cherokee Natives to obtain equal citizenship status and voting rights. While there are some descendants of Freedmen who are able to prove their authenticity, there are many who are unable to prove their authenticity. Those who cannot are not considered Cherokee. The main purpose of this Master's thesis is to argue that although Freedmen descendants are people who make up a part of the African diaspora, their tribal identity and citizenship claims are as authentic as the tribal members of the Cherokee Nation.

\section{Research Questions and the Structure of this Thesis}

Who are the Cherokee Freedmen, and what defines their Cherokee citizenship?

Originally, the Cherokee Freedmen were people of African-American descent and people of both African-American and Native American descent, who were enslaved by Cherokees within the Cherokee Nation. The emancipation of the Freedmen in 1863 led to the development of the Treaty of 1866 . Article nine in the Treaty of 1866 stated that the

\footnotetext{
${ }^{5}$ Du Bois, W.E.B., The Souls of Black Folk, (New York, NY: Dover Publications, Inc.), 1994, pp. 2-3.
} 
Freedmen were to share the same rights as Cherokees. This meant that the Freedmen within the Cherokee Nation should have been granted equal citizenship rights, but many were not granted equal rights to citizenship in the Cherokee Nation. To obtain the rights as adopted citizens in the Cherokee Nation, certain requirements had to be met. This research will explain how the rights of Freedmen as citizens in the Cherokee Nation are not necessarily equal to those of Native Cherokees.

What is the Cherokee Nations' policy for obtaining tribal citizenship status?

Today, policy makers argue that Freedmen descendants do not meet the blood quantum requirement to be a Cherokee and thus are not considered citizens of the Cherokee Nation. The blood quantum requirement is based upon the Dawes Rolls recorded during the Dawes Age, which began in 1887. The literature review, which is found in chapter two, will provide background information regarding blood quantum policies and additional ways of obtaining Native citizenship.

What theories help shape Cherokee identity and African-American identity, and what historical theories change racial and cultural identity for both peoples?

The literature review will also discuss theories on both Cherokee identity and African-American identity. It is important to understand that Cherokees have always used blood to define Cherokee identity, but blood quantum was not a traditional method of defining Cherokee identity. It is also important during this discussion to explain how both Cherokee and African-American identities were classified by white settlers in early United States history. Antonio Gramsci's theories of cultural hegemony and core- 
periphery will be used to describe why Cherokees require blood quantum to prove Cherokee identity. These theories will be discussed in the third chapter on methodology with the discussion of Indigenous epistemology.

Chapter three will also discuss the literature that will be investigated for this study. This literature is valuable, for there is an absence of scholarly literature written on the current matters in regarding cultural identity and citizenship claims of the descendants of Freedmen.

What has been reported by Cherokees and Descendants of Freedmen?

In chapter six, this study will look at the Native newspaper reports from the Cherokee Phoenix. In the Cherokee Phoenix, citizens of the Cherokee Nation state their opinions on the current disputes on identity. The Cherokee Nation's opinions are important for this research, because these opinions are the foundation for the identity politics of the descendants of Freedmen. Legal documents from the descendants of Freedmen's court cases also will be examined in this study, for it is important to see the legal process backing the Freedmen descendants in their fight for Native citizenship. Lastly, the study will examine the Cherokee Nation Constitution, for the Constitution has been revised and edited throughout time. It is important to investigate the Constitution because there are revisions that could have a negative impact on Freedmen descendants' rights as citizens. Additionally, chapter six will provide information as to who the allies are in the Descendants of Freedmen's fight for tribal citizenship. Among these allies are David Cornsilk and Senator Diane Watson, who will be discussed in chapters six and seven. 
What factors help to shape the social construction of Cherokee identity for the Cherokee Freedmen and their descendants?

The identification of both cultural backgrounds is another form of double consciousness. How can the Freedmen descendants be told they are not Cherokee, when it is the only cultural lifestyle they have ever known? How can the Freedmen descendants be told to leave the Cherokee Nation and give up a major part of their cultural identity? Does this not in turn lead to an identity crisis? The Cherokee Freedmen and their descendants' self-identification as Cherokee Natives will be discussed in chapter four. Identity crisis will be discussed in chapters six and seven.

What are the current issues regarding citizenship for the Freedmen descendants in the Cherokee Nation?

The Cherokee Freedmen's fight for citizenship has been a long process. The reality is that the Freedmen and the descendants of the Freedmen, have always lived within, or close proximity to, the Cherokee Nation. Today the descendants of the Freedmen feel that they should be granted citizenship because of the Treaty of 1866 . In 2007 there was an election held where Cherokees voted on a new amendment for the Cherokee Nation Constitution. This amendment no longer allowed Freedmen descendants citizenship within the Cherokee Nation. What made this situation even worse is that the descendants of the Freedmen were not even allowed to vote in this election due to a ruling of the Cherokee Nation Supreme Court. This particular event and other events related to the current matters will be discussed in chapter five. 
Another problem the descendants of Freedmen encounter due to their disenfranchisement from the Cherokee Nation are losing tribal benefits. In addition to the status of citizenship there are other benefits to tribal citizenship, such as health and educational benefits. When many of the descendants were stripped of their citizenship status, these benefits were taken away as well. The loss of these benefits caused financial hardship for some of the descendants of Freedmen. This topic will also be covered in chapter five.

\section{Conclusion}

The purpose of this study is to see how the Cherokee Freedmen, who are people of mixed African and Native American ancestry, have articulated their sense of cultural identity. The citizenship status of Cherokee Freedmen has been granted and revoked over time. Additionally, this study focuses on the current situation of Freedmen descendants in regards to their authenticity as Cherokee Natives, for this is a situation that revolves around identity politics. This study aims to prove and explain their legitimacy as Cherokee people. 


\section{CHAPTER II}

\section{A REVIEW OF LITERATURE}

\section{Cherokee Identity}

"For thousands of years, the Cherokee people, or Ani-yunwi-ya, the Real People, defined themselves based on the Cherokee clan system, which delineates a relationship of consanguinity, specifically blood kinship of matrilineal descent."6 The seven clans of the Cherokee Nation are Deer, Wolf, Bird, Paint, Potato, Long Hair, and Blue. Clans are a part of the Cherokee life because it helps prevent incest and inbreeding. These clans are still a part of Cherokee life today.

Blood is a major part of Cherokee identity. It was believed that Cherokee identity was established through matrilineal descent because,

The Cherokee theory of procreation holds, in common with the beliefs of other Iroquoians, that the female contributes blood and flesh to the fetus, while the father provides the skeleton through agency of sperm, which can be considered a form of uncongealed bone. The blood tie of an Individual to a mother is thus regarded as a bond of living, procreative substance, not a metaphoric figure of speech. ${ }^{7}$

\footnotetext{
${ }^{6}$ Agent, D., "The Cherokee Nation Under Siege," Indivisible: African American Lives in the Americas, (Washington D.C., Washington: Smithsonian Books), 2009, p. 123.

${ }^{7}$ Fogelson, R., "On the 'Petticoat Government' of the Eighteenth-Century Cherokee" in Personality and the Cultural Construction of Society: Papers in Honor of Melford E. Spiro, (Tuscaloosa, AL: University of Alabama Press), 1990, pp.173-174.
} 
Members within Cherokee clans believed that they shared the same blood, which is also known as kinship in Cherokee culture. ${ }^{8}$ Because Cherokee clan members held the belief of sharing the same blood, members of clans were not allowed to marry within their mothers' or their fathers' clans. If members chose to do so, they would be punished by death. It was not until the $19^{\text {th }}$ century that the punishment of death was replaced with whipping. Members were encouraged to marry someone from their grandparents' clan. ${ }^{9}$ "Cherokees continued to define themselves in their own cultural terms as a people who were unified by kinship, language, and religious worldview and who differed according to their individual dialects, clans, roles, and town political agencies." ${ }^{10}$

\section{How Cherokee Identity was established under the Post-Colonial Scope}

It is important to note that before the contact between Cherokees and white settlers occurred, anyone could become a member of a Native nation. In fact there were even cases where,

Prisoners of war would often be taken into tribes and either kept as slaves or adopted as part of the clan, or family. The same held true when Native Americans began to capture white prisoners. Cherokee law allowed a person to claim whatever captive they might choose as either slave or family member. ${ }^{11}$

Sometimes people who were chosen as family members were adopted to replace a lost loved one. This adoption for tribal membership, under the view of the European postcolonial scope, was confusing. Europeans did not understand that,

\footnotetext{
${ }^{8}$ Sturm, C. Blood Politics: Race, Culture, and Identity in the Cherokee Nation of Oklahoma, (Berkeley and Los Angeles, CA: University of California Press), 2002, p.33.

${ }^{9}$ Ibid., p.31.

10 Ibid., p.43.

${ }^{11}$ Duvall, D., Tahlequah and the Cherokee Nation, (Chicago, IL: Arcadia Publishing), 2000, p.14.
} 
Both friends and former enemies (usually captives), but never a relative, could be adopted into a family and granted certain kinship rights in the clan. Along with these rights came obligations. Yet, the adoptee remain the person that he was, retaining his own family, clan identity, and kinship along with those he gained through adoption. ${ }^{12}$

As stated, friends and former enemies could be adopted into familial clans, which meant that African descent individuals could have been and were adopted into familial clans within the Cherokee Nation. There were also enslaved African descent people, who escaped from bondage, so that they could seek protection in Cherokee territory. It is important to note that Africans who sought refuge with the Cherokees had to be willing to fight in raids with them against European settlers. In addition, Africans knew how to speak English and were accustomed with the ways of the white settlers. ${ }^{13}$ Once Africans were adopted into Cherokee family clans, they were treated as if they were Cherokee themselves. ${ }^{14}$ There were also whites adopted in the Cherokee Nation, and once they were adopted, they were granted equal citizenship rights to those of Native Cherokees. ${ }^{15}$ This membership status meant that all of the people who inhabited the same Native nation had Cherokee tribal citizenship status regardless of their race. As more white settlers came into Cherokee territory, racial identity became more politicized.

\section{How Education from White Settlers Influenced Cherokee Identity}

White settlers influenced all Native Nations with their ideas of education.

However, the ideas of education through white settlers had a negative impact on the

\footnotetext{
12 Volo, D. and Volo, J., Family Life in Native America, (Westport, CT: Greenwood Press), 2007, p.51.

13 Michaels, S., "The Underground Railroad," The History Channel Recorded 1999, Triage Incorporated, 2002, VHS.

${ }^{14}$ Cumfer, C., Separate Peoples, One Land: The Minds of Cherokees, Blacks, and Whites on the Tennessee Frontier, (Chapel Hill, NC: The University of North Carolina Press), 2007, p.114.

${ }^{15}$ Duvall, D., Tahlequah and the Cherokee Nation, (Chicago, IL: Arcadia Publishing), 2000, p.14.
} 
Cherokee Nation. It could be argued that the early instruction began in 1803 during the Lewis and Clark Expedition. President Thomas Jefferson sent a letter with instructions to Captain Meriwether Lewis. In this letter, President Jefferson states that he wants Lewis to take notes on the Native American Nations that he comes in contact with along with notes on the population of those nations. Lewis was instructed to take particular notes on what possessions Natives had as well as what their tribal relations were toward other tribes from different nations. President Jefferson also wanted to know what languages were spoken, traditions that were practiced, the food that Natives ate, what clothing the Natives wore, their religious practices, and lastly what the Natives knew, for "as it may better enable those who may endeavor to civilize \& instruct them, to adapt their measures to the existing notions \& practices of those on whom they are to operate." ${ }^{16}$ In this letter, President Jefferson also tells Lewis that if any of the prominent chiefs would like to visit United States territory, then Lewis would need to make those arrangements. The observations were made by Lewis, but the ulterior motive for these observations was to civilize Natives. White settlers wanted land, so the idea was to civilize Native Americans in an attempt to obtain more land.

President Jefferson's instructions stated, "If any of them should wish to have some of their young people brought up with us, \& taught such arts as may be useful to them, we will receive, instruct, \& take care of them". ${ }^{17}$ It is important to note that Jefferson only makes an offer to instruct younger people from Native Nations, for it was believed that

\footnotetext{
${ }^{16}$ Jackson, D., Letters of Lewis and Clark Expedition With Related Documents: 1783-1854, (Urbana, IL: University of Illinois Press), 1962, pp. 62-63.

${ }^{17}$ Ibid.
} 
older generations could not assimilate to the ways of the white man due to tribal sovereignty. Elders wanted to protect and preserve their culture because they were proud of who they were as people. Thus, "the older generations were not capable of being civilized" in the eyes of the white man. ${ }^{18}$ However, the younger generations' minds were impressionable, and therefore they were capable of becoming civilized. This civilization was highly problematic regarding Native identity, for everything that was once known by children of Native Nations would be wiped out by boarding schools established both on and off reservations.

Many white settlers saw how spiritual Native Americans were, and realized that spirit played a major role in all aspects of life. In response, the earliest form of education for Native Americans was religious. Missionaries from several Christian denominations established boarding schools on reservations during the late $19^{\text {th }}$ and early $20^{\text {th }}$ centuries. These boarding schools were established on reservations in an effort to assimilate as many Native American children as possible. Each denominational school focused on the Christianization of Native students as well as reading, writing, and arithmetic. ${ }^{19}$ Religious institutions were primarily focused on stripping Native students of their own spirituality to immerse students to Eurocentric religiosity.

Non- reservation boarding schools were developed to fully assimilate the younger generations of Native Americans to the ways of the white man. For instance, in 1879, Carlisle Indian Industrial School became the first boarding school established for Native

\footnotetext{
${ }^{18}$ Adams, D., Education for Extinction: American Indians and the Boarding School Experience 1875-1928, (Lawrence, KS: University Press of Kansas), 1995, p. 18.

${ }^{19}$ Wickett, M., Contested Territory: Whites, Native Americans, and African Americans in Oklahoma 18651907, (Baton Rouge, LA: Louisiana State University Press), 2000, pp. 68-69.
} 
Americans located in Carlisle, Pennsylvania. The inspiration for this school came from Captain Richard Henry Pratt and his attempt at civilizing 72 Indian prisoners of war. ${ }^{20}$ Carlisle Indian Industrial School became the model for other non-reservation boarding schools. The main goal was to remove Native American children from their culture and place them in an institution where they would completely assimilate.

At boarding schools both on and off reservations, Native students' names, "which were often related to animals or events in the young child's life" were replaced with EuroAmerican names. ${ }^{21}$ Students were not allowed to speak their traditional languages, and were forced to speak English by their instructors. The idea of forced English speaking came from the Commissioner of Indian Affairs, who thought English should be the only language, and also believed if English was "good enough for a white man or a black man ought to be good enough for the red man. It is also believed that teaching an Indian youth his own barbarous dialect is a positive detriment to him."22 At boarding schools, Native students were stripped of their physical identity as well, and were not allowed to wear their traditional dress. Males had to cut their hair short and females were not allowed to wear braids.

Finally, young Natives were stripped of their cultural identity through the instruction of manual labor. Males were educated on the construction of wagons and houses, agriculture, and even blacksmithing. Females were instructed on how to do

\footnotetext{
${ }^{20}$ Pratt, R. and Utely R., Battlefield and Classroom: Four Decades with the American Indian, 1867-1904, (Norman, OK: University of Oklahoma Press), 2004, pp. xi-xv.

${ }^{21}$ Wickett, M., Contested Territory: Whites, Native Americans, and African Americans in Oklahoma 18651907, (Baton Rouge, LA: Louisiana State University Press), 2000, pp. 68-69.

${ }^{22}$ Strickland, R., The University of Kansas Law Review, Genocide- At-Law: An Historic and Contemporary View of the Native American Experience, 1986, Volume 34, p. 729.
} 
domestic duties such as cleaning, cooking, and sewing. ${ }^{23}$ It is important to understand that this not only happened in the Cherokee Nation, but in all Native Nations, and this education effected Cherokees cultural identity.

\section{Cherokee Language}

The Cherokees traditional language began as an oral tradition. Due to the influence of white settlers, the Cherokees traditional language additionally evolved into a written language. This written language has been practiced for over 100 years. Sequoyah, who was a Cherokee silversmith, was impressed by white settlers and their written communication. ${ }^{24}$ He developed the Cherokee syllabary, which consisted of 86 Characters. What is remarkable about this is Sequoyah "knew no English and did not know how to read or write in any language." However, "he did know that English speakers used 'talking leaves'; that is, they were able to represent their language with marks on paper." ${ }^{25}$ Even though it took Sequoyah twelve years to assemble the Cherokee syllabary, fellow members of the Cherokee Nation showed little to no interest in learning it until 1819 when,

A demonstration was arranged; a message was spoken to Sequoyah, who wrote it down in Cherokee. It was then sent to his daughter, who in turn read it back before a group of tribal leaders. According to all reports, the importance of this writing was recognized immediately." and "Within a year thousands of Cherokees had learned to read and write their native tongue. ${ }^{26}$

\footnotetext{
${ }^{23}$ Wickett, M., Contested Territory: Whites, Native Americans, and African Americans in Oklahoma 18651907, (Baton Rouge, LA: Louisiana State University Press), 2000, pp. 68-69.

${ }^{24}$ Davis, J. "The Life and Work of Sequoyah" Chronicles of Oklahoma 8(2), June 1930, viewed on May 19, 2014, http://digital.library.okstate.edu/chronicles/v008/v008p149.html

${ }^{25}$ Miller, W. and Sliver, S. American Indian Languages: Cultural and Social Contexts, (Tucson, AR: The University of Arizona Press) 1997, p. 195.

${ }^{26}$ Ibid. , pp. 197-198.
} 
Upon the establishment of their own written language, the Cherokees started to write their own newspaper.

In 1828 , the Cherokees were the first Native Americans to develop a newspaper the Cherokee Phoenix. Elias Boudinot, its' first editor, would go to philanthropy groups and religious groups to raise funds for the newspaper. Some parts of the Cherokee Phoenix were written in both Cherokee and English; however, writing in Cherokee did not take up as much space, "because the structure of the Sequoyah's written language devised single characters for whole syllables. ${ }^{27}$ As a result of how each language was written, not all of the newspapers had all of the articles in both Cherokee and English.

The Cherokees' intention behind the Cherokee Phoenix was to spread Christianity and to unite all Cherokees in the Nation as well as other peoples, so that they would have support in their fight to keep their homelands away from the federal government. Some of the other topics published in the newspaper were:

(1) Laws and documents of the nation; (2) accounts of manners and customs of Cherokees, and the progress in education, religion, and arts of civilized life, (3) principal interesting news of the day; and (4) miscellaneous articles, calculated to promote literature, civilization, art and religion. ${ }^{28}$

In 1829 , the Cherokees lengthened the name of the newspaper titled the Cherokee Phoenix and Indian Advocate. By changing the title, it allowed the Cherokees to talk about issues that other Native American nations faced. ${ }^{29}$ This newspaper paved the way

\footnotetext{
${ }^{27}$ Chao, Clint, \& Gutiérrez, Racism, Sexism, and the Media: The Rise of Class Communication in Multicultural America, (Thousand Oaks, CA: Sage Publications) 2003, p. 278.

${ }^{28}$ Martin, R., "The Cherokee Phoenix: Pioneer of Indian Journalism," Chronicles of Oklahoma 25, Summer 1947, pp. $102-118$

29 Ibid.
} 
for other Native American nations to write publications, which were written in a similar format.

\section{Changes in Racial Ideologies}

Cherokees used the term "red" to define themselves within the context of their cultural identity. Cherokees would use this term when referring to Cherokee mythology, for they believed that they were made of the earth. In this instance, earth means "red clay."30 "Red" as a racial label used to describe Cherokees, was imposed upon them by white settlers during the eighteenth century. White settlers wanted to differentiate their white racial identity from Cherokees and did so by labeling of skin tone. Cherokees were labeled as "red" or "redskins." These terms were used so often to label Cherokees that eventually Cherokees used them to define their own racial identity in opposition to white racial identity. ${ }^{31}$ This labeling of race made Cherokees view Africans differently, for Cherokees began to realize that there was a hierarchy between white settlers and Africans. This hierarchy consisted of white settlers being at the top and African peoples at the bottom.

While there were Cherokees who felt they had many similarities to Africans and wanted to befriend them, they knew that this friendship would place them at the bottom of the hierarchy. Nevertheless, Cherokees felt themselves to be above the white man, but because of white settlers and their need to "civilize" everyone else around them, this made Cherokees assimilate to white settlers' ways, so as to be seen as equals and also to be seen

\footnotetext{
${ }^{30}$ Shoemaker, N., "How Indians Got to be Red" in The American Historical Review. 1997, 102(3), p.641. ${ }^{31}$ Ibid. , p. 629.
} 
as "civilized" people. For Cherokees in particular, some of the "civilized" practices they adopted from white settlers included having a written language, adopting Eurocentric religion and education, capturing runaway slaves, and even owning slaves, which would put a large racial gap between the Cherokees and Africans. ${ }^{32}$

\section{Cherokee Freedmen and the Evolution of Citizenship Status}

There were Cherokees who owned slaves during enslavement. As a result, there were Cherokee slave owners who had relations with their slaves. Cherokees would also intermarry with people of African descent. These social interactions led to what started the group known as the Cherokee Freedmen, who are peoples of both African American ancestry and African-American and Native American mixed ancestry. ${ }^{33}$ The Cherokee Freedmen grew up in the Cherokee Nation and married other Freedmen or Natives within the nation. The Freedmen and their descendants have always had citizenship status within the Cherokee Nation beginning after emancipation in 1863. These rights of tribal citizenship were defined in Article 9 of the Treaty of 1866, which states,

The Cherokee Nation having, voluntarily, in February, eighteen hundred and sixtythree, by an act of the national council, forever abolished slavery, hereby covenant and agree that never hereafter shall either slavery or involuntary servitude exist in their nation otherwise than in the punishment of crime, whereof the party shall have been duly convicted, in accordance with laws applicable to all the members of the said tribe alike. They further agree that all freedmen who have been liberated by voluntary act of their former owners or by law, as well as all free colored persons who were in the country at the commencement of the rebellion, and are now residents therein or who may return within six months, and their descendants, shall have all the rights of native Cherokees: Provided, That owners

\footnotetext{
${ }^{32}$ Yarbrough, F., Race and the Cherokee Nation: Sovereignty in the Nineteenth Century, (Philadelphia, PA: University of Pennsylvania Press) 2008, p. 126.

${ }^{33}$ Holland, S., and Miles, T., Crossing waters crossing worlds: The African Diaspora in Indian Country, (Durham, NC: Duke University Press), 2006, p. 149.
} 
of slaves so emancipated in the Cherokee Nation shall never receive any compensation or pay for the slaves so emancipated. ${ }^{34}$

As stated earlier in Chapter one, the Freedmen were only granted "equal" rights to those of Native Cherokees if the Freedmen met the time requirement for returning to the Nation in six months. Those who did not meet this requirement and returned late were not considered citizens, but they were considered “intruders." However, Cherokees were granting citizenship and equal rights of citizenship to people of African descent, but due to imposed racism, this granting of citizenship ceased. White citizens were more desirable due to social order. However, white citizens were not granted equal rights of citizenship, but by granting more white settlers some form of citizenship in the Cherokee Nation, the Cherokees were able to establish their own hierarchy where,

It placed Cherokees on top, gave whites a not for their ability to uproot the Nation by allotting them intermediary status in the social order, and firmly consigned blacks to the bottom. By the end of the $\left[19^{\text {th }}\right]$ century, there was little space for individuals of African descent in the Cherokee Nation. ${ }^{35}$

As stated above, Cherokees wanted to be seen as equals to white settlers, so they "sought to redefine 'Indian' as more 'white' than 'black.", 36 At the start of the $20^{\text {th }}$ century in 1907, Indian Territory became known as the state of Oklahoma due to the push of the Dawes Act and the Curtis Act.

Today, the Cherokee Freedmen are grounding their argument for citizenship status on this particular article from the Treaty of 1866. However, the Cherokee Nation argues that the descendants of Freedmen do not meet the "blood quantum" requirement.

\footnotetext{
${ }^{34}$ Starr, E., History of the Cherokee Indians. (Cherokee, NC: Cherokee Publications), pp. 169-170.

${ }^{35}$ Yarbrough, F., Race and the Cherokee Nation: Sovereignty in the Nineteenth Century, (Philadelphia, PA: University of Pennsylvania Press) 2008, p. 125.

${ }^{36}$ Ibid.
} 
Originally, the Cherokee Nation did not have a blood quantum requirement, but when whites started mixing into the tribe it became a requirement. ${ }^{37}$

\section{The Origin of Blood Quantum}

Blood quantum was established by social scientists in the late $19^{\text {th }}$ century and the early $20^{\text {th }}$ century. Lewis Henry Morgan was the anthropologist and social theorist, who connected heritage through blood, which was both a false and racist conclusion. ${ }^{38}$. This led to cultural identity being constructed on a racial bias. ${ }^{39}$ Social scientists categorized people based upon comparative anatomy instead of looking at social characteristics because they believed that identity was biologically constructed. Many of these European scientists would measure and weigh skulls, document skin tones, as well as compare hair and facial features. For instance, "There are particular physical characteristics attributed to 'Indianness' — coarse straight black hair; ruddy complexion; high cheekbones; a pronounced nose."40 The Dawes Commission used blood quantum as well as physiology to distinguish those who were and were not of Cherokee descent.

\section{How Blood Quantum is Used Today}

Indian blood quantum is usually calculated through looking at the family tree. The parents' racial backgrounds are examined. Supposedly if the parents' Indian blood was pure, then their children would have the blood quantum of one hundred percent, but if the

\footnotetext{
${ }^{37}$ Brooks, J. Confounding the color line, (Lincoln and London, NE: University of Nebraska Press), 2002, pp. 12, 137-139.

38 Ibid.

${ }^{39}$ Berkhofer Jr., R., The White Man's Indian, (New York, NY: Random House Inc.) 1979, pp. 55-61.

${ }^{40}$ Merskin, D. What Does One Look Like?. Dressing in Feathers: The Construction of the Indian in American Popular Culture. Edited by S. Elizabeth Bird. (Boulder, CO: Westview Press), 1996. pp. 281-284.
} 
parents had racially mixed backgrounds, then their children would have fractional blood quanta. ${ }^{41}$ It might seem odd for a person to be classified as an "Indian" if their blood quantum is only $1 / 4$ or $1 / 8$, but their blood quantum is identified through the official classification. There are Certificates of Degree of Indian Blood cards, which serve as an identification card for proving ones' Native identity.

Some of these cards will actually show the person's blood quantum, however; there are many that do not. The main point of these identification cards is to represent tribal citizenship status and to show the individuals' connection to their nation. Robert Conley, a Cherokee author and scholar, explains that CDIBs are a way in which the federal government defines Cherokee Native identity, but he also explains that Cherokees have come to believe that CDIBs are what really defines someone's Cherokee identity. Conley also states that Cherokee citizens need to show their CDIBs when they vote in tribal elections and when students want to receive financial assistance to further their education. ${ }^{42}$ Legally a person may be "Indian" through the biological measure of blood quantum, but this is not something that is definitive.

The Bureau of Indian Affairs, BIA, "has been both a witness to and a principal player in the relationship between the Federal Government and Indian Tribes and Alaska Native villages." ${ }^{\text {"43 }}$ The BIA operates through four offices. These offices are: The Office of Indian Services, Justice Services, Trust Services, and Field Operations. In particular, the

\footnotetext{
${ }^{41}$ Wilkins, D., American Indian Politics and the American Political System. (Lanham, MD: Rowan and Littlefield Publishers Inc.) 2002, p. 24.

${ }^{42}$ Conley, R., Cherokee Thoughts: Honest and Uncensored. (Norman, OK: University of Oklahoma Press), 2008, pp. 151-153

${ }^{43}$ Bureau of Indian Affairs, "Who We Are" in U.S. Department of Indian Interior Indian Affairs, May $23^{\text {rd }}$ 2014, viewed on May 26 ${ }^{\text {th }}, 2014$, www.bia.gov .
} 
Division of Tribal Government in the Office of Indian Services is responsible for distributing CDIBs. "Tribal Government personnel, usually an Enrollment Clerk, located at a regional or agency office processes applications for Certificate Degree of Indian Blood (CDIB) ...to anyone who can provide documentation that he or she descends from an American Indian tribe." ${ }^{44}$ The Division of Tribal Government Services' mission is "To promote awareness of tribal governmental responsibilities and processes, and to provide tribes with the resources they need to foster strong and stable tribal governments in exercising their right as sovereign nations. ${ }^{{ }^{4} 5}$ It is important to understand what tribal sovereignty is, for this is one of the Cherokee Nations' arguments regarding the descendants of Freedmen's citizenship status.

\section{Tribal Sovereignty}

The reason why there are differing policies when it comes to tribal citizenship status is due to tribal sovereignty. "Nationalism or nationness ... "is a genre of claims, understandings, and grounds for recognizing, promoting, and legitimizing peoplehood, identity, and sovereignty." "46 Tribal sovereignty is about the supreme political power Native nations have over their own land, cultural identity, and citizenship status. This is why Native nations have strict policies when it comes to tribal citizenship. It could be argued that blood quantum policies negatively affect the longevity of tribal populations, as there are fewer people possessing these blood quanta over time. However, it is important

\footnotetext{
${ }^{44}$ Ibid.

${ }^{45}$ Ibid.

${ }^{46}$ Cornell, Stephen E., and Douglas H., "Mapping the Terrain," In Ethnicity and race: making identities in a changing world, 2nd ed. (Thousand Oaks, Calif.: Pine Forge Press, an Imprint of Sage Publication), 2007, pp. 15-40.
} 
to understand that these blood quantum policies are a way in which Native nations can protect themselves from outsiders trying to claim their connectedness to that particular nation without having any proof. ${ }^{47}$

\section{Grandfather Clauses and Marriage for Obtaining Tribal Citizenship Status into Native American Nations}

Today some nations are turning to familial lineage instead of blood quantum. This familial lineage is more like grandfathering people in to obtain more citizens. One example is White Earth Reservation, located in Minnesota, which is of Ojibwe lineage. The thought process is if there were people who had parents or grandparents who lived on the reservation, then they could register and obtain citizenship status. White Earth considered this because the residents at this particular reservation were concerned about the culture dying out. ${ }^{48}$ What is interesting to note is that the Cherokee Nation claims to have a blood quantum policy, but their policy basically states that if someone is able to trace their ancestry back to the Dawes Rolls, then they are considered Cherokee. How is this blood quantum when there is not an actual quantum or amount stated in their policy? What the Cherokee Nation policy is stating, is that if your ancestors and elders were citizens, then you can be a citizen too. Thus, Cherokee Nations' policy is essentially a grandfather clause.

\footnotetext{
${ }^{47}$ Kelly, R., Blood Speak: Ward Churchill and the Racialization of American Indian Identity, Communication and Critical/Cultural Studies, 2011, 8 (3), p. 242

${ }^{48}$ Robertson, T. "White Earth Nation Vote Could End 'Blood Quantum' Tribal Membership Requirement." (Ponsford, MN, MPRnews), 2013, http://www.mprnews.org/story/2013/11/20/politics/white-earth-bandvotes-to-end-blood-quantum-for-tribal-membership--. 
Marriage is another way in which someone may obtain citizenship status, but it is not necessarily tribal citizenship status. Depending on the regulations, non-Indians may and often do live on reservations. It is important to understand that Native American reservations serve as cultural spaces to preserve Native culture. In these spaces, Natives can speak their traditional languages, practice cultural traditions, foster a strong sense of family and community, and possess access to healthcare and social services. ${ }^{49}$ For many of the descendants of Freedmen, living and being a part of these spaces is an important part of their identity, for it is all they have ever known.

Historically, intermarriage would allow for tribal citizenship, for white women would intermarry into the Cherokee Nation. This was allowed because the white women were viewed as helping to civilize Cherokee men in the Nation. ${ }^{50}$ However, it was frowned upon for Cherokee women to intermarry with white men, although it still happened. ${ }^{51}$ Socrates, a Cherokee editorial writer for the Cherokee Phoenix, would often form opinions on intermarriages between Cherokee women and white men. His opinions made it seem that "white men easily and frequently took advantage of Cherokee women." 52 The downfall of Cherokee women marrying white men is that they would end up being in control of the land that was allotted to the Cherokee women. In many cases the men would turn around and sell the land.

\footnotetext{
${ }^{49}$ Sandefur, G., “American Indian reservations: The first underclass areas?” Focus, 1989, Summer (1), pp. 37-41.

50 Perdue, T., Mixed Blood Indians: Racial Construction in the Early South, (Athens, GA: University of Georgia Press) 2005, pp.70-103.

51 Socrates, Cherokee Phoenix March 27, 1828, (New Echota, GA).

52 Yarbrough, F., Race and the Cherokee Nation: Sovereignty in the Nineteenth Century. (Philadelphia, PA: University of Pennsylvania Press) 2008. p. 36.
} 
Before white settlers imposed racism into the minds of Cherokees, there were Cherokees who intermarried with Africans. "After one hundred and fifty years of interaction with British and Euro-American slaveholders, the Cherokee government delegitimized Cherokee families that included black members and outlawed marriage between Cherokees and black slaves, even as it legitimized Cherokee-white intermarriage. ${ }^{, 53}$ Because whites were allowed to intermarry with Cherokees, they could live in Cherokee territory. However, "free black men and women did not have these options. Cherokee law differentiated between blacks, and whites, but it did so in a way that elevated the position of whites in the nation over that of blacks." ${ }^{54}$ Today, people who are not of Native descent can intermarry and obtain citizenship status, which means that non-Natives can live on the reservation with their spouse, but they cannot be registered as tribal citizens.

As explained earlier, there were instances where both Africans and white settlers were adopted into Native Nations and obtained tribal citizenship status, but due to imposed racism, these adoptions became less legitimate. Therefore, people like the Cherokee Freedmen and their descendants, who once held equal citizenship status, no longer held this status. Today the descendants of Freedmen feel they should have rights to equal citizenship status and voting rights in the Cherokee Nation because of Article 9 in the Treaty of 1866. As stated earlier, the Treaty of 1866 still put limitations on citizenship, for it gives a six month return date. If Freedmen did not return to the

\footnotetext{
${ }^{53}$ Miles, T., Ties That Bind: The Story of an Afro-Cherokee Family in Slavery and Freedom, (Berkeley, CA: University of California Press) 2005, p.4.

${ }^{54}$ Ibid. , p.111.
} 
Cherokee Nation by the deadline stated, then they were excluded from citizenship.

Evelyn Nakano Glenn comments on the lack of citizenship in Constructing Citizenship:

Exclusion, Subordination, and Resistance. Glen stated,

Citizenship affects public life in such areas as political participation and development of state policy, it also affects private life, including family and interpersonal relationships. Lack of citizenship or legal status affects household formation and may indeed fracture families by separating members who have legal status from those who do not. ${ }^{55}$

In more modern times these adoptions are done as a way to honor someone. These adoptions do not grant tribal citizenship status or the rights of tribal citizens.

\section{The Early Construction of African-American Identity}

The first Africans to come to America "accompanied Columbus, Magellan, and other Europeans as explorers, servants, and slaves on their explorations of the world. The first Africans arrived in British North America, more specifically Jamestown, Virginia, in 1619." ${ }^{\circ 6}$ It is important to note that following settlement in Jamestown, Virginia, both Africans and Europeans became indentured servants to work off their debt that they accrued during their exploration. Another interesting point to note for this research is that not only were Africans sold and/or traded to Native Americans during this time, but white settlers were sold and/or traded as well. Colonist Henry Spelman was sold to Native Americans by Captain John Smith. ${ }^{57}$

\footnotetext{
${ }^{55}$ Glenn, E., "Constructing Citizenship: Exclusion, Subordination, and Resistance," American Sociological Review, 2011, 76(1), February $9^{\text {th }}$, p. 2 .

${ }^{56}$ Thyer, B., Cultural Diversity and Social Work Practice, (Springfield, IL: Charles Thomas Publisher, LTD), 2010, p.29.

${ }^{57}$ Giddings, P., When and Where I Enter: The Impact of Black Women on Race and Sex in America, (New York, NY: Bantam Books), 1985, p.29.
} 
Just like Native Americans, Europeans thought Africans were "heathens because they were not civilized and did not practice Christianity. Europeans believed slavery was a way to "save "or Christianize Africans. Europeans understood the color white represented things that were pure and noble because it was light, but thought that the color black represented things that were dirty and evil because it was dark. Additionally, "In most European languages, the word black was typically associated with aspects of death. The word death is derived from the Greek word necro, which means dead and is similar in sound and meaning to the word Negro." ${ }^{, 58}$ European settlers also believed in predestination, which depends on observation to separate who is going to heaven and who is not. People who were wealthy and independent were superior to people who were enslaved. ${ }^{59}$ Dr. Kwame Nantambu notes in his article Origins of terms 'Negro' and Afrika that,

In Euro-colonial countries, the word "Negro" had a specific meaning beyond the simple connotation of colour or skin. The expression, "He is a Negro," was equivalent to saying, "He is a slave". Since almost all the slaves in certain countries and epochs were "Negroes", "Negro" came to be synonymous with slave. ${ }^{60}$

For this research it is important to understand that Native Americans adopted the attitude of being superior to those who were enslaved from white settlers. Booker T. Washington noted this attitude in his autobiography Up From Slavery. He reflects on the time where he became a house father to Native American male students at Hampton Institute and

\footnotetext{
${ }^{58}$ Bowder, A., From the Browder File: 22 essays on the African American experience, (Washington, DC: Institute of Karmic Guidance), 1989, p.1.

${ }^{59}$ Chao, Clint, \& Gutiérrez. Racism, Sexism, and the Media: The Rise of Class Communication in Multicultural America, (Thousand Oaks, CA: Sage Publications), 2003, p.68.

${ }^{60}$ Nantambu, K., Origins of terms 'Negro' and Afrika, in Trinicenter.com. January $9^{\text {th }} 2007$, viewed on May 23, 2014, http://www.trinicenter.com/kwame/2007/0901.htm.
} 
wrote "I knew the average Indian felt himself above the white man, and of course, he felt himself above the Negro having submitting to slavery-a thing which the Indian would never do." $" 61$

\section{Displacement and Reclaiming of One's Self}

As a result of Africans being taken off the continent of Africa and forced into enslavement, African people became displaced physically and mentally. This displacement caused serious trauma. "They dismembered the colonized from memory, turning their heads upside down and burying all the memories they carried. Wherever they went, in their voyages of land, sea, and mind, Europeans planted their own memories on whatever they contacted." ${ }^{\prime 2}$ One major shift of Africans becoming African Americans was the shift in language. "Radically abstracted from their cultural communities, and broadly dispersed from plantation to plantation, state to state, and country to country, the African slaves in much of North America soon lost the capacity to speak their own African languages. ${ }^{963}$ In addition to losing their own traditional languages, Africans also lost their names. African names were replaced by their masters' names. This was a way for slave owners to show their dominance, for enslaved Africans were not seen as human beings. Instead they were viewed as property by their masters.

\footnotetext{
${ }^{61}$ Washington, B., Up From Slavery. (New York, NY: Doubleday and Company Inc.) 1963, pp. 68-69.

${ }^{62}$ Wa Thiongo, N., Something Torn and New: An African Renaissance. (New York, NY: Basic Civitas Books), 2009, p. 7.

${ }^{63}$ Gates Jr., H., Introduction: "Narration and Cultural Memory in the American Tradition": Talk That Talk: An Anthology of African-American Storytelling. Edited by Linda Goss and Marian E. Barnes. (New York, NY: Simon and Schuster), 1989, p. 15.
} 
While it was extremely risky, there were African Americans who escaped from the bondage of their masters in search of freedom. With this freedom came the reclaiming of one's self. Years after Frederick Douglass's escape for freedom, Douglass attended a meeting of the American Anti-Slavery Society in Nantucket Island, Massachusetts during the summer of 1841. William Lloyd Garrison, a determined American abolitionist, asked Frederick Douglass to speak at this meeting. In his speech about his experience during enslavement he stated "I stand before you this night as a thief and a robber, I stole this head, these limbs, this body from my master and ran off with them." ${ }^{\circ 4}$ Frederick Douglass is a prime example of how many African Americans reclaimed themselves as human beings.

\section{We the People}

It is important to understand that when the Constitution of the United States was written, "We the People" was exclusive of African Americans, Native Americans, and even white women. ${ }^{65}$ "We the People" really only referred to white men. It was not until 1865 that the $13^{\text {th }}$ amendment was not ratified to abolish slavery. The $14^{\text {th }}$ Amendment was ratified in 1868. In Section 1 of the $14^{\text {th }}$ Amendment it states,

All persons born or naturalized in the United States, and are subject to the jurisdiction thereof, are citizens of the United States and of the State wherein they reside. No State shall make or enforce any law which shall abridge the privileges or immunities of citizens of the United States; nor shall any State deprive any

\footnotetext{
${ }^{64}$ Haffner, Craig., "Frederick Douglass." A\&E Biography Recorded 1994, Greystone Communications Inc. 1994. VHS.

65 Gross, A., What Blood Won't Tell: A History of Race on Trial in America, (Cambridge, MA: Harvard University Press), 2008, p. 112.
} 
person of life, liberty, or property, without due process of law; nor deny to any person within its jurisdiction the equal protection of the laws. ${ }^{66}$

The $14^{\text {th }}$ Amendment is what granted United States citizenship to African Americans. Finally, the $15^{\text {th }}$ Amendment was ratified in 1870, which allowed African American males the right to vote.

\section{Racist Science used to Identify African Americans}

As stated earlier, social scientists from the $19^{\text {th }}$ and $20^{\text {th }}$ centuries based cultural identity on a racial bias of comparative anatomy and blood quantum. Like Native Americans, European scientists attributed physical characteristics of African people such as dark brown skin wooly hair, broad noses, and full lips. ${ }^{67}$ As far as blood quantum was concerned in regards to African Americans, there were differing labels for people who possessed any amount of African blood. These labels are "mulatto," "quadroon," "octoroon," and "Negro." "Mulatto" meant that a person was of mixed European and African ancestry. "Quadroon” meant that someone had 1/4 African ancestry. An "octoroon" was someone who had 1/8 African ancestry. The term "Negro" could be used to define whites as well as African Americans. The reason for this is because of the "onedrop rule," which was an unwritten law that was used to determine an individual's race. "Between Reconstruction and the turn of the century, the possibility of blacks passing as whites became an obsessive phobia on the part of the white southerners and a

\footnotetext{
${ }^{66}$ Constitution of the United States of America, Fourteenth Amendment, 1868, Library of Congress Virtual Programs and Services, "Primary Documents in American History." Fourteenth Amendment to the U.S. Constitution: Primary Documents of American History (Virtual Programs \& Services, Library of Congress). http://www.loc.gov/rr/program/bib/ourdocs/14thamendment.html (accessed February 19, 2014).

${ }^{67}$ Gates Jr. H., "Writing 'Race' and the Difference it Makes," Race, Writing, and Difference. (Chicago, IL: Chicago University Press) 1986. pp. 1-20.
} 
'temptation' to many whites with black ancestry." "68 Booker T. Washington supported social separation of the races and wrote "It is a fact that, if a person is known to have one percent of African blood in his veins, he ceases to be a white man. The ninety-nine percent of Caucasian blood does not weigh by the side of the one percent of African blood. The white blood counts for nothing. The person is a Negro every time." ${ }^{\prime \prime}$

\section{African American Identity as a Double Consciousness}

In 1903 William Edward Burghardt DuBois, an African-American sociologist and civil rights activist, wrote on the concept of "two-ness" and "double consciousness" in his book The Souls of Black Folk. The concept of "two-ness" and "double consciousness" are written in regards to African American identity and how it is a double identity. DuBois explains "The history of the American Negro is the history of strife, --- this longing to attain self-conscious manhood, to merge his double self into a better and truer self. In his merging, he wishes neither of the older selves to be lost. ... He simply wishes to make it possible for a man to be both a Negro and an American without being cursed and spit upon by his fellows" ${ }^{" 70}$ It is important to know and understand DuBois's concept for this area of research, for double consciousness is how the Cherokee Freedmen and their descendants identity is constructed. The Cherokee Freedmen want to not only be seen as African-Americans, but also as Native Cherokees as well. Another aspect of DuBois's concept of double consciousness that should be understood is both African-Americans and Cherokee Freedmen not only had to perceive and understand themselves identity

\footnotetext{
68 Zack, N., Race and Mixed Race. (Philadelphia, PA: Temple University Press) 1993. p. 83.

${ }^{69}$ Bramen, C., The Uses of Variety: Modern Americanism and the Quest for National Distinctiveness. (Cambridge, MA: Harvard University Press) 2000, p. 227.

${ }^{70}$ DuBois, W.E.B., The Souls of Black Folk, (New York, NY: Dover Publications, Inc.) 1994. pp. 2-3.
} 
wise, but also had to perceive and understand the ways in which others identify them as well. 


\section{CHAPTER III}

\section{THEORY \& METHODS}

\section{Theoretical Framework}

The theoretical framework of this study is based upon Antonio Gramsci's theory of cultural hegemony. ${ }^{71}$ Antonio Gramsci defined cultural hegemony as,

The 'spontaneous' consent given by the great masses of the population to the general direction imposed on by social life by the dominant fundamental group; this consent is 'historically' caused by the prestige (and consequent confidence) which the dominant group enjoys because of its position and function in the world of production. ${ }^{72}$

Gramsci also thought, "Hegemony must be based on a combination of coercion and consent." 73 Cultural hegemony is how a particular social and economic group of people maintain their authority over another group of people. This authority is about social and economic hold. Additionally, it is about the persuasiveness of the beliefs and thoughts that are forced upon those who are ruled to accept and follow. ${ }^{74}$

When white settlers came to North America, they wanted to establish their dominance over African slaves and Native populations. As a result, they developed the concept of the one drop rule, which assumed that if a person had one drop of any other

${ }^{71}$ Lears, Jackson, T.J., The Concept of Cultural Hegemony: Problems and Possibilities, 1985, 90 (3), pp. 567593.

${ }^{72}$ Gramsci, A., Selections from the Prison Notebooks, ed. and trans., Quentin Hoare and Geoffrey Nowell Smith (New York, NY: International Publishers) 1971, p. 12.

${ }^{73}$ McGhee, R., and Warms, R., Theory in Social and Cultural Anthropology: An Encyclopedia, (Thousand Oaks, CA: Sage Publications Inc.) 2013, p. 945.

${ }^{74}$ Joll, J., Antonio Gramsci (New York: NY, The Viking Press), 1977. p. 16. 
race in their blood, then that person was not of equal status. The concept of the one-drop rule was developed by white settlers and later adopted by Natives. For example, Natives originally thought peoples of mixed ancestry were superior to Africans when it came to racial hierarchy, but because of white settlers' firm belief in the one-drop rule, Natives would change their way of thinking. ${ }^{75}$ Unfortunately, the concept of the one-drop rule is still practiced today via the Cherokee Nations' Tribal Membership Card, which states each individual's blood quantum. This is just one of the ways that the Nation identifies members and non-members. Additionally, it is one of the ways that the Nation establishes its' dominance over the Cherokee Freedmen descendants, for the Tribal Membership Card is a status symbol of citizenship in the Cherokee Nation.

Core-periphery ties into this research because like Gramsci's theory of cultural hegemony, it involves the hierarchy of social and economic status. During his youth in Sardinia, Gramsci felt like an outcast for two reasons. First, Gramsci suffered from a hunchbacked condition. Gramsci, "Never grew to be more than four and three-quarters feet tall. He had two humps, one in the front and the other in the back, giving him a deformed appearance." ${ }^{76}$ His family lied about his condition and said it was caused by him falling down the stairs. During this time, it was believed that anyone who was a hunchback was considered to be evil or possessed by the devil. ${ }^{77}$ Secondly, Gramsci felt like an outcast because he was Sardinian. Even though Sardinia is an island and a region of Italy, Sardinia as a whole was treated as an outcast because it was, "Geographically

\footnotetext{
${ }^{75}$ Wickett, M., Contested territory: Whites, Native Americans, and African Americans in Oklahoma, 1865-1907 (Baton Rouge, LA: Louisiana State University Press), 2000, p. 70. ${ }^{76}$ Germaino, D., Antonio Gramsci: Architect of a New Politics, (Baton Rouge, LA: Louisiana State University Press), 1990, p. 1.

77 Ibid., pp. 1-2.
} 
isolated and poor in natural resources, Sardinia had been looked down upon by continental politicians even since Roman times." ${ }^{78}$ Thus, Sardinians were viewed as inferior by mainland Italians.

However, Sardinians were controlled by mainland Italians, "Who operated factories, held mining rights, and owned a significant portion of the agricultural land.",79 This was a result of hegemony, a combination of coercion and consent with mainland Italians. Mainland Italians had all the opportunities and advantages over Sardinians. Sardinians were the periphery society, while mainland Italians were the core society who maintained their dominance over peripheralists.

These peripheralists consisted of peasants, miners, and industrial workers who were treated poorly and were made to be dependent upon centralists. Essentially, the core society are takers, while the periphery society are makers. The core society benefits from the peripherals, but does not pay them fairly or include them in their social setting. This means that the peripherals are always outsiders looking into the core society.

In this research, white settlers represent the core society because of their established dominance over Cherokees. It could be argued that originally, Cherokees were represented as a peripheral society because they did not live the white man's way of life. Initially, Cherokees befriended and granted African descended individuals citizenship, but white settlers viewed people of African descent as inferior. When Cherokees realized this hierarchy, they believed that they too would be seen as inferior. As a way to improve their position in society, Cherokees not only adopted white settlers' ways of life, but also their

\footnotetext{
78 Ibid., p.8.

${ }^{79}$ Clayton, T., Rethinking Hegemony, (Melbourne, Australia: James Nicholas Publishers), 2006, p. 2.
} 
racial ideologies. While this act improved Cherokees position in society by not possessing the lowest rank on this hierarchal system in society, they still were not viewed as equals to white settlers thus only changing their social and economic status from peripheral to semiperipheral in core society. Even though the Cherokees position was improved in core society, Cherokee Freedmen were at the bottom of the hierarchy making them the periphery society.

Cherokees were not viewed as equals in the core society of white settlers. However, it could be argued that the Cherokees view themselves as the core society in the Cherokee Nation thus making the Cherokee Freedmen the periphery society. The Cherokee Nation is the core society in this case because they possess all of the opportunities and advantages over the Cherokee Freedmen and their descendants who were disenfranchised. Therefore, Freedmen descendants are now the outsiders looking into the core society.

Another way in which the Cherokee Nation has established its' dominance over the descendants of Freedmen is through the color-line. In addition to writing on his concept of African-American identity as a double-consciousness, DuBois also writes that the, "PROBLEM OF THE TWENTTIETH CENTURY is the problem of the color-line." 80 The issue of the color-line is in reference to racial segregation upon the abolishment of slavery. Currently, the descendants of Freedmen are facing the issue of the color-line, for they were recently disenfranchised from the Cherokee Nation. The descendants of Freedmen are no longer considered citizens in the Cherokee Nation due to the Dawes

${ }^{80}$ DuBois, W.E.B., The Souls of Black Folk. (New York, NY: Dover Publications, Inc.) 1994, p. 9. 
Commissions' forceful implementation of blood quantum and racial bias when determining tribal citizenship.

\section{Epistemological Approach}

DuBois's concept of the "problem of the color-line," lays the foundation for the epistemological approach for this area of research. The descendants of the Cherokee Freedmen are currently facing the problem of the color-line since they were expelled from the Cherokee Nation. Even though the descendants of Freedmen consider themselves to be Cherokee, the Cherokee Nation argues the Freedmen descendants are not Cherokee due to the blood quantum policy. In addition, "many Freedmen [who] identify as both African American and Indian, [is] causing some sort of resentment among Indians who do not believe that a person may be both." ${ }^{\prime 11}$ Considering many of the descendants of Freedmen identify as both African-American and Native American, this area of research has been conducted using an Afro-Indigenous epistemological approach.

An Afro-Indigenous epistemology is a merging of both Pan-African and Indigenous epistemology. An Afro-Indigenous epistemology is important for this study because of the double identity of the Cherokee Freedmen and their descendants. It would seem biased to only use an Indigenous epistemology or to only use a Pan-African epistemology. Indigenous research is ceremonial and communicating the findings of the research is ceremonial not only for the researcher but also for who or what is being

\footnotetext{
${ }^{81}$ Williamson, T., "The Plight of the "Nappy Headed" Indians: The Role of Tribal Sovereignty in the Systematic Discrimination Against Black Freedmen by the Federal Government and Native American Tribes," Michigan Journal of Race and Law, 2004, 10 (233), p. 262.
} 
researched as well. ${ }^{82}$ Importantly, it is the researchers' responsibility to make sure that this research is respectful and that the results of this study can be reciprocated to the community. ${ }^{83}$ The main aspects pulled here from Pan-African epistemology in relation to this study are healing and person. Healing involves, "Indigenous knowledge and its application is framed in the context of restoring or maintaining the physical, mental, and spiritual well-being of the person, family, community, as well as ensuring right relationships with the ancestral, spiritual, and natural worlds." ${ }^{84}$ Healing is a way for African-descended individuals to learn the truth about themselves. This aspect of PanAfrican epistemology will help African descended people within their family and community.

In addition to healing, "The Pan-African concept of person is in constant tension with the community: indigenous wisdom understands that individual activities impact the entire community, but also understands that each individual is unique." 85 This aspect is also important to understand because the descendants of Freedmen are at constant tension with the community, and they are also a unique part of the African diaspora.

\section{Methodology}

For this research, a qualitative discourse analysis of literature was conducted. This area of research uses a qualitative approach, because this study is more exploratory in that

\footnotetext{
82 Wilson, S., Research Is Ceremony: Indigenous Research Methods. (Nova Scotia, Canada Fernwood Publishing Company), 2008, pp. 74 and 77.

83 Ibid.

${ }^{84}$ Martin, D., "Pan African Metaphysical Epistemology: A Pentagonal Introduction" The Journal of Pan African Studies, 2008, 2(3): 219.

85 Ibid. , p. 213.
} 
it is an area that is not well researched. ${ }^{86}$ There have not been many scholarly texts written on the current issues the descendants of Freedmen are facing regarding their cultural identity and citizenship status as Native Cherokees. Not all Cherokees share the same opinion when it comes to the citizenship status and the Cherokee identity of the Freedmen descendants, so another reason why the qualitative approach is being used is because the approach focuses more on what Cherokees have said and their meaning behind what they have said ${ }^{87}$ This is a qualitative discourse analysis because it collectively looks through the literature and dialogue in relation to cultural identity and citizenship claims made by the Cherokee Freedmen and their descendants.

\section{What Has Been Reported About the Cherokees and Descendants of Freedmen?}

There are some key terms that were sought in the findings of the Cherokee Nations' newspaper and legal documents of the court cases involving the citizenship of the descendants of Freedmen. These key terms are: race, mixed race, identity, Cherokee identity, African American identity, citizenship, Treaty of 1866, voting rights, tribal sovereignty, blood quantum, blood policy, mixed blood, Freedmen, Freedman, African American, and Black. It is important to analyze this literature for these terms, for this analysis helps to answer the question of what has been reported from both the Cherokees and the descendants of Freedmen. The study looked at old public records regarding court cases to see what has been said and argued in the court cases, which were obtained from the Sequoyah National Research Center.

\footnotetext{
${ }^{86}$ Creswell, J., Research Design: Qualitative, Quantitative, and Mixed Method Approaches. 3rd. (Thousand Oaks, CA: Sage Publications), 2009, p. 98.

${ }^{87}$ Bryman, A., Social Research Methods, $4^{\text {th }}$, (Oxford, New York: Oxford University Press), 2012, pp. 402 and 714.
} 


\section{Where Was This Research Conducted and Why?}

A part of this research was conducted at the Sequoyah National Research Center in Little Rock, Arkansas. The Sequoyah National Research Center houses the largest archival collection of Native American periodicals in addition to a vast collection of Native American artwork by Native American artists. The collection of this research was supervised by Dr. Daniel Littlefield Jr., who is the Director of the Sequoyah National Research Center. Additionally he is a main scholar in this area of research and is the author of the text The Cherokee Freedmen From Emancipation to American Citizenship.

\section{Additional Resources Used for this Study}

This study is conducted through the analysis of both the primary sources and secondary sources. The primary sources provide dialogue from the Cherokee Nations' citizens as well as the descendants of Freedmen, who are individuals with a double consciousness. The Freedmen descendants' voices should be heard, for this further proves their connectedness to the Cherokee Nation. One of the key areas important to this study is Cherokee identity and how it has been constructed over time. This information is a significant part of this research, for it helps to answer the question on how the Cherokee Freedmen have articulated their cultural identity over time. It also proves that the descendants of Freedmen are people who make up another part of the African Diaspora. "Chapter IV on the Social Channels That Helped the Cherokee Freedmen in Their Articulation of Cultural Identity" and "Chapter V on the Original Rights of Cherokee Freedmen and How They Have Changed" will give support to what is found in these primary and secondary sources. 


\section{Primary Sources}

Legal documents from the court cases on the descendants of Freedmen: The descendants of Freedmen argue that they should be tribal citizens of the Cherokee Nation because of Article 9 from the Treaty of 1866. However, the Cherokee Nation argues that the Freedmen descendants should not be tribal citizens because they do not meet the blood quantum policy. The Cherokee Nations' argument against the Treaty of 1866 is also found in these documents. Cherokee Nation Constitution amendments are present. These legal documents aim to answer the question of how both Cherokees and descendants of Freedmen's argue tribal citizenship status. The legal documents provide dialogue for this argument. One court case that will be looked at in particular is descendant Lucy Allen's case.

Newspaper articles from the Cherokee Phoenix: The newspaper articles researched were written from 2006 to 2007 . This time frame represents the escalation of the debate over identity politics of the Freedmen descendants' tribal citizenship status escalates. These newspaper articles show all of the news that has been recorded throughout the descendants' fight for tribal citizenship and voting rights. There are also articles written on Cherokee identity as well.

\section{Opinions of Cherokee citizens written in Talking Circles section of the}

Cherokee Phoenix: Most of the opinions that will be analyzed are from the years 2006 to 2007. This is another source where dialogue is found not only from citizens of the Cherokee Nation but also from the descendants of Freedmen who are no longer granted citizenship status. Many of these opinions speak on the terms of tribal sovereignty. Some 
of the opinions speak on the terms of Cherokee identity and how Cherokee identity is defined. Included are opinions written by Marilynn Vann, who is the President of the Descendants of Freedmen Organization.

\section{Other Native American publications reporting on current issues regarding}

the Freedmen descendants: One article analyzed in this research comes from a 2008 issue of the publication Sho-Ban News, a newspaper covering Idahoan and Indian Country news. This article gives U.S. President Barack Obama's opinion on the identity politics of the descendants of Freedmen and tribal sovereignty. ${ }^{88}$ Two other articles were analyzed from the publication Indian Country Today Media Network, a weekly news magazine. One article written in January of 2012 provides a brief overview of the Freedmen descendants' fight for tribal citizenship status and information on the evolution of the blood quantum policy of the Cherokee Nation. This publication also gives important information on the Treaty of $1866 .{ }^{89}$ Another article written on November 2012 explains the current federal lawsuit filed against the Cherokee Nation. ${ }^{90}$ This article will be analyzed on the dialogue between the Cherokee Nation and the descendants of Freedmen.

\section{$\underline{\text { Secondary Sources }}$}

\section{Academic-Based Studies on the Current Problems of the Descendants of Freedmen}

\footnotetext{
88 “Obama: Let courts decide Freedmen issue," Sho-Ban News, May 14, 2008, p. 4.

89 Jennings, J. "Cherokee Freedmen: One Year Later" Indian Country Today Media Network, January 31,, 2012, pp. 1-2, viewed on July 13, 2013 http://www.indiancountrytodaymedianetwork.com/ict sbs/Cherokee-freedm.

${ }^{90}$ Monet, J., "Freedmen Present Case: D.C. Circuit hears oral arguments in Cherokee Freedmen treaty dispute; Cherokee Nation repeats call to dismiss the case" in Indian Country Today, 2012, 2(42) November 7, pp. 12-13.
} 
While several academic texts have been written regarding the historical construction of Cherokee identity and citizenship status, it is important for this research to examine what has already been studied regarding the current problems of the descendants of Freedmen. As stated earlier, not much has been written regarding the current issues of citizenship status and cultural identity. However, during this search, two academic-based studies were found. One study was found in a scholarly journal article from the Journal of Feminist Family Therapy titled, "Influences on Identity: A Grounded Theory Approach to Descendants of Freedmen." ${ }^{\text {91 }}$ This article compiled information on women, who are members of the Descendants of Freedmen Organization. These women gave reasons as to how they have established their Cherokee identity. This article is important to include in this research because it is another source that gives dialogue pertaining to the descendants of Freedmen's current problems of identity politics in the Cherokee Nation.

Another study was completed by Ronald D. Smith, a communication professor at Buffalo State University of New York and the Director of the American Indian Policy and Media Initiative. Smith's study on The Cherokee-Freedmen Story: What The Media Saw ${ }^{92}$ demonstrate why primary sources should be used in the findings of this study, for one of the main issues. These reports are often one-sided and only quote descendants of Freedmen and their allies or Principal Chief Chad Smith. This source is imperative for this area of research because it gives a different perspective on what has been recorded outside the Cherokee Nations' publication of The Cherokee Phoenix.

\footnotetext{
${ }^{91}$ Blakslee, S. \& Martin, M., "Influences on Identity: A Grounded Approach to Descendants of Freedmen" Journal of Feminist Family Therapy, 2009, 21(4) pp. 271-283.

${ }^{92}$ Smith, R., The Cherokee-Freedmen Story: What The Media Saw, Shoot The Indian: Media Misinterpretation and Native Truth, (Buffalo, NY: American Indian Policy and Media Initiative), 2007, viewed March 15, 2014, http://works.bepress.com/cgi/viewcontent.cgi?article=1001\&context=ronald_smith.
} 


\section{National Newspaper Articles}

Two news articles analyzed in this study were written by CNN News. One of the articles was analyzed for the terms of identity and citizenship. ${ }^{93}$ The second article was examined on voting rights. ${ }^{94}$ One article published in USA Today was analyzed on the self-identification of the descendants of Freedmen as well as how the Cherokee Freedmen's blood quantum was recorded by the Dawes Commission. ${ }^{95}$ An article published in The New York Times was examined for what it reports on identity and mixed race identities. ${ }^{96}$ Two articles published in the Arkansas Democrat-Gazette were analyzed on what has been reported on citizenship status ${ }^{97}$ and benefits of Cherokee citizenship..$^{98}$

\section{Magazine Articles}

An article published in Diverse magazine was analyzed for what was reported on the voting rights and benefits of Cherokee citizenship for the descendants of Freedmen. ${ }^{99}$ In an issue of Ebony magazine, an article was written on the Freedmen descendants fight for tribal citizenship status in the Cherokee Nation. In this article more dialogue is given

\footnotetext{
${ }^{93}$ CNN, "Pain of 'Trail of Tears' shared by Blacks as well as Native Americans", from CNN News Source, February 27, 2012, pp. 1-3 viewed June 28, 2013, www.Local10.com.

94 Stremlau, J., "Black Cherokees exercise hard-won right to vote," CNN News Source, Updated October 19, 2011, pp. 1-2, viewed June 11, 2013, www.cnn.com.

95 Hatton, L., "'Black' Cherokees fight for heritage,” USA Today, October 12, 2007.

${ }^{96}$ Staples, B., "When Racial Discrimination Is Not Just Black and White", The New York Times, September 12, 2003, pp. 2-3, viewed June 15, 2013, http://www.nytimes.com/2003/09/12/opinion/12FR13.html?ex=1064395438\&ei=1\&en=27e80bf3221f45 c7.

${ }^{97}$ Smith, R., "Cherokee Lawsuit's focus on Citizenship," Arkansas Democrat-Gazette, February 2009, pp. 14, viewed June 13, 2013 at http://www.nwnews.com/News/252575/.

98 Juozapavicius, J., "Cherokees revoke benefits for 2,008: Slaves' offspring cut from tribal rolls”, Arkansas Democrat-Gazette, September 10, 2011, p.5A.

${ }^{99}$ Cooper, K., "Citizenship Deferred: Descendants of Cherokee Slaves Known as Freedmen, Are Still Fighting for Rights and Basic Services," Diverse, 2011, pp. 12-13.
} 
to explain the descendants of Freedmen's self-identification as Cherokee Natives from Cherokee citizen David Cornslik. ${ }^{100}$

An article published in the magazine This Land was published to give an explanation of all of the court cases regarding the tribal citizenship status and voting rights of the Freedmen descendants. This article reports on Cornsilk, a Cherokee himself, who is an ally to the descendants of Freedmen in their fight for citizenship and voting rights. For this article, an analysis will be done on what was said about citizenship, tribal sovereignty, blood policy, identity, and voting rights. This article is important for this study, for it gives more dialogue on from an ally of the descendants of Freedmen who is also a Cherokee. ${ }^{101}$ Both of these articles are significant to investigate for this research because they answer the question, "Are there any Cherokees, who are allies to the Cherokee Freedmen and their descendants in their fight to be recognized as Cherokee citizens?"

\section{Importance of this Study}

This study is important, for it sheds light on both sides of the current problems of tribal citizenship status in the Cherokee Nation. At first glance, one might think that the expulsion of the descendants of Freedmen is an issue that is based upon racism and discrimination, but the Afro-Indigenous epistemology used in this research begs to look at the current issues regarding citizenship status from both sides. The current problems for Freedmen descendants should not only be viewed through a Pan-African lens but should also be viewed through an Indigenous lens as well. This research should not be one sided,

\footnotetext{
100 Samuels, A., “What Does Indian Blood Look Like?” Ebony, April 2008, pp. 94-104.

${ }^{101}$ Barbery, M., "From One Fire," This Land, 4(10), May 15, 2013, viewed July 15, 2013, http://thislandpress.com/05/16/2013/from-one-fire/?read=complete.
} 
for that would be disrespectful. It is imperative for these resources to be observed through both Pan-African and Indigenous lenses. There is no singular cultural experience regarding this topic of study. Through the investigation of the primary and secondary sources, interpretations of social constructs are taken from a comparison of how the Cherokee Freedmen articulate their cultural identity in various ways.

The study will also show how the Cherokee Nation views the Cherokee Freedmen and their descendants' cultural identity as well as how the Cherokee Nation grants the Freedmen descendants citizenship within the Cherokee Nation. The use of primary sources are important for the findings of this research because this study aims to acquire the opinions directly from the Cherokee Nation instead of just researching outside secondary sources. Yes, outside sources may be useful, but too often the journalists of these outside sources approach their reports without researching both sides of the story. Therefore, their reports come off as biased, as argued in Smith's study, The CherokeeFreedmen Story: What The Media Saw. ${ }^{102}$ By analyzing the Cherokee Nations' newspaper The Cherokee Phoenix and legal documents pertaining to citizenship, this will provide dialogue on the Cherokees opinions and views on these current issues.

It is imperative that tribal sovereignty is explained in this research because it helps everyone who is not a tribal citizen better understand why the Cherokee Nation is so adamant regarding their blood policy for obtaining tribal citizenship. People who are not tribal citizens need to understand that the Cherokee Nation has always determined for

\footnotetext{
102 Smith, R., The Cherokee-Freedmen Story: What The Media Saw, Shoot The Indian: Media Misinterpretation and Native Truth, (Buffalo, NY: American Indian Policy and Media Initiative), 2007, viewed on March 15, 2014, http://works.bepress.com/cgi/viewcontent.cgi?article=1001\&context=ronald_smith.
} 
themselves who they want as citizens. However, the Cherokee Nations' right of selfdetermination changed when the Dawes Commission, which acted as the original census bureau for the federal government, entered the Cherokee Nation and categorized its' citizens based upon a racial bias for their own benefit. Information on tribal sovereignty will be beneficial for people who are non-tribal citizens, for it will give them the much needed information they require before coming to the conclusion that the Cherokee Nation is racist.

This topic of study is distinctive in that it bridges the gap between Native American cultural studies and Pan-African cultural studies. It is also distinctive in that some of the court cases in regards to Cherokee citizenship are still pending, thus the arguments allotting the strengths and weaknesses for both the prosecution and defense have yet to be fully examined. 


\section{CHAPTER IV}

\section{SOCIAL CHANNELS THAT HELPED THE CHEROKEE FREEDMEN IN THEIR}

ARTICULATION OF CULTURAL IDENTITY

There are several ways in which the Cherokee Freedmen have articulated their cultural identity as Cherokee Natives. It is possible that this self-identification began when those who were enslaved by their Cherokee masters were given their masters surname. However, there are several other social factors that have contributed to the articulation of cultural identity. As previously explained, cultural identity is something that is socially constructed. This chapter explains the refuge that Africans sought from the Cherokee Nation was a social relationship that was and give information on the social struggle both enslaved Africans and Cherokees endured together. This study examines the traditions that were practiced both by Cherokee Freedmen and Cherokee Natives. This research will give insight on how the Cherokee Freedmen's Native identity is authentic to Native Cherokees. These examined traditions include oral tradition of Cherokee language and religion, music, and dance. Finally, this work will observe how the education of the Cherokee Freedmen was modeled after the industrialized education Native Cherokees received from the boarding schools they attended. Looking at the political rights and notable Cherokee Freedmen political leaders and the educational rights of Freedmen is necessary in that the research of these two channels show how the Freedmen were classified and identified by Native Cherokees within the Cherokee Nation. To conclude this chapter, the topics of owning land and citizenship status will be discussed. These are two other ways in which 
the Cherokee Freedmen self-identified as Cherokee, but these are also two ways in which Cherokee Natives would define Freedmen as “equal” Native Cherokees. However, this research will show that most of these "equal" rights were more "separate, but equal."

\section{The Struggle that both Enslaved Africans and Cherokees Endured}

Unfortunately, due to the greed of white settlers, the Indian Removal Act of 1830 was used to forcibly remove Cherokees out of their ancestral lands and into Indian Territory, which was land that was selected by the Federal Government for Cherokees and other Native Nations. This forced removal from ancestral lands was cultural genocide, for white settlers essentially wanted to wipe out Cherokees and other Nations' culture. This was essentially the white settlers' way of dealing with the "Indian Problem." This ethnic cleansing to Indian Territory is also known as the Trail of Tears. The Five Civilized Tribes, also known as the southeast Indians, were the ones who endured this forced relocation. The Five Civilized Tribes consists of the Creeks, Choctaws, Chickasaws, Seminoles, and Cherokees. Alongside these Natives were enslaved Africans. "Indeed, enslaved people represented a significant part of the inventory of property owned by these southeastern Indians." ${ }^{103}$ This is an important factor to mention, for the Cherokee Freedmen had ancestors who walked the Trail of Tears. This was a tragedy and a struggle the Five Civilized Tribes and enslaved Africans experienced together. It has been estimated that "one-third $(4,000)$ of the 12,000 Cherokees who participated died."104 However, estimates of how many enslaved Africans who died during this forced removal remain unknown. Nevertheless, the social construction of Cherokee identity for Cherokee

\footnotetext{
${ }^{103}$ Naylor, C., African Cherokees in Indian Territory From Chattel to Citizens, (Chapel Hill, NC: The University of North Carolina Press), 2008 p. 1.

104 Ibid.
} 
Freedmen and their descendants is not only structured on historical events like the Trail of Tears, but it is also socially constructed on the traditions that have been practiced by the Cherokee Freedmen and their descendants.

\section{The Beginnings: Ancestral Background for Cherokee Freedmen and Their Descendants}

Enslaved Africans were separated from their customs due to displacement. Africans traditional languages were replaced with European languages. When Cherokees first came into contact with Africans, they realized that Africans could speak English. Cherokee Natives had Africans act as liaisons to bridge the language gap between themselves and white settlers. For Africans to communicate effectively with Cherokees, Africans had to be somewhat familiar with the Cherokee language. It is important to note that Africans, who acted as liaisons essentially worked for Cherokees. Not only were they responsible for finding out what white settlers were up to and relaying that information to Cherokees, but Africans were also responsible for fighting alongside Cherokees in whatever battles they fought. The Cherokees acceptance of the refuge of Africans, who escaped from bondage of their white masters, was strictly business. ${ }^{105}$ Due to the fact that Cherokees eventually wanted to be seen as equal to white settlers, they adopted the concept of enslaving Africans.

\section{Cherokee Language as an Oral Tradition}

Tradition is a constant process across time and in time, linking past with present, thus ensuring continuity. It is also dynamic and ever-changing as culture and societal needs alter. One of the elusive but preserving cultural bases which bind

\footnotetext{
105 Michaels, S., "The Underground Railroad," The History Channel, Recorded 1999, Triage Incorporated, 2002, VHS.
} 
people to one another, it unites individuals and refutes the isolation and insularity man as a social being fears. ${ }^{106}$

One tradition that has changed over time due to needs of the cultural milieu, is language. Even the Cherokee language changed to meet with needs of the cultural milieu. Originally the Cherokee language was only a spoken language, which would make it an oral tradition within Cherokee culture. Oral tradition is important to discuss for this tradition leads to the practice of spoken traditional Cherokee language between Cherokee Natives and Cherokee Freedmen. Thus, traditional Cherokee language was spoken during religious practices and musical traditions shared between Cherokee Freedmen and Cherokee Natives.

During enslavement, there were individuals of both African American and mixed African and Native descent, who were born in the Cherokee Nation. As a result, Cherokee was their first language. There were also individuals of mixed African and Native descent who were bilingual. "Bilingualism expressed a degree of acculturation and belonging for some enslaved African Indians. Thus, there were enslaved African Indians, whose primary language was not English, but Cherokee."107 Those who were bilingual were trusted by their Cherokee masters' as translators when communicating with white settlers. ${ }^{108}$

It is also important to note that just like white masters, Cherokee masters were not allowed by law to educate enslaved individuals on how to read and write. This is another example that proves that the Cherokee language is an oral tradition, for this was the

\footnotetext{
106 Brown, M., Burns and Tradition (Champaign, IL: University of Illinois Press), 1984, p. xii.

107 Naylor, C., African Cherokees in Indian Territory: From Chattel to Citizens (Chapel Hill, NC: The University of North Carolina Press), 2008, pp.98-99.

108 Miles, T. Ties That Bind: The Story of an Afro-American Cherokee Family in Slavery and Freedom, (Berkeley, CA: University of California Press), 2005, p.96.
} 
language that was learned by being a member of this cultural environment. There is also evidence of Cherokee Freedmen's understanding of the Cherokee language shown in the Cherokee Nations' newspaper Cherokee Phoenix and Indians Advocate. This evidence can be seen in Illustration 4.1 found on page 113. This illustration shows a runaway notice for Lucy, who was enslaved by a Cherokee master. In this notice, physical descriptions of Lucy's appearance are given. Another important descriptive detail given about Lucy is that she, "speaks very broken English, having been raised in the Cherokee Nation speaks Cherokee Language." 109

\section{Cherokee Freedmen, Oral Tradition, and Religion in the Cherokee Nation}

It could be argued that enslaved individuals helped missionaries spread Christianity throughout the Cherokee Nation upon their forced removal and settling into Indian Territory. The reason for this is because these enslaved individuals were able to communicate with Cherokee people. ${ }^{110}$ As previously stated, the Cherokee language was learned by enslaved individuals through oral tradition because by law Cherokee masters were not allowed to educate those who were enslaved. However, the practice of speaking the Cherokee language as an oral tradition carried over into the religious practices of individuals who were enslaved by Cherokees. Oral tradition of the Cherokee language was practiced in songs and bible verses.

A Cherokee Freedwoman, Mrs. Chaney Richardson, recalls her attendance at church during her enslavement. She wrote that the church was, "a church made out of

\footnotetext{
${ }^{109}$ Hollingsworth, T., \$20 Reward in Cherokee Phoenix \& Indians Advocate, 1832, 4(27). 110 Ibid.
} 
brush arbor and would sing good songs in Cherokee sometimes." 111 She also wrote, "I've been a good church goer all my life until I git too feeble, and I still understand and talk Cherokee language and I love to hear songs and parts of the Bible in it because it makes me think about the time I was a little girl before my mammy and pappy leave me." 112 Church was another setting where oral tradition took place. It was where these songs were passed down, and it is where these bible verses were passed down as well.

Those who were enslaved in the Cherokee Nation could attend church with their Cherokee masters, but some individuals chose not to and would hold services by themselves. Some of the church services were located on plantations or woodland areas. Mrs. Chaney Richardson's reference to the brush arbor is an example of an outdoor church. These brush arbors were for meetings. Sometimes they are referenced as brush arbor meetings or camp meetings. Examples of this can be seen in the Illustrations 4.2 and 4.3 on pages.

Another Cherokee Freedwoman, Mrs. Betty Robertson, recalls a religious practice in the woodlands where Cherokees were present during her baptism upon her freedom from her Cherokee master. She wrote,

When we git to Fort Gibson they was a lot of negroes there, and they had a camp meeting and I was baptized. It was in the Grand River close to the ford, and winter time. Snow on the ground water was muddy and full of pieces of ice. The place was all woods and the Cherokees and the soldiers all come down to see the baptizing. ${ }^{113}$

\footnotetext{
${ }^{111}$ Minges, P., Black Indian Slave Narratives, (Winston-Salem, NC: John F. Blair, Publisher), 2004, pp. 4854.

112 Ibid.

${ }^{113}$ Baker, J., and Baker, T., The WPA Oklahoma Slave Narratives, (Norman, OK: University of Oklahoma Press), 1996, pp. 356-357.
} 
It was not until the 1870's that the first Cherokee Freedmen churches were established. The first Baptist church for the Cherokee Freedmen was founded by Reverend Fred Martin. ${ }^{114}$ More Freedmen Baptist churches grew from this church, and by 1888 there were nineteen Freedmen churches in the Cherokee Nation. ${ }^{115}$

\section{Musical Traditions Practiced by Cherokee Freedmen}

When it came to the practice of musical traditions, white slave holders did not allow Africans to participate in any of their own cultural practices because white slave holders thought their musical practices were too loud. However, in the Cherokee Nation, enslaved individuals "Were less restricted and held more trusted positions, and hence, their cultural practices were not as prohibited."116 African individuals, who were enslaved by white settlers, had to adapt to their environment and would have to adopt the use of other instruments. It could be argued that Cherokees allowed Africans to practice their own musical customs, for both African and Cherokee musical practices were similar, for they both played drums and at times both cultures incorporated dance. It has been said that the Cherokee Natives incorporated dance into their traditional adoption ceremonies, ${ }^{117}$ and adoption was the way in which many Cherokee Freedmen were granted citizenship in the Cherokee Nation.

\footnotetext{
${ }^{114}$ Littlefield, D., The Cherokee Freedmen from Emancipation to American Citizenship, (Westport, CT: Greenwood Press), 1978, pp. 58-60.

115 Ibid.

${ }^{116}$ Castro, J., Music Heard Deeply: Song and Ethnic Interaction in the Cherokee Ozarks, (Edmund, OK: University of Central Oklahoma) a thesis, 2008, p. 77.

117 "Journal of Antoine Bonnefoy," in Samuel Cole Williams, Early Travels in the Tennessee Country, 1540 1800, (Johnson City, TN: The Watauga Press), pp. 152-153. Cited in Halliburton, R. Red Over Black: Black Slavery among the Cherokee Indians (Westport, CT: Greenwood Press), 1977, pp. 193-194.
} 


\section{Education of the Cherokee Freedmen}

As stated earlier, Cherokee masters were not allowed to educate those who were enslaved, for it was illegal to do so. The education of the Cherokee Freedmen citizens in the Cherokee Nation began in 1869. Many Freedmen wanted their children to have a chance at education, but ultimately given their status, it was up to the Freedmen to make education possible for their children. This meant that the Freedmen were responsible for constructing and caring for their own institutions in which the Freedmen students were instructed. As it has been previously stated, there were Freedmen who held office as school administrators. The role of the administrator was to build and construct schools, thus building was never too much of an issue. Sometimes churches would double as school houses. Upon the construction of the school, the Cherokee board of education would assign an instructor and would pay the instructor from national funds. ${ }^{118}$ However there were some problems when it came to the education of Freedmen students in the Cherokee Nation.

One problem that prevented Freedmen from obtaining education was the attendance policy. Each school was required to reach a certain quota of student attendance. If there were not enough students in the district who could attend schools, then the schools could not stay open. The location of the schools was too far, thus preventing several Freedmen children from attending. There were some school districts that did not meet the enrollment requirement to qualify for a Cherokee public school. The attendance policy was a recurring problem when it came to the education of Freedmen students. However,

\footnotetext{
118 Littlefield, D., p.54
} 
there were a few other problems that surfaced when it came to the Freedmen's education. These problems were more serious than the attendance policy.

Another issue that deprived Freedmen students of education was expense. The Freedmen who did not meet the attendance policy qualifying for Cherokee public school ended up going to subscription schools, which were schools where students had to pay a monthly tuition to attend. The Freedmen were responsible for hiring their own instructor. The first Freedmen high school was a subscription school. It was not until 1890 that the Colored High School was built. There were several problems in the beginning. A recurring issue was enrollment requirement. Another reoccurring problem was cost. The tuition for students to attend the school was five dollars a month, which was why many students could not attend. There were also issues regarding the education the students received. The education was poor, and there were not enough supplies to go around. Enrollment later increased around 1901, but the education at that time revolved around an industrialized curriculum. Upon the selling of the school in 1910, the first problem of location returned. The only Freedmen students who lived in areas with high schools could attend high school. ${ }^{119}$ Cost was an important issue when it came to education, but the major problem that prevented the education of the Freedmen was citizenship.

\section{Possible Higher Education of Cherokee Freedmen and Cherokee Natives}

As previously stated, the education of the Cherokee Freedmen did not happen until 1869 in the Cherokee Nation. It is possible that Cherokee Freedmen were educated at Hampton Normal and Agricultural Institute along with Cherokees and Native Americans from differing Nations, which makes this information important for this study, for it is

119 Ibid 
another probable social channel between the Cherokee Freedmen, Cherokees, and Native Americans from differing Nations.

Hampton Normal and Agricultural Institute was established in Hampton, Virginia, in 1868, by General Samuel Chapman Armstrong. For its time, Hampton was originally a predominantly African-American institution. Due to the laws of Jim Crow upon emancipation in the American South, there was no distinction when it came to both African Americans and Native Americans. Both races were lumped together and labeled by white southerners as "colored." As a result both Native Americans and AfricanAmericans faced "biracial segregation, [and] southern Indians struggled to maintain their identities and establish institutions that expressed their identity." ${ }^{120}$ Even though Hampton was supposedly a form of higher education, it was not considered to be a college or a trade school.

Hampton was a normal school in that students who attended had little instruction, were older, and did not have the financial advantage of those who were attending universities. Hampton was also an institution where students, who were once enslaved, would go to gain certification to become a teacher at a common school. ${ }^{121}$ The core of Hampton's educational program was manual labor. Armstrong thought that manual labor routines should be taught, so that students would value hard work. He also held the same thought that early white settlers had of Native American students; he thought that AfricanAmerican students learning manual labor was the way to become "civilized" like the white man.

\footnotetext{
120 Perdue, T., "Native Americans, African Americans, and Jim Crow." In Indivisible: African-Native American Lives in the Americas. (Washington D.C.: Smithsonian Books), 2009, p.21

${ }^{121}$ Anderson, J., The Education of Blacks in the South 1860-1935. (Chapel Hill: North Carolina Press) 1988,
} 
The arrival of Native American students at Hampton in 1877 was not well accepted by citizens, students, and teachers had differing views on both Native Americans and African Americans being educated together. "Even before the Indians came to Hampton the Richmond Dispatch had complained about the proposed biracial program, claiming that Indians and blacks were distinct as blacks and whites." 122 Not only did citizens have an issue with Native American students coming to Hampton but teachers and students also had their share of concerns as well. However, more funding was given to the school by wealthy elites, who heard about this situation and cared about Native American education. ${ }^{123}$ Even Booker T. Washington, a well-known African-American educator was attending Hampton at that time, had a strong opinion of Native Americans attending the institution as well.

Washington and other African-American students saw the Native American students as intruders. When Washington was a student, he stated, "He and most of the student body believed that since Hampton was established for the benefit of the Negro, the Indian should not have been permitted to come in." 124 Ironically, Booker T. Washington later took on the position of becoming a house father for Native American male students at Hampton. He was nervous and concerned about this position. Washington explains in his autobiography Up From Slavery, "I knew the average Indian felt himself above the white man, and, of course, he felt himself far above the Negro, largely on account of the fact of

\footnotetext{
122 Lindsey, D., Indians at Hampton Institute 1877-1923, (Chicago, IL: University of Illinois press), 1995, p. 31 ${ }^{123}$ Edner J., and Reyhner J., American Indian Education, (OK: University of Oklahoma Press), 2004, pp. 132134.

${ }^{124}$ Washington, B., The Story of the Negro, The Rise of the Race From Slavery, (New York, NY: Doubleday and Company Inc.), 1909, p. 138.
} 
the Negro having submitting to slavery-a thing which the Indian would never do."125

Something important to note for this area of study, in regard to cultural identity is how

Booker T. Washington gained the trust and respect of the Native American students, and

how he gained an understanding of their cultural identity during his time as a house father.

Washington wrote,

The things that they disliked most, I think, were having their long hair cut, to give up wearing their blankets, and to cease smoking; but no white American ever thinks that any other race is wholly civilized until he wears the white man's clothes, eats the white man's food, speaks the white man's language, and professes the white man's religion. ${ }^{126}$

While Hampton Normal and Agricultural Institute was a place where both Native Americans and African Americans were educated together, the education of Cherokee

Freedmen was separate from Cherokee Natives in the Cherokee Nation.

\section{Adoption of the Cherokee Freedmen as Native Citizens in the Cherokee Nation}

Article nine in the Treaty of 1866 explains the adoption policy of the Cherokee Freedmen. After emancipation, the Cherokee Freedmen were required to be back in the Cherokee Nation and were given a six month timeframe for their return. However, there were Cherokee Freedmen who did not return in time and were not granted citizenship. Therefore, Freedmen who did not make it back into the Cherokee Nation on time were called "intruders." It seems this sort of labeling was also used by Cherokee Freedmen as a way to establish their Cherokee identity, for,

There was a variation in attitudes between freedmen who had lived their entire lives in the Indian nations (who called themselves "natives") and those African

\footnotetext{
${ }^{125}$ Washington, B., Up From Slavery, (New York, NY: Doubleday and Company Inc.), 1963, p. 68-69. 126 Ibid.
} 
Americans who emigrated to the Indian lands after they were opened up to settlement (referred to by the "native" freedmen as "state negroes). ${ }^{127}$

This labeling on behalf of Cherokee Freedmen was not only about establishing their own cultural identity, but it was also about elevating themselves to a higher social status.

Cherokee Freedmen did not like how compliant "state negroes" were to whites. Thus, Cherokee Freedmen did not associate with "state negroes" because they felt themselves to be of a higher status. ${ }^{128}$

Nevertheless, those who came back in time were offered land allotments. Cherokee Freedwoman Mrs. Chaney McNair wrote,

After the War was over, we colored folks all had to go back to prove up; tell where you come from, who you belong to, who you know, so we get our share of land. The government made a treaty with the Cherokees. If all the slaves come back, they give them Cherokee citizenship, but we had to be back by ` $66 .{ }^{129}$

Some of the Freedmen were told by their Cherokee masters that if they wanted, they could stay on their land and work for them upon emancipation. Cherokee Freedman Mrs. Betty Robertson commented on this and stated, "One day young master come to the cabins and say we all free and can't stay here less'n we want to go on working for him just like we'd been, for our feed and clothes." ${ }^{130}$ Mrs. Betty Robertson also commented on her and her husband receiving their land allotments in the Cherokee Nation but explains that her and her husband "was too old to care for the land ourselves." ${ }^{131}$ Even though this couple

\footnotetext{
127 Wickett, M., Contested Territory: Whites, Native Americans, and African Americans in Oklahoma, $1865-$ 1907, (Baton Rouge, LA: Louisiana State University Press), 2000, p.31.

128 Ibid.

${ }^{129}$ Minges, P. Black Indian Slave Narratives. (Winston-Salem, NC: John F. Blair, Publisher), 2004. p.45.

${ }^{130}$ Baker, J., and Baker, T., The WPA Oklahoma Slave Narratives, (Norman, OK: University of Oklahoma Press), 1996, p. 356

131 Ibid.
} 
decided not to live on their allotted land, there were still Cherokee Freedmen, who were trying to fight for their citizenship status in the Cherokee Nation.

The status of citizenship in the Cherokee Nation was a way in which the Cherokee Freedmen established their Cherokee identity. In 1879, Cherokee Freedman Joseph Rodgers wrote to the Cherokee Advocate, a newspaper from the Cherokee Nation, to explain how his citizenship status establishes his Cherokee identity. He stated,

Born and raised among these people, I don't know any other. The green hills and blooming prairies of this Nation look like home to me. The rippling of its pebbly bottom brooks made a music that delighted my infancy, and in my ear has lost its sweetness. I look around and I see Cherokees who in early days of my life were playmates in youth and early manhood, my companions, and now decrepitude of age steals upon me, will you not let me lie down and die your fellow citizen? ${ }^{132}$

Joseph Rodgers, along with many other Freedmen in the Cherokee Nation, lost their petition for Cherokee citizenship. This struggle in obtaining citizenship status is still a problem today for the descendants of Freedmen. However, this struggle to obtain citizenship status relies on a different issue. Instead of citizenship relying on the Cherokee Freedmen's adoption, their citizenship relies more on the Cherokee Nations 'blood quantum policy." This leads to the next chapter on the original political and voting rights of the Cherokee Freedmen and how they have changed over time.

${ }^{132}$ Rodgers, J., Cherokee Advocate. September 9, 1876, p. 3. 


\section{CHAPTER V}

\section{THE ORIGINAL RIGHTS OF CHEROKEE FREEDMEN AND HOW THEY}

\section{HAVE CHANGED}

Not only were the Cherokee Freedmen granted equal rights of citizenship and owning land, but they were also supposed to be given equal political rights, which meant that they could run for political offices and vote in tribal elections. This chapter will look at the political rights of the Cherokee Freedmen and will also note some Cherokee Freedmen political leaders. Looking at the political rights and notable Cherokee Freedmen political leaders is necessary for this research, because it further explains why the descendants of Freedmen should have the right to vote in tribal elections today. In addition, this chapter will give information on the Dawes Act and how the Dawes Commission dictated the rights the Cherokee Freedmen and Cherokees in the Cherokee Nation, which led to the dissolving of the Cherokee government. Finally, this chapter will conclude with the reestablishment of the Cherokee Nation.

\section{Cherokee Freedmen's Political Rights}

The Cherokee Freedmen should have had the same political rights as Native Cherokees, but this was not necessarily the case after the Treaty of 1866 was established. Cherokees did everything that they could to exclude the Cherokee Freedmen from voting and running for political office. Cherokees felt that politicians within the Cherokee Nation were supposed to be "civilized" people. An issue of the Cherokee Advocate notes 
how Cherokees did not want to have Freedmen within the Nation running for Cherokee National Council because they did not possess "the capacity to make laws for us."133 "Leaders in Indian Territory appealed to voters on racial grounds in an effort to restrict the political rights of the freedmen."134This act not only happened within the Cherokee Nation, but it happened in other Native Nations as well, for Native Americans started to realize that there were more Freedmen than full-blooded Natives in Indian Territory. The Freedmen in the Nation were influenced heavily on how to vote by Cherokee Natives, even though they should have possessed the equal right to make their own decisions when it came to politics. There were different ways in which the Cherokees made this happen.

One tactic that Cherokees used to have Cherokee Freedmen sway their votes is flattery. "It was not popular to advocate for the equality of the freedmen, and the Cherokee politicians were too shrewd to do so." However, this is something that Cherokee politicians did to obtain more votes, for they would have the Freedmen's votes. ${ }^{135}$ Another tactic that was used to acquire the Freedmen vote was intimidation. Some of the Freedmen indicated that this intimidation came from the former Confederate Cherokees. ${ }^{136}$ "They alleged that the old Confederate faction of the tribe used to get drunk and visit black settlements in squads to intimidate the ex-slaves into voting for their candidate. If the Freedmen refused, the Indians would shoot at them."137 It is possible that in a final effort, before elections were held, Cherokee politicians would

\footnotetext{
${ }^{133}$ Cherokee Advocate, 2 (46), July 30, 1879.

134 Wickett, M., Contested Territory: Whites, Native Americans, and African Americans in Oklahoma 18651907, (Baton Rouge, LA: Louisiana State University Press), 2000, p. 172.

135 Littlefield, D., pp. 63-64.

136 Ibid.

${ }^{137}$ Wickett, M., p.173.
} 
bribe the Freedmen for their vote. ${ }^{138}$ Although the Freedmen voted in Cherokee Nation elections, were their votes counted? If so, were the votes accurate, or were they changed, so that competing politicians could obtain more votes? W.E.B. DuBois surveyed college educated African-Americans in his work The College Bred Negro.

DuBois asked questions relating to problems stemming from African-American presence in the South. Two of the questions were, "Do you usually vote?" and "Is your vote usually counted?" Someone from Indian Territory answered and stated that there was no election in response to the question about going to vote, but in regards to the question of votes being counted, they stated, "We colored landowners have an organization to protect our interest." 139 The organization they are speaking of is known as the Negro Voters Protection Leagues. These protection leagues existed in Oklahoma Territory and in Indian Territory, but the leagues merged together after Oklahoma became an official state. These leagues were responsible for appearing "at the local level to protect black voters in exercising their right to vote." ${ }^{140}$ Not only did the leagues assist in the protection of voting rights, but they also assisted in the protection of those who wanted to hold a political office.

When it came to Freedmen wanting to run for a political office in the Cherokee Nation, the odds of being elected were slim. It was not until 1875 when the first Freedman was elected as a counselor for the Cherokee National Council. The first Freedman elected, Joseph Brown, was elected in the Tahlequah District of Cherokee

\footnotetext{
138 The Vinita Weekly Chieftain, 11(48), July 30, 1903.

${ }^{139}$ DuBois, W.E.B., The College Bred Negro, (Atlanta, GA: Atlanta University Press), 1900, p. 87.

140 Wickett, M., p.183.
} 
Indian Territory. ${ }^{141}$ In 1893 Joseph "Stick" Ross was elected into the Tahlequah District as a counselor for the Cherokee National Council. ${ }^{142}$ Tahlequah is located in what is now Oklahoma. Additionally, it is also where the capitol of the Cherokee Nation is located. It is important to note that Joseph "Stick" Ross was owned by Principal Chief John Ross. During enslavement, he helped to build the Cherokee Capitol building in the Cherokee Nation, and he encouraged other Freedmen in the Cherokee Nation to run for Cherokee National Council as well as helping Freedmen in their fight for citizenship rights. ${ }^{143}$ In 1895, Cherokee Freedman Ned Irons was elected to the Cherokee National Council in the Tahlequah District. There were three other Freedmen who were elected to the Cherokee Nation Council. Two of the Freedmen were elected in the Illinois District. Frank Vann was elected in the year of 1887, and Samuel Stidham was elected in 1895. The third Freedman elected for Cherokee National Council in 1889 was Jerry Alberty. He was elected in the Cooweescoowee District, which is also located in Oklahoma. ${ }^{144}$ Even though these Freedmen were successful in securing a political office, there were several Freedmen who were not as successful. Instead, most of the Freedmen involvement in the Cherokee Nation was community based. Thus, Freedmen held positions as jurors, guards, managers for estates, and school administrators. The main obligation of a school administrator was to build schools and to maintain them. ${ }^{145}$

\footnotetext{
141 Littlefield, D., p. 64

142 Jackson, T., "Stick Ross: 'Tahlequah pioneer and civic leader,'" Cherokee Phoenix, March 3, 2011, http://www.cherokeephoenix.org/25610/Article.aspx viewed on September 15, 2013.

143 Ibid.

144 Starr, E., History of the Cherokee Indians, (Cherokee NC: Cherokee Press), 1921, pp. 277-279 and 282283.

145 Littlefield, D., p.65.
} 


\section{How Cherokee Identity and Tribal Citizenship was Redefined for the Cherokee Freedmen}

The Dawes Age began when Henry L. Dawes, a Massachusetts senator proposed a bill for what he thought would be for the betterment of Native people in regards to land ownership and citizenship as United States citizens. Senator Dawes wanted to rid Native Americans of their reservations, so tribal authority would no longer exist. Thus, Natives would not have the authority to dictate citizenship and land ownership of their nations. Soon after the passing of the Dawes Act in 1887, the Dawes Commission entered Indian Territory and designated citizenship and land allotments. ${ }^{146}$

The dictation of citizenship was recorded on two different rolls. One roll was the Cherokee by blood roll, which was the roll that Cherokee citizens were listed on as well as whites who intermarried with Cherokee citizens. The other roll was known as the Freedmen's roll. This roll was specifically for Freedmen. The Freedmen's roll was for those who did not possess any Cherokee blood. Thus, they were not considered Cherokee. The way in which the Dawes Commission documented this information was not consistent. The Dawes Commission held interviews with everyone who resided in the Cherokee Nation, but depending on which member of the Dawes Commission conducted the interview was how identity was documented.

There were some members of the commission who took the documentation seriously and would take note of the self-identification of individuals in the Cherokee Nation. These individuals were documented accordingly even if they were people of mixed Native and African descent. There were also members of the Dawes Commission

\footnotetext{
${ }^{146}$ Wickett, M., p.51.
} 
who did not listen to how the people in these interviews identified themselves. Instead, people's identity would be dictated based upon their appearance. Some people were documented as not having any Cherokee descent, because their skin tone was considered to be "too dark," but in reality they might have actually been of Cherokee descent. This raises the question of "What does a Cherokee look like?" In most cases regarding identity, things are not always as they appear, so physiology should not be seen as hard evidence on how someone is identified. Even though physiology should not be used to articulate someone's identity, this is what happened when the Dawes Rolls were documented.

The most important part to note regarding the Dawes Rolls is, that the documents were used to take over the Cherokees' land. The blood quantum that was recorded had nothing to do with defining who was authentically a Cherokee citizen. "It was, rather a device to determine which Cherokee citizens would be the first to lose their land to white buyers." ${ }^{147}$ Ultimately, all of this noting and assigning of land was about greed and control. White settlers wanted to control who lived on the land as well as who had rights to own land. What land was left was sold to whoever wanted to purchase it. "More than 90 million acres — nearly two-thirds of reservation land—were taken from tribes and given to settlers as 'surplus,' most often without compensation to the tribes." ${ }^{\text {148 }}$ The Curtis Act was an amendment added to the Dawes Act in 1889, and it dissolved the Cherokee government in 1906.

\footnotetext{
${ }^{147}$ Littlefield, D., "The Cherokee Freedmen: Cherokee Citizens by Treaty". Indivisible African-Native Lives in the Americas. 2009. pp.130-131.

${ }^{148}$ National Congress of American Indians. An Introduction to Indians in the United States, p.3. http://www.ncai.org/about-tribes/Indians_101.pdf viewed on February 17, 2014.
} 


\section{The Reestablishment of the Cherokee Nation}

The federal government's enacting of the Principal Chiefs Act in 1971, allowed the Cherokee Nation, to elect their own Principal Chief. ${ }^{149}$ The Principal Chiefs Act is an act "To approve each of the Five Civilized Tribes of Oklahoma to popularly select their principal officer, and for other purposes." "150 Approved on October 22, 1970, Cherokee citizens were given "blue cards" as proof of citizenship. Even the Cherokee Freedmen and their descendants' citizenship status as equal citizens was reestablished, for they were issued "blue cards" because of the adoption policy from the Treaty of 1866. An example of a "blue card" can be seen in Illustration 5.1 on page 116.

In 1975, an election was held to approve the new constitution. Article III of this constitution states that those who are enrollees of the Dawes Rolls and their descendants are deemed citizens of the Cherokee Nation. ${ }^{151}$ The adoption policy was in effect until 1983 when the Cherokee Nation required CDIB's Certificate Degree of Indian Blood cards for citizenship. ${ }^{152}$ An example of the CDIB can be seen in Illustration 5.2. During this time, the Cherokee Nation Tribal Council approved an act requiring all Cherokee citizens to provide a CDIB card, which would prove their degree of Cherokee blood. ${ }^{153}$ This had a negative effect on the citizenship status of the Cherokee Freedmen because few Freedmen had their Cherokee blood quantum documented on these rolls. Many of the Freedmen were listed on the Freedmen's Roll, which meant that they did not possess

\footnotetext{
${ }^{149}$ Chavez, W., “Cherokee Nation/Freedmen Timeline," Cherokee Phoenix, 2006, 30 (8), p.4.

${ }^{150}$ Kappler, C., INDIAN AFFAIRS: LAWS AND TREATIES, Vols. VI, (Washington: Government Printing Office), 1904, pp. 1208-1209.

${ }^{151}$ Cherokee Nation, Constitution Convention Commission Report to the Cherokee People Regarding Upcoming Votes on the Constitution, 1999, p.3.

152 CDIB cards are also known as "white cards."

${ }^{153}$ Chavez, W., "Cherokee Nation/Freedmen Timeline," Cherokee Phoenix, 2006, 30 (8), p. 4.
} 
Cherokee blood. Thus, the Cherokee Freedmen could not be issued CDIB's by the Bureau of Indian Affairs BIA.

The BIA operates through four offices. These offices are: The Office of Indian Services, Justice Services, Trust Services, and Field Operations. In particular, the Division of Tribal Government in the Office of Indian Services is responsible for distributing CDIBs. Due to the fact that Cherokee Freedmen did not meet this criteria for citizenship status, their citizenship status was revoked. The BIA emphasized to the Cherokee Nation that the Cherokee Constitution and the Treaty of 1866 granted Cherokee Freedmen and their descendants' citizenship and voting rights. ${ }^{154}$ From this occurrence stemmed the first of several court cases in the descendants of Freedmen's fight for tribal citizenship status. However, more on these cases will be discussed in the findings of this research.

\section{The Benefits Freedmen Descendants Have Lost By Not Holding Tribal Citizenship Status in the Cherokee Nation}

Through all of this research on the Cherokee Freedmen and their descendants' fight for tribal citizenship status, it is hard not to wonder what the benefits are of holding tribal citizenship status in the Cherokee Nation. Benefits in this research are defined by what is gained by being a tribal citizen. What sort of rights and privileges are the Freedmen descendants gaining with tribal citizenship status? Due to their disenfranchisement, what sort of benefits do the Freedmen descendants argue are important?

\footnotetext{
${ }^{154}$ Ibid.
} 
Voting can be seen as one of the many benefits and privileges of citizenship in the Cherokee Nation. However, citizens must be 18 or older, registered voters, and possess a CDIB and a Cherokee Nation citizenship card to be eligible to vote. ${ }^{155}$ Ultimately, each member of the Cherokee Nation want to have their vote count when it comes to who is elected as a tribal official. In addition to the tribal officials who are elected, citizens like having their vote count when it comes to new laws and amendments added to the constitution. Unfortunately, many of the descendants of Freedmen are ineligible to vote, for they do not possess a CDIB, which is required to vote.

Another benefit to citizenship in the Cherokee Nation are health benefits such as vision, dental, and medical. Health benefits are granted through the BIA or Indian Health Service. There are eligibility requirements that must be met to acquire these health benefits. Some of these requirements are based upon financial need, age, and disability. ${ }^{156}$ There are Freedmen descendants who qualified for health benefits because they met the requirements. However, because they are no longer tribal citizens, descendants are automatically ineligible for these health benefits.

There are some educational benefits, since the Cherokee Nation has scholarships in which citizens can apply. There are also other tribal scholarships that citizens can apply for outside the Cherokee Nation, but there are no guarantees that every citizen who applies will obtain one of these scholarships. ${ }^{157}$ Just because a person applies for a scholarship, it does not mean that they will obtain the scholarship. These scholarships are

\footnotetext{
${ }^{155}$ Cherokee Nation, "Frequently Asked Questions," Last modified 2014, viewed on March 26, 2014. http://www.cherokee.org/Services/TribalCitizenship/FrequentlyAskedQuestions.aspx .

${ }^{156}$ Ibid.

${ }^{157}$ Ibid.
} 
just like many other scholarship in that they are competitive. Nevertheless, the problem that still arises is the lack of tribal citizenship status. Without holding tribal citizenship status, Freedmen descendants cannot be in the running for these scholarships.

Additionally, there are tribal colleges that citizens can attend due to their tribal citizenship status, but again, this status is needed to attend one of these institutions.

Arguably, tribal citizenship status is a major benefit of being a Cherokee citizen. This status is shown through identification. Today, the "blue card" otherwise known as the Cherokee Nation citizenship card is only part of the identification needed for tribal citizenship. The other identification required is the "white card" otherwise known as the Certificate Degree of Indian Blood. Some tribal members of the Cherokee Nation have both of these cards of identification, but they are separate. For convenience, tribal members can choose to have both cards made into one card covering the front and back. Additionally, the "blue card" now has the citizen's picture on it. Cherokee Nation Principal Chief Bill John Baker said. "Producing a government-issued, photo ID helps to instill a greater sense of pride in our people and decrease the possibility of fraud or misuse of the traditional "blue card." 158 An example of a current "blue card" can be seen in Illustration 5.3. When it comes to the descendants of the Cherokee Freedmen, citizenship status is something they have had to defend since it has been revoked since 1983. Many descendants of Freedmen are ineligible for tribal citizenship status because they do not possess a CDIB.

\footnotetext{
158 Cherokee Nation, "Tribal Citizenship," Last modified 2014, viewed on March 26, 2014, http://www.cherokee.org/Services/TribalCitizenship/FrequentlyAskedQuestions.aspx. Quote given by Principal Chief John Baker.
} 
There are other benefits that the descendants of Freedmen lose by not holding tribal citizenship status. However, these benefits were not mentioned by Freedmen descendants in this research. An example of this is owning land. There are two different types of land that can be owned, but for a Freedmen descendant to own any sort of land in the Cherokee Nation, they must first have tribal citizenship status. Another benefit is employment opportunities. Cherokee citizens have an opportunity to work for the Cherokee Nation. Employment in the Cherokee Nation comes with its own benefits like paid education and affordable health insurance. These benefits of employment and others were found in an advertisement from the Cherokee Phoenix, which can be seen in Illustration 5.4. Additionally, there are tribal discounts. Certain businesses will give tribal discounts if citizens present their CDIB card. An example of this was found in an advertisement from the Cherokee Phoenix, which can be seen in Illustration 5.5. Consequently, descendants of Freedmen do not possess CDIB's for they are not considered to have Cherokee blood.

\section{Tribal Health Benefits Aren't Always the Best Benefits}

In addition to Freedmen descendants worrying about losing their tribal health benefits, it is important to address how tribal health benefits are greatly misunderstood. Although Native Americans are entitled to free health care at tribal facilities, this does not mean it is the best health care. This is a major misconception that many people have because,

Most Indian health facilities do not offer a full array of services. When patients need major surgery or cancer treatments, for example, they are referred to 
specialists outside of Indian lands. At least two-thirds of those referral claims are rejected. ${ }^{159}$

Because referral claims are often rejected, Native Americans have less access to health care. Also, Native Americans who need surgery or cancer treatments, for instance, will have to pay for it themselves or go without the care they need.

\section{Why Do People want to be Native?}

Those who are not able to prove their ancestry for tribal citizenship status and are still trying to claim their authenticity as tribal citizens are called wannabes. Why would anyone want to be Native when they are not able to prove their authenticity, or have not lived in a Native environment? There are several answers to this question, starting with how people think they will gain some sort of economic benefit from tribal citizenship status such as government and casino checks, scholarships, and not having to pay taxes.

Another reason why people want to be Native is because of their romanticism of Native culture. Non-Natives romanticize Native people as possessing spiritual mysticism and being one with nature, bravery, and independence. Additionally, non-Natives wannabe Native because they are bored with their own lives. ${ }^{160}$ In relation to this study, there were several African-Americans who wanted to claim Native American identity because they did not want to be treated poorly by whites. ${ }^{161}$ Sadly, there are African-

\footnotetext{
159 Vestal, C., "Affordable Care Act a hard sell for Native Americans," USA Today, October 15, 2013, viewed on July 29, 2014, http://www.usatoday.com/story/news/nation/2013/10/15/stateline-obamacare-nativeamericans/2986747/.

${ }^{160}$ La Vere, D., "Of Wannabes and Indians," 2011, viewed on August 1, 2014, http://davidlavere.com/ofwannabes-and-indians/.

${ }^{161}$ Gates, H., African American Lives, PBS Home Video, Recorded 2006, Paramount, 2006, DVD.
} 
Americans who want to trace their Native ancestry, but worry about being called "race traitors." $" 162$

${ }^{162}$ Sturm, C., "Blood Politics, Racial Classification, and the Cherokee National Identity: The Trials and Tribulations of the Cherokee Freedmen," American Indian Quarterly, 22(1/2), (Winter-Spring) 1998, p.250. 


\section{CHAPTER VI}

\section{FINDINGS}

The types of literature investigated for this research was based on the following text: several articles of the Cherokee Phoenix, opinions that Cherokee citizens have written to the Cherokee Phoenix regarding the current issues of citizenship, legal documents from court cases of the descendants of Freedmen. Also, other Native publications outside of the Cherokee Nation, and various news articles published outside of the Cherokee Nation, including magazine articles from Ebony and Diverse, and This Land, regarding the descendants of Freedmen's fight for tribal citizenship status have been taken into account. The qualitative discourse analysis of this literature was categorized into seven themes. Those are Allies of descendants of Freedmen, Tribal Sovereignty, Remarks Constructed by Racial Bias, Self-Identification of the descendants

of Freedmen, Comments in Relation to Tribal Citizenship Benefits, Identity Crisis of the descendants of Freedmen, and Traditionalism of the Cherokee Nation.

\section{Allies of Descendants of Freedmen}

Since 1988, genealogist David Cornsilk, has been an advocate for the Cherokee Freedmen descendants. At first, Cornsilk agreed with most Cherokees in the Cherokee Nation when it came to citizenship and voting rights of the Freedmen descendants, but his judgments changed based on a specific incident. Cornsilk recalls seeing during the Cherokee election of 1983 an old Black man who stood in a long line in the hot sun 
waiting for his turn to vote. When the old man got to the front of the line, his voter registration card was put to the side, and he was told "We don't let you people vote here anymore."163 The Cherokee Freedmen and their descendants were barred from voting in this election due to the fact that each member of the Cherokee Nation was required to have a CDIB card. Cornsilk was disgusted by this incident. While working at the Cherokee Nation's department of Tribal Registration, Cornsilk said, "Part of my job was to deal with Freedmen applicants," and "I started reading their histories, and I came to the realization that we really screwed these people." 164 This motivated Cornsilk to help descendants of Freedmen fight for their tribal citizenship status. What is so remarkable about Cornsilk is that he quit one of his jobs to help the descendants of Freedmen. He broke his lease on his apartment and lived in his car, and he also stepped down from his tribal employment. Cornsilk does not see the Freedmen as Freedmen, for he says "The Freedmen died a long time ago. You are not Freedmen. You are Cherokee, and it is time that you begin to recognize who you are."165

Cornsilk was the Petitioner for Cherokee Freedman Lucy Allen in her case for tribal citizenship against the Cherokee Nation. This case was held at the Judicial Appeals Traditional, which is also known as tribal court. Cornsilk helped Lucy Allen win her case for citizenship in the Cherokee Nation. This case focused on the 1975 Constitution of the Cherokee Nation and the word choice that was used in the Cherokee Nation's 1975 Constitution. In a legal document filed on March 7 2006, much information on citizenship was given in Article III of the Cherokee Constitution of 1975,

\footnotetext{
163 Samuels, A., “What Does Indian Blood Look Like” Ebony. 2008, p. 97.

164 Barbery, M. "From One Fire," This Land, 4 (10). May 15, 2013.

165 Ibid.
} 
In subsection (B), the legislation requires proof of lineage 'by blood.' This too is contrary to the plain language of Article III, which lacks any 'blood' requirement whatsoever. The Constitution only requires proof of lineage from a 'citizen.' It does not require proof of Cherokee or Indian blood" and "Providing proof of Cherokee blood is clearly not the only way to prove membership. In fact, Article III expressly mentions the Shawnee and Delaware, who possess some Indian blood, but not Cherokee blood. The Shawnee and Delaware are not citizens 'by blood' of the Cherokee Nation. ${ }^{166}$

The Cherokee Nations' response to the Article III argument presented was that the Cherokee Freedmen are not even mentioned in Article III for citizenship and therefore are not considered citizens. Allen and Cornsilks' response to Article III is that it does not mention that Cherokee citizens have to be Cherokees by blood.

An interesting finding pulled from this legal document are these questions about Article III, “Are both the 'Cherokees by blood' and the 'Cherokee Freedmen' included by silence? If not, can one group be included by silence while the other is excluded by silence?" 167 Another finding that is important when it comes to the word choice of this Constitution of the Cherokee Nation is,

The individuals who drafted the 1975 Constitution were well-educated and some were attorneys. They were familiar with Cherokee Nation legal history when they included the direct reference to the Dawes Rolls in the 1975 Constitution, they knew the Cherokee Freedmen were included in that document." and "These individuals were also familiar with Cherokee history under the 1839 Constitution, the Cherokee Nation's treaties and agreements, and the allotment process. The authors could not have been unaware of the citizenship status of Cherokee Freedmen. At that point in time, the Cherokee Freedmen had been legal citizens of the Cherokee Nation for 110 years. ${ }^{168}$

All of these findings from this particular case are important, for they lay a solid foundation in the descendants of Freedmen's fight for tribal citizenship because of the

\footnotetext{
${ }^{166}$ Lucy Allen vs. Cherokee Nation, The Judicial Appeals Tribunal of the Cherokee Nation, Filed March 7, 2006, p. 5.

167 Ibid., p.12.

168 Ibid., p.15.
} 
fact that this case was successful. Those Freedmen who tried to petition their citizenship with the Cherokee Nation prior to this case, were often dismissed.

Another ally is Jon Velie. He is an Indian Law expert and he also represents the Cherokee Freedmen. ${ }^{169}$ On August 7, 2003, Velie commented on the May 24, 2003, election, and stated, "The BIA decision to recognize an election that forbid the participation of approximately 25,000 voters based on a racist policy is a giant leap in the worst direction." 170 In June 2003,

A group of Cherokee Freedmen allied with four former elected officials who lost in their bids for re-election, contact the BIA to protest the May $24^{\text {th }}$ general election. The group contends that the citizenship rights of 'Black Cherokees' are protected by the Treaty of 1866, and 25,000 'Black Cherokees' were not allowed to vote. ${ }^{171}$

The Treaty of 1866 is the Freedmen descendants' main argument in their case against the Cherokee Nation. In addition to the Treaty of 1866 being the main argument, the Thirteenth Amendment of the United States Constitution aids in the Freedmen's fight for tribal citizenship status. In another legal document filed on March $26^{\text {th }}$ information was found on the argument of the Thirteenth Amendment and states,

The Thirteenth Amendment rights at issue here are public rights guaranteed to all citizens of the United States and not merely private rights applying only to the Freedmen. While other classes of citizens have other means to enforce these public rights, unless this case moves forward, the Thirteenth Amendment will continue to be nothing more than an empty promise to the Freedmen. ${ }^{172}$

\footnotetext{
169 The Associated Press, "Tribe Slave Descendants Face Uncertainty," Velie Law Firm Newsroom, March 4, 2006, viewed on July 31, 2014, http://www.velielaw.com/showArticle.asp?articleid=29 .

170 Velie, J., "Bureau of Indian Affairs Recognizes Cherokee Election Although Black Citizens Forbidden Right to Vote," Velie \& Velie Attorneys at Law Press Release, August 7, 2003, p. 2.

${ }^{171}$ Chavez, W., "Cherokee Nation/Freedmen Timeline," Cherokee Phoenix, August 2006, 30(8), p. 4.

172 Marilyn Vann, et al. v. Department of the Interior, et al. Appeal From the United States District Court For the District of Columbia, March 26, 2012, p. 47.
} 
Just as Cornsilk and Velie made claims, Congresswoman Diane Watson also makes claims on behalf of the descendants of Freedmen, which are the Treaty of 1866 and the Cherokee Nations' Constitution. ${ }^{173}$

Watson could be seen as an ally for the descendants of the Freedmen, but arguably the findings have shown that she does not seem to respect the Cherokee Nation due to her lack of knowledge on tribal sovereignty and self-determination. Her approach in helping the descendants of Freedmen regain their citizenship was to push bill HR 2824. This bill would cut ties between the U.S. Government and the Cherokee Nation and would also cut federal funding until the citizenship of the descendants of Freedmen was returned.

Arguably, John Stremlau, who is the vice president for Peace Programs at The Carter Center in Atlanta, could be seen as an ally to the Freedmen descendants. He observed the Cherokee Nations' rerun election for Chief between current Principal Chief Chad Smith and opposing candidate Bill John Baker on September 24, 2011, to ensure it was a fair election. ${ }^{174}$

\section{Tribal Sovereignty}

There were several opinions in the Talking Circles section of the Cherokee Phoenix on tribal sovereignty. There was a special election that took place in the fall of 2006, which was a re-election from the election that took place on March 3, 2003, to vote on an amendment of the Cherokee Constitution to make it a requirement that all citizens

\footnotetext{
173 Good Voice, C. "Watson seeks funding cut to Cherokee Nation," Cherokee Phoenix, September 2007, Front page.

174 Stremlau, J., "Black Cherokees exercise hard-won right to vote," from CNN News Source, Updated October 19, 2011 pp. 1-2 viewed on June 11, 2013, www.cnn.com.
} 
of the Cherokee Nation have Indian blood for tribal citizenship. ${ }^{175}$ One citizen was happy about the special election because the Cherokee citizens were "finally elected to make a move to protect our sovereignty by excluding the Freedmen from benefits afforded to our people." ${ }^{\prime 16}$ During the election of 2003, the Freedmen descendants were excluded from voting in the election due to the fact that they did not meet the Indian blood policy for tribal citizenship.

There were several comments made about Congresswoman Diane Watson. Quite a few citizens have strong opinions against Congresswoman Diane Watson. Not only because she claims she is a descendant of Pocahontas but also because of her ignorance regarding tribal sovereignty. ${ }^{177}$ Some citizens comment on the fact that Watson does not understand that sovereign nations have the right to determine their own citizenship. ${ }^{178}$ "When asked if she could even define tribal sovereignty or self-determination, Watson insisted that was irrelevant." 179 While Congresswoman Watson has been an ally to the descendants of Freedmen, Congress and the federal government should not get involved in intertribal issues and let the Cherokee Nation resolve their own issues. President Barack Obama also comments on this issue and stated, "Tribal sovereignty must mean that the place to resolve intertribal disputes is the tribe itself." He also stated, "Our nation has learned with tragic results that federal intervention in internal matters of Indian tribes is rarely productive ... This is not a legacy we want to continue." 180

\footnotetext{
${ }^{175}$ Chavez, W., "BIA to CN: special election not approved," Cherokee Phoenix, May 2007, p. A-2.

176 Collins, L., "Happy about special election," Cherokee Phoenix, May 2007, p. A-4.

177 Hix, B., "A little scared of Watson's Ignorance," Cherokee Phoenix, October 2007, p. A-4.

178 Shelton, P., "An Immodest Proposal," Cherokee Phoenix, October 2007, p. A-4.

179 Ross, G., "Facts don't interest Watson," Cherokee Phoenix, November 2007, p. A-4.

180 “Obama: Let courts decide Freedmen issue," Sho-Ban News, May 14, 2008, p. 4.
} 
Principal Chief Chad Smith spoke about tribal sovereignty in an article of the Cherokee Phoenix. He wrote "I was particularly pleased with that the Cherokee people voted by a 2 to 1 margin to affirm our decision of four years ago to keep the BIA and the people in Washington, DC out of our Constitutional process." ${ }^{181}$ In this article Chief Smith also give examples as to why the Cherokee Nation should be sovereign. Some of the examples he gives are, the Trail of Tears and land allotment.

Julianne Jennings, a student from Arizona State University wrote about tribal sovereignty on Indian Country Today Media Network.com and explained,

The Cherokee are sovereign having the right to self-govern, including varying eligibility criteria for membership without interference from the outside. Let's not forget that sovereignty begins with the moral and legal obligations, tempered in an ethical pursuit to right the wrongs imposed upon them and others through treaties skewed to benefit the United States to the detriment of all 'civilized people. $^{182}$

\section{Remarks Constructed by Racial Bias Found in Talking Circles}

Looking at the 2006-2007 issues of the Cherokee Phoenix, the opinions section also known as Talking Circles, many citizens in the Cherokee Nation voiced their opinions on the tribal citizenship status of the descendants of Freedmen. Some of the Cherokee citizens come off as having a racial bias when it comes to tribal citizenship status of the descendants of Freedmen. One citizen remarks on how California Congresswoman Diane Watson threatened to strip the Cherokee Nation from federal funding if the Cherokee Nation does not grant citizenship to descendants of Freedmen,

\footnotetext{
${ }^{181}$ Smith, C., "All should be supporting sovereignty," Cherokee Phoenix, August 2007, p. A-4.

182 Jennings, J., "Cherokee Freedmen: One Year Later," Indian Country Today Media Network.com, January 31, 2012, pp.1-2, viewed on July 13, 2013

http://www.indiancountrytodaymedianetwork.com/ict sbs/Cherokee-freedm .
} 
who do not meet the blood policy for citizenship, and stated "I believe Watson's real objective is to punish the tribe because the Cherokees will not accept black people as Indians." "183 It should be understood that this particular citizen was upset about the federal government trying to step in and dictate the Cherokee Nations' status for citizenship.

The same citizen wrote an opinion on identity in September of 2007 and stated "I am three-quarters Cherokee, and there is no way I want to be a part of a tribe that has African-Americans as ineligible Cherokee citizens. The Cherokee Nation should be compromised of Cherokee people." 184 This citizen was responding to the "invalid claim" made by the Freedmen descendants on how their citizenship should be based on the Treaty of 1866, and stated that the Treaty of 1866 was forced upon the Cherokee Nation. Thus, the citizenship rests solely on the idea of blood quantum.

\section{Self-Identification of the Freedmen Descendants}

Marilyn Vann, who is the President of the descendants of Freedmen Organization, has shown evidence of how the identity of the Cherokee Freedmen and their descendants' identity is a double identity. The Freedmen descendants' case for citizenship 'began in 2003 after Cherokee Freedwoman Marilyn Vann applied for Cherokee citizenship, only to be rejected and thereby denied the right to vote in a tribal election. She filed suit, alleging that the Interior Department has failed in its' duty to enforce the Treaty of 1866." 185 Findings of this were shown in an article of the Cherokee Phoenix, an article from Diverse magazine, and the press release from Jon Velie's law firm. In one article

\footnotetext{
${ }^{183}$ Washington, O., "CN needs real sovereignty," Cherokee Phoenix. June 2007, p. A-4.

${ }^{184}$ Washington, O., "Identity is the higher priority," Cherokee Phoenix. September 2007, p. A-4.

${ }^{185}$ Monet, J., "Freedmen Present Case: D.C. Circuit hears oral arguments in Cherokee Freedmen treaty dispute; Cherokee Nation repeats call to dismiss the case," Indian Country Today, 2(42) November 7, 2012, pp. 12-13.
} 
from the Cherokee Phoenix, Marilyn Vann wrote "It is my duty to stand up for my ancestors. I will not stand by and watch others attempt to strip me of who I am." ${ }^{186}$ In Diverse magazine Vann stated, "All people in this country of African descent do not have the same history. Black people whose ancestors were enslaved based on tribal government policies don't." ${ }^{187}$ In the press release from Jon Velie's law firm, Vann stated,

The stripping of my vote and identity as a Cherokee fills my heart with sorrow and rage. How can the United States recognize my Tribe's government and fund millions of dollars of aid to it, when it denies me my most precious asset, the right to vote for my elected officials and decide major Constitutional reform? I not only feel less of a Cherokee today, but less of an American. ${ }^{188}$

Another citizen J.D. Pennington commented in the Cherokee Phoenix on his double identity and stated "'I'm proud of being Indian,' Pennington said. 'I'm proud of all of my heritages. And being Black- I have no problem with being Black. Most people see me as being Black." ${ }^{189}$ Pennington also spoke about learning history from elders and stated, "In the Indian community they pass a lot of things down - from the elders to the younger ones," and “A lot of (the history) is oral. If you don't learn it now, you'll learn it from someone who just thinks they're Indian." ${ }^{190}$ It is important to note that Pennington is in support of the Cherokee Nations' requirements for citizenship. He feels that "It's

\footnotetext{
${ }^{186}$ Chavez, W., "Freedmen file injunction to halt constitutional change," Cherokee Phoenix, June 2007, p. A-2.

${ }^{187}$ Cooper, K., “Citizenship Deferred: Descendants of Cherokee Slaves Known as Freedmen, Are Still Fighting for Voting Rights and Basic Services," Diverse, 2011, pp. 12-13.

188 Velie, J., "Bureau of Indian Affairs Recognizes Cherokee Election Although Black Citizens Forbidden Right to Vote," Velie \& Velie Attorneys at Law Press Release, August 7, 2003, p. 2.

189 Good Voice, C., "Perspectives differ on Cherokee vote," Cherokee Phoenix, April 2007, p. A-2. 190 lbid.
} 
their sovereign right as an Indian nation, and if they don't, then non-Indians will take resources from the 'real Indians." "191

John Hope Franklin illuminates the concept of double identity in regard to the descendants of Freedmen in The New York Times from a historical perspective, for his familial lineage connects through mixed-race Native American and African American identity. Franklin explains growing up in Oklahoma,

Where blacks and Indians were 'very much involved with each other, not only in terms of friendship, but in terms of marriage.' And 'it is perfectly absurd to talk about dividing Indians and blacks. Any Indians who speak in exclusionary terms do not represent the historic interests or the historic relationships of Indians and blacks. ${ }^{192}$

Cherokee Freedmen descendant Kenneth Cooper, who is also a journalist, traced his family ancestry and found that he was a descendant of Thomas Still. Cooper found that Thomas Still was his great-great-great grandfather and that he walked the Trail of Tears. Cooper stated, “At least one of my ancestors was on the Trail of Tears---by double compulsion. The U.S. Troops compelled his mixed-white Cherokee owner, who compelled my ancestor to come and, presumably, provide for his needs."193

Cherokee citizen Heather Williams's article, “Let Cherokees decide who’s Cherokee," was reprinted in the Cherokee Phoenix. In this article Williams explains that she is a descendant of both the Cherokee Freedmen and Cherokee Natives. Williams also

\footnotetext{
191 Ibid.

192 Staples, B., "When Racial Discrimination Is Not Just Black and White," The New York Times, September 12, 2003, pp. 2-3, viewed on June 15, 2013, http://www.nytimes.com/2003/09/12/opinion/12FR13.html?ex=1064395438\&ei=1\&en=27e80bf3221f45 c7.

${ }^{193}$ CNN, "Pain of 'Trail of Tears' shared by Blacks as well as Native Americans," CNN News Source, February 27, 2012, pp. 1-3 viewed June 28, 2013, www.Local10.com .
} 
speaks about her double identity and wrote, "I treasure my African American roots, and I also feel fully a part of the Cherokee community. Some of my fondest memories are of participating in wonderful Cherokee traditions, and the $\mathrm{CN}$ accepts me regardless of my racial appearance." ${ }^{194}$ Even though Williams wrote that she is accepted by the Cherokee Nation regardless of her racial appearance, she still explained that she possess Cherokee ancestry in addition to Freedmen ancestry, thus she has been accepted for tribal citizenship. What if Williams did not possess Cherokee ancestry? Would she still be accepted by the Cherokee Nation regardless of her racial appearance?

\section{Comments in Relation to Tribal Citizenship Benefits}

An article from the Arkansas Democrat-Gazette states how the Cherokee Nation sent letters "to about 2,800 descendants of slaves once owned by its' members, revoking their tribal citizenship and cutting off their medical care, food stipends, low income homeowners' assistance, and other services." 195

It seems that the descendants of Freedmen were voted out of the Cherokee Nation on March of 2007 for monetary reasons. In addition to medical, housing, education, and voting rights, "each member has a stake in growing casino revenue." 196 A The New York Times article titled "When Racial Discrimination Is Not Just Black and White" discusses how the Freedmen and their descendants are stripped of their tribal benefits.

White families have begun to acknowledge mix-race connections after centuries of denial. But attitudes of some Native Americans have not evolved in the same way. Both Seminoles and the Cherokee tribes have employed discriminatory

\footnotetext{
194 Williams, H., "Let Cherokees decide who's Cherokee," Cherokee Phoenix, August 2007, p. A-4.

195 Juozapavicius, J., “Cherokees revoke benefits for 2,008: Slaves' offspring cut from tribal rolls," Arkansas Democrat-Gazette, September 10, 2011, p. 5A.

196 Hatton, L., “'Black' Cherokees fight for heritage," USA Today, October 12, 2007.
} 
policies to prevent black members from receiving tribal benefits - and strip them of the right to vote in tribal elections. ${ }^{197}$

In another article from the Arkansas-Democrat Gazette, Freedman descendant Elma Howard is quoted on college scholarship benefits and wrote, "It's very important for my son to get benefits from the tribe, and he's got a daughter," and "She'll need a scholarship someday. I'm hoping she goes [to college]."198 There is no guarantee that Howard's granddaughter will earn a scholarship. As stated in the previous chapter, Cherokee scholarships are just like many scholarships and they are competitive.

Nevertheless, Howard is like most concerned family members and ultimately wants what is best for members of her family.

Freedman descendant and journalist Kenneth Cooper wanted to join the Native American Journalists Association, NAJA. Cooper wrote, "I was going to join NAJA several years ago, but to join you must be eligible for tribal membership, and I'm not."199 In contrast,

Kim Baca, executive director of NAJA, indicated it would not be a problem for Cooper and other Cherokee Freedmen to join NAJA. Its charter says, "Native American media professionals may be members of NAJA, hold office and vote. Individual members should be able to provide proof of tribal affiliation, if requested by the Board of Directors. ${ }^{200}$

\footnotetext{
197 Staples, B., "When Racial Discrimination Is Not Just Black and White," The New York Times, September 12, 2003, pp. 2-3, viewed on June 15, 2013, http://www.nytimes.com/2003/09/12/opinion/12FR13.html?ex=1064395438\&ei=1\&en=27e80bf3221f45 c7.

198 Smith, R., "Cherokee Lawsuit's focus on Citizenship," Arkansas-Democrat Gazette, February 2009, pp. 1-4 viewed on June 13, 2013 http://www.nwnews.com/News/252575/, p. 1.

199 Prince, R., “Cherokee Nation Ousts Blacks," Washington Afro American, March 10,2007, p. 1, viewed on April 13, 2014, http://news.newamericamedia.org/news/view article.html?article id=52479470a382404773a316f3c798 $334 f$. 200 Ibid.
} 
Additionally, "Baca noted that the language does not say members must be "enrolled" in a tribe, and said that in the two years she had been with the organization, it had not asked anyone for proof of tribal affiliation." ${ }^{201}$ However, it should be understood that anyone may still join NAJA, but they just can’t be a tribal NAJA member.

\section{Identity Crisis of the Descendants of Freedmen}

Sara Blakeslee and Marika Martin studied six women, who were members of the descendants of Freedmen organization. In Blakeslee and Martin's study, the main conclusion from their inductive analysis was that each of these descendants spoke on the topic of identity crisis. The women are torn between two cultural communities. Freedmen descendants are denied as Indian if they do not possess CDIB's. Simultaneously, the Freedmen descendants are not accepted as African-American either.

Being denied membership from both cultures is also discussed through religion.

One woman was noted in this study talking about religion and said,

That is what it is. It is faith. What we believe is parallel to Christianity to the point where a lot of members attend church too because they feel like it is no [sic] conflicting. Although some don't go out to the ceremonial grounds anymore. It got to the point where the leaders and the medical men for a little while were telling people if you leave and go to the church don't come back. ${ }^{202}$

Why were Freedmen descendants required to only choose one religious practice? This is frustrating for Freedmen descendants who want to participate in religious practices from both cultural backgrounds due to their double identity.

\footnotetext{
201 Ibid.

202 Blakslee, S., and Martin, M., "Influences on Identity: A Grounded Approach to Descendants of Freedmen," Journal of Feminist Family Therapy, 2009 , 21(4) pp. 271-283.
} 


\section{Traditionalism in the Cherokee Nation}

One citizen, who wrote his opinion in Talking Circles regarding the citizenship of the Cherokee Freedmen and how the vote to exclude them became a material matter. He explained,

This should have been considered and voted with a spiritual frame of mind. When we voted 'Yes', we became as those who made us walk the Trail of Tears. The descendants of the Freedmen, who have a Cherokee ancestor, was given no choice in being who they are. It is the Cherokee way of life to do right by others, to respect life no matter what they do to you. ${ }^{203}$

Another non-status Cherokee Indian wrote their opinion on Native identity and how it should be constructed in Talking Circles. This citizen wrote,

Native Identity should not be defined by European legalized ways of thinking. I can not find my grandmother on the (Dawes Commission) rolls. Does this make me any less Indian? I think not. Traditional ways of knowing and being are paramount to identity and should be respected. ${ }^{204}$

\section{Conclusion}

These findings combined the dialogue from actual citizens of the Cherokee Nation, dialogue that has been recorded from the Freedmen descendants and the descendants' allies. This dialogue is important because it is given from those who want change for Freedmen descendants' citizenship status as well as those who do not, for whatever reason that may be. However, the descendants of Freedmen still feel their identity connects them to the Cherokee Nation regardless of those who oppose their connectedness. This connectedness is discussed further in the next chapter.

\footnotetext{
${ }^{203}$ Glass, J. "Reconsider the 'Yes' vote," Cherokee Phoenix, May 2007, p. A-4.

204 Greer, D. "Native Identity," Cherokee Phoenix, July 2007, p. A-4.
} 


\section{CHAPTER VII}

\section{DISCUSSION \& CONCLUSION}

The findings of this research were categorized into these seven main themes:

Allies of descendants of Freedmen, Tribal Sovereignty, Remarks Constructed by Racial Bias, Self-Identification of the descendants of Freedmen, Comments in Relation to Tribal Citizenship Benefits, Identity Crisis of the Descendants of Freedmen, and finally Traditionalism of the Cherokee Nation. However, the main point of discussion that can be articulated out of the findings of this research is that the descendants of Freedmen's cultural identity as Cherokee Natives hinges upon their citizenship status. The findings prove that Freedmen descendants' connection to Cherokee identity is both a physical and a spiritual one.

There are some Freedmen descendants who want to have more tangible evidence in establishing their physical connectedness as Cherokee citizens such as possessing a citizenship card or a blue card as well as having it recognized for their authenticity as Cherokee citizens. As previously stated, Cherokee citizenship status is a benefit in itself. Those able to show proof can claim this cultural identity. Another piece of tangible evidence that the Freedmen descendants see and understand that they are in fact Cherokee citizens is the Treaty of $1866 .{ }^{205}$ Many physically need to have the same

\footnotetext{
205 Monet, J., "Freedmen Present Case: D.C. Circuit hears oral arguments in Cherokee Freedmen treaty dispute; Cherokee Nation repeats call to dismiss the case," Indian Country Today, 2(42) November 7, 2012, pp. 12-13.
} 
political rights as Cherokees. The descendants of Freedmen want to be a part of tribal elections. ${ }^{206}$ Additionally, they want their voices to be heard in these tribal elections. The physical connection comes through social construction and relationships established with Cherokee Natives. ${ }^{207}$ Part of this social construction is speaking the Cherokee language. This communication is what connected many of the Cherokee Freedmen and their descendants to this Cherokee identity as well as practicing traditions such as speaking the Cherokee language, music, dance, religious practices, etc. ${ }^{208}$ For many Cherokee Freedmen and their descendants, living the Cherokee life is the only life they know. A prime example of this is the case of Joseph "Stick" Ross.

Joseph "Stick" Ross was born into slavery in the Cherokee Nation and he was owned by Principle Chief John Ross. So first and foremost, he carries the name of a Cherokee Native. Upon emancipation, he was elected as a tribal councilman. He helped other Freedmen fight for their citizenship status. Ross was also married and had children in the Cherokee Nation. Eventually, Ross died in the Cherokee Nation. What is important to look at in this particular case is that Ross could have left the Cherokee Nation upon emancipation, but instead he stayed. Obviously, the Cherokee life was important to him, for it was the only life he ever knew. Joseph "Stick" Ross is Cherokee culturally regardless of his race or biological background. This should be taken into consideration when it comes to the citizenship status of the Freedmen descendants, but many members

\footnotetext{
206 Velie, J., "Bureau of Indian Affairs Recognizes Cherokee Election Although Black Citizens Forbidden Right to Vote," Velie \& Velie Attorneys at Law Press Release, August 7, 2003, p. 2.

207 Staples, B., "When Racial Discrimination Is Not Just Black and White," The New York Times, September 12, 2003, pp. 2-3, viewed on June 15, 2013, http://www.nytimes.com/2003/09/12/opinion/12FR13.html?ex=1064395438\&ei=1\&en=27e80bf3221f45 c7.

${ }^{208}$ Williams, H. “Let Cherokees decide who's Cherokee," Cherokee Phoenix, August 2007, p. A-4.
} 
of the Cherokee Nation perceives this issue differently. Unfortunately, because the descendants of Freedmen's citizenship has been disenfranchised, they can no longer be a part of what they know culturally, which has led them to an identity crisis.

Blakeslee and Martin's study of six Freedwomen has exposed this identity crisis. ${ }^{209}$ How can the descendants of Freedmen not be accepted into the AfricanAmerican community as well as the Cherokee community? Why should they have to choose one identity over the other? J. D. Pennington is both a Freedmen descendant and Cherokee. Granted he does have tribal citizenship status, and he still acknowledges and is proud of both heritages. ${ }^{210}$ Heather Williams is also both a Freedmen descendant and Cherokee. She also has tribal citizenship status and treasures both heritages. ${ }^{211}$ The descendants, who do not have tribal citizenship status, know and believe that they are from both cultural backgrounds, which is what makes this a spiritual connection for them. To the descendants, their Cherokee identity is about having faith in knowing who you are and knowing your heritage. Originally Cherokees believed all members of the same clan shared the same blood. This included members who were adopted into clans even if they were white or African.

The Cherokee Freedmen and their descendants believe that they really are Cherokee. ${ }^{212}$ The fact that they cannot prove their Native ancestry on a roll that is not a credible source of information, does that make them any less Cherokee? How are they less Cherokee? The Freedmen descendants have ancestors who walked the Trail of

\footnotetext{
${ }^{209}$ Blakslee, S., and Martin, M., "Influences on Identity: A Grounded Approach to Descendants of Freedmen," Journal of Feminist Family Therapy, 2009, 21(4) pp. 271-283.

210 Good Voice, C., "Perspectives differ on Cherokee vote," Cherokee Phoenix, April 2007, p. A-2.

211 Williams, H., "Let Cherokees decide who's Cherokee," Cherokee Phoenix, August 2007, p. A-4.

212 Cooper, K., "Citizenship Deferred: Descendants of Cherokee Slaves Known as Freedmen, Are Still Fighting for Voting Rights and Basic Services," Diverse, 2011, pp. 12-13.
} 
Tears, ${ }^{213}$ fought with Cherokees in battles and most importantly built strong bonds with Cherokee Natives. This disenfranchisement from the Cherokee Nation is a discriminatory concept. Marilyn Vann, the President of the Descendants of Freedmen Organization, feels that this fight for tribal citizenship status is not only important for herself, but it is also important to stand up for her ancestors as well. Vann, along and other freedmen descendants fighting for tribal citizenship status, does not want to be stripped of their identity. ${ }^{214}$ The findings show that not only is the Cherokee Nation perceived as being racist in its' exclusion of the Freedmen descendants, but the Cherokee Nation has also been observed as greedy. ${ }^{215}$ Is this not the same mentality of white settlers and the Dawes Commission?

White settlers were ultimately a negative influence to Cherokees in regard to racial ideology. It is obvious that this is another case where racism was imposed upon people of color by white settlers. Cherokees knew about and understood the hierarchy of white settlers. Even though they felt that they were above the white man, they still knew that white settlers were at the top of this hierarchy. In an effort of survival and to not be seen as inferior to white settlers, Cherokees had to assimilate to the white ways of life, for white settlers could not be trusted. The ultimatum was either assimilate or have their people wiped out. This assimilation included racial issues such as enslavement, blood quantum, and the ways in which the Cherokees wrote their government documents, in particular, the constitution.

\footnotetext{
${ }^{213}$ CNN, "Pain of 'Trail of Tears' shared by Blacks as well as Native Americans," CNN News Source, February 27, 2012, pp.1-3 viewed June 28, 2013, www.Local10.com.

${ }^{214}$ Chavez, W., "Freedmen file injunction to halt constitutional change," Cherokee Phoenix, June 2007, p. A-2.

${ }^{215}$ Hatton, L., “'Black' Cherokees fight for heritage," USA Today, October 12, 2007.
} 
Members of the Cherokee Nation see this as an invalid claim, ${ }^{216}$ but as stated earlier, the Dawes Commission recorded several Freedmen incorrectly due to their racial bias. So it is possible African-Americans who are seen as ineligible when it comes to their citizenship status might actually be eligible but are not able to prove it. The blood record was not necessarily a way to determine who was a citizen of the Cherokee Nation but more of a way for the federal government to figure out who they could take advantage of first. Therefore, the blood record is actually an invalid claim. While it is unfortunate that the Treaty of 1866 was forced upon the Cherokee Nation by the federal government, the treaty was still signed, which makes this documentation legally binding.

This research has shown that before white settlers entered the Cherokee Nation, Cherokees had a variety of ways of choosing citizens as a part of their nation. If the Cherokees chose to adopt someone or marry someone, then they did. If Cherokees wanted to decide citizenship based upon blood through matrilineal descent, then that was their choice. Additionally, Cherokees chose to adopt African-descended individuals as citizens. Even though granting African-descended individuals citizenship at this time was mostly business, it does not mean that meaningful relationships did not come out of that social contact. Cherokees even took their own census of citizens within their nation. However, all self-determination of citizenship changed due to the cultural hegemony of white settlers' racism toward African individuals imposed upon Cherokees. Additionally, the cultural hegemony of white settlers' use of blood quantum was imposed upon Cherokees. Blood quantum was not traditional to Cherokee identity. Currently, Cherokees might be seen as racist due to the current issues regarding citizenship status

${ }^{216}$ Washington, O., "Identity is the higher priority," Cherokee Phoenix. September 2007, p. A-4. 
for the descendants of Freedmen, but cultural hegemony explains how this racism came to be.

Today, people get angry about having to show proof, but this is an issue of trust. The Cherokee Nations' mission statement is "The Cherokee Nation is committed to protecting our inherent sovereignty, preserving and promoting Cherokee culture, language and values and improving the quality of life for the next seven generations of Cherokee citizens." 217 The federal government should not be involved because they cannot be trusted. Can you blame the Cherokee Nation for feeling this way? The federal government has dictated so much for Cherokees. As explained in many of the comments from the Talking Circles section of the Cherokee Phoenix, the Cherokee Nation needs to be allowed to decide for themselves who they want as tribal citizens. It is their sovereign right to do so. ${ }^{218}$ In the Cherokee Phoenix, Principal Chief Chad Smith explained how he is proud of the Cherokee Nation for voting to keep the federal government and the BIA out of their constitutional process. In the same article, he gives instances where the federal government should have respected Cherokee tribal sovereignty because negative results stem from the federal governments disrespect. Some instances where negative results came from the federal government disrespect towards tribal sovereignty land allotment and the Trail of Tears. ${ }^{219}$

The findings of this research show who the allies of the Freedmen descendants are as well as what they have done to support themselves in their fight for tribal citizenship

\footnotetext{
217 The Cherokee Nation's Mission Statement, viewed on April 20, 2014, http://www.cherokee.org/OurGovernment.aspx.

218 Jennings, J., "Cherokee Freedmen: One Year Later," Indian Country Today Media Network.com, January 31,2012, pp. 1-2, viewed on July $13^{\text {th }} 2013$, http://www.indiancountrytodaymedianetwork.com/ict sbs/Cherokee-freedm. ${ }^{219}$ Smith, C., "All should be supporting sovereignty," Cherokee Phoenix, August 2007, p. A-4.
} 
status. It is important to understand at times more harm was accomplished in articles and opinions in the Talking Circles section of the Cherokee Phoenix. Congresswoman Diane Watson was considered ignorant to the history of citizenship in the Cherokee Nation, for she did not research her own ancestry well. This was supposed to be her grounds for supporting the Cherokee Freedmen and their descendants, for she is African American and "Native" as well. Watson claims to be a descendant of Pocahontas, but according to Cherokees, she does not know what Nation Pocahontas was from. ${ }^{220}$ To be considered Native, one must be able to prove their authenticity.

In an interview Watson said defining tribal sovereignty and self-determination was irrelevant when it came to the issue of citizenship status for the Freedmen descendants. ${ }^{221}$ This again shows how Watson did not do her research, for tribal sovereignty has everything to do with the descendants of Freedmen's citizenship status. Tribal sovereignty is how the Cherokee Nation decides who citizens are. It is their way of protecting their people.

Finally, Congresswoman Watson wanted to pass the HR 2824 bill, which cut federal funding to the Cherokee Nation. ${ }^{222}$ This funding was needed by elders, children, and those who worked for the Cherokee Nation. Potentially taking this money away angered citizens in the Cherokee Nation. Ultimately, Watson was perceived as careless, and she did not gain respect from Cherokee citizens.

\footnotetext{
${ }^{220} \mathrm{Hix}, \mathrm{B}$. “A little scared of Watson's Ignorance," Cherokee Phoenix, October 2007, p. A-4.

${ }^{221}$ Ross, G., "Facts don't interest Watson," Cherokee Phoenix, November 2007, p. A-4.

222 Good Voice, C., "Watson seeks funding cut to Cherokee Nation," Cherokee Phoenix, September 2007, Front page.
} 
Jon Velie is the Freedmen descendants' lawyer, who has helped the Freedmen with federal issues concerning this fight for citizenship. What makes him a respectable advocate in the Freedmen descendants' fight for tribal citizenship is that he is knowledgeable on the current citizenship issues. Velie is known as an Indian Law expert. ${ }^{223}$ Prior to defending the Cherokee Freedmen and their descendants, he defended the Seminole Freedmen in their fight to equal citizenship after the Seminole Nation voted to disenfranchise them back in $2000 .^{224}$

Another outside ally of the Freedmen descendants, when it comes to equal voting rights, is John Stremlau. He is also a respectable supporter of the Freedmen and their descendants, for he is knowledgeable on the voting restrictions put on the Freedmen descendants. What is interesting about Stremlau as a supporter is that the descendants did not call upon him for his support. The Cherokee Nation called upon him to monitor the election for the next Principal Chief. ${ }^{225}$ Even though the descendants did not call upon Stremlau to monitor the election in 2011 , he can still be considered an ally, for he made sure that the election was a fair election for everyone involved.

Cherokee David Cornsilk went against the Cherokee Nation when he decided to become an ally to the Cherokee Freedmen and their descendants. Cherokees were not pleased with his decision, ${ }^{226}$ but he had an understanding of the current problems in relationship to the descendants of Freedmen's tribal citizenship status. As a genealogist who worked in the registration office of the Cherokee Nation, Cornsilk saw firsthand how

${ }^{223}$ The Associated Press, "Tribe Slave Descendants Face Uncertainty," Velie Law Firm Newsroom, March 4, 2006, viewed on July 31, 2014, http://www.velielaw.com/showArticle.asp?articleid=29.

224 Ibid.

225 Stremlau, J., "Black Cherokees exercise hard-won right to vote," CNN News Source, Updated October 19, 2011, pp. 1-2 viewed on June 11, 2013, www.cnn.com .

${ }^{226}$ Samuels, A., "What Does Indian Blood Look Like," Ebony, 2008, p. 97. 
the Cherokee Nation denied the Freedmen and their descendants' citizenship and felt that they were being cheated once he delved into their ancestral history. ${ }^{227}$ Cornsilk attended meetings of the descendants of Freedmen organization where he explained to them that they were Cherokee. Cornsilk does not feel that the fight for citizenship should be aided by the federal government, for he does not trust the federal government himself. Cherokees might be upset that he has turned against the Cherokee Nation, but Cornsilk is taking a stand for what he believes as a Cherokee citizen. He feels that the descendants of Freedmen are Cherokee, and he is expressing his views as a Cherokee citizen.

Cornsilk is not the only Cherokee who is expressing his opinion. There are other Cherokee citizens who think the descendants have been cheated. The findings on Cherokee traditionalists show that there are Cherokees who believe that the election to disenfranchise the Freedmen descendants was based upon material reasons. ${ }^{228}$ Another citizen explains that Cherokee identity should not be based upon a blood policy, for that is a European concept. ${ }^{229}$ Unfortunately, due to cultural hegemony, this policy is still in effect today, and this is what the Cherokee Nation grounds its' citizens authenticity on as Cherokee people.

There are several benefits to having tribal citizenship status as explained in Chapter VI of this thesis. One benefit is health care. ${ }^{230}$ Another benefit that is important to the descendants of Freedmen is the loss of scholarships for higher education. ${ }^{231}$ It

\footnotetext{
227 Barbery, M., "From One Fire," This Land, 4 (10), May 15, 2013.

228 Glass, J., "Reconsider the 'Yes' vote," Cherokee Phoenix, May 2007, p .A-4.

${ }^{229}$ Greer, D., "Native Identity," Cherokee Phoenix, January 2007, p. A-4.

230 Juozapavicius, J., "Cherokees revoke benefits for 2,008: Slaves' offspring cut from tribal rolls," Arkansas Democrat-Gazette, September 10, 2011, p. 5A.

${ }^{231}$ Smith, R., "Cherokee Lawsuit's focus on Citizenship," Arkansas-Democrat Gazette, February 2009, pp. 1-4 viewed on June 13, 2013, http://www.nwnews.com/News/252575/, p. 1.
} 
seems that both the Seminole and Cherokee Nation have employed discriminatory practices to exclude descendants of Freedmen from tribal citizenship. ${ }^{232}$ The main requirement for people wanting to obtain tribal benefits is citizenship status. Without citizenship status, tribal benefits cannot be obtained. This leads to the next half of this chapter, which is the conclusion of this research.

The first conclusion in this research is that the problem of the color-line is not only a problem of the $20^{\text {th }}$ century, but it is still a problem of the $21^{\text {st }}$ century. The problem of the color-line is both an internal problem and an external problem for the Cherokee Nation. It is an internal problem, for it effects all of the citizens within the Cherokee Nation. The Cherokee Nation wants to decide for themselves, who is Cherokee and who is not. However, this put a rift between citizens who are not able to prove their Cherokee ancestry and ones that can due to the federal governments documentation, which started in 1906 and ended in 1975. The problem of the color-line becomes an external problem when the federal government oversteps their boundaries to dictate citizenship status for the Cherokee Nation.

Another important finding is that not only are the Descendants of Freedmen suffering from an identity crisis, but it also seems that Cherokees themselves are suffering from an identity crisis. Cherokees have gone against their own traditions and norms for how they articulate their own cultural identity. Blood might be a part of Cherokee identity, but blood quantum is not a Cherokee concept. Blood quantum is a

\footnotetext{
${ }^{232}$ Staples, B., "When Racial Discrimination Is Not Just Black and White," The New York Times, September 12, 2003, pp. 2-3, viewed on June 15, 2013, http://www.nytimes.com/2003/09/12/opinion/12FR13.html?ex=1064395438\&ei=1\&en=27e80bf3221f45 c7.
} 
European concept that was forced upon them as part of establishing their Cherokee identity. The problem with blood quantum is it does not make any sense. How can someone only be quanta of one fourth something or three fourths of something? It should be understood that if a person chooses to self-identify as something, then they will identify as whatever that something is. ${ }^{233}$ There is no way to prove someone's cultural identity based upon blood. Blood is something that is universal. Granted there are different blood types such as A, B, AB, O, etc., but these types do not define someone's race or cultural identity.

The Dawes Commission was part of the federal government and consisted of white settlers, who had a racial bias and practiced racist science, which lasted for almost 70 years. If anyone is to blame for the inaccuracies in the Dawes Rolls, it is the federal government. For far too long, the federal government has taken from the Cherokee Nation and has forcefully dictated how they should run their own nation. Should Cherokees not be allowed to decide for themselves who they are as citizens?

President Barack Obama thinks that the Cherokee Nation should resolve the issues of citizenship on its own, for this is an inter-tribal issue of the color-line. If the federal government becomes involved again, how will it be any different from the past? The federal government made this a problem of the color-line in the first place, which is why they should not be involved today. How does a nation of people change their ideologies of race when these same ideologies have been practiced for centuries? Because Cherokees have assimilated to racial ideologies of the white man, it appears this is what they have become accustomed to.

${ }^{233}$ Good Voice, C., "Perspectives differ on Cherokee vote," Cherokee Phoenix, April 2007, p. A-2. 
Who knows when these current issues will be resolved for the descendants of Freedmen regarding their tribal citizenship status? Are the Freedmen descendants ever going to be a part of the core society? Or, will they always be the periphery society as outsiders looking in? An important part of the epistemology for this research involves making sure the results of this study are respectful and reciprocated back to the community, so the next step for this research is to see if the Cherokee Nation would like the findings of this research presented to them.

There was one concern in looking through the findings of this research, which perhaps is a future avenue of research in this field. There were not many young opinions in the newspapers about the Freedmen descendants. Even looking at the photos of people campaigning, it does not appear that there are any younger people campaigning. How many young voters are in the Cherokee Nation? Do they vote in these elections? Do they even know or care about the current issues regarding the Freedman Descendants? How do younger citizens view race relations in the Cherokee Nation? It is important to answer all of these questions because it might take a younger generation of voters to swing the election in favor of the descendants of Freedmen. If this is the case, Freedmen descendants might need to approach young voters in a different way.

Essentially, the first presidential campaign for President Barak Obama was targeted at a younger generation through social media and political campaigning on college campuses, which is arguably what helped him get elected as the first AfricanAmerican President of the United States. Which brings to question what if the Freedmen descendants targeted young voters on social media and campaigned at tribal colleges and universities? It would be interesting for future research to know what younger citizens of 
the Cherokee Nation think on these current matters. Does the younger generation of the Cherokee Nation think that "It's time for a change?" This dialogue is important because ultimately the younger generation will carry on the customs and traditions of the Cherokee Nation. 


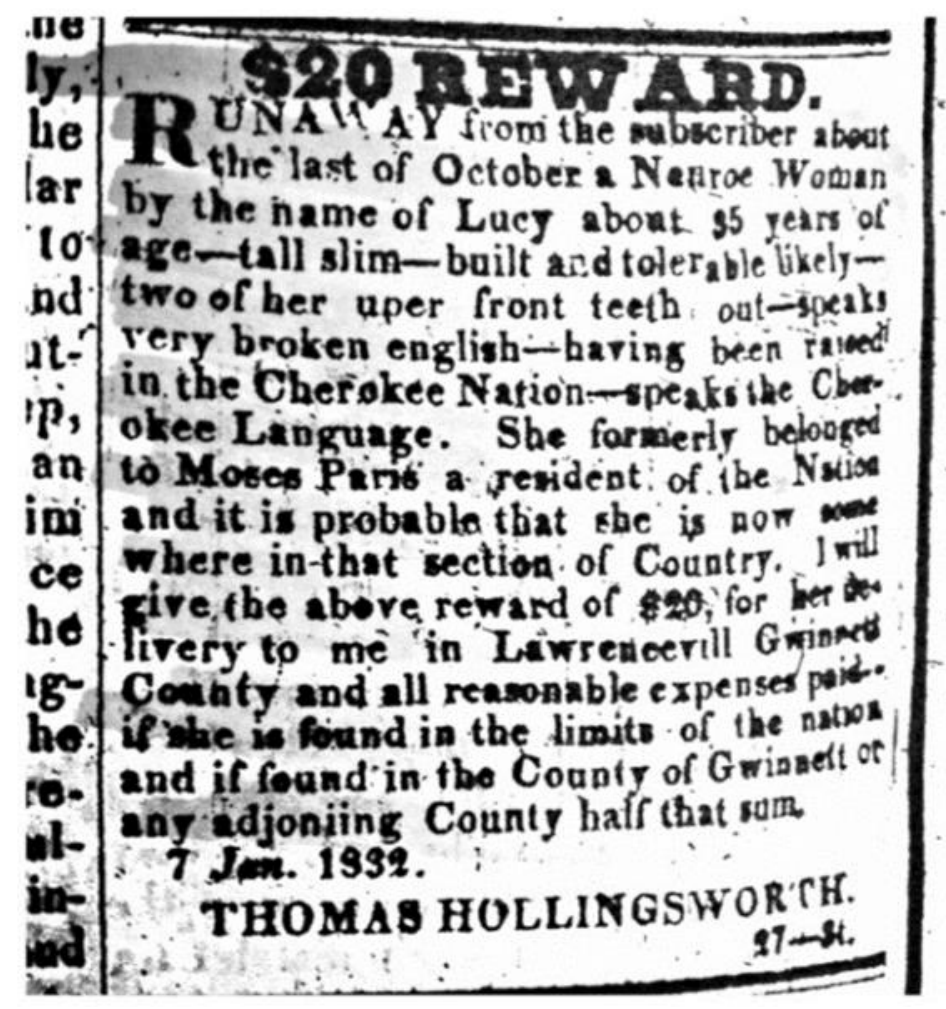

(Illustration 4.1) Runaway notice for Lucy ${ }^{234}$

\footnotetext{
${ }^{234}$ Hollingsworth, T., \$20 Reward in Cherokee Phoenix \& Indians Advocate, 1832, 4(27). Personal photograph taken of the notice.
} 


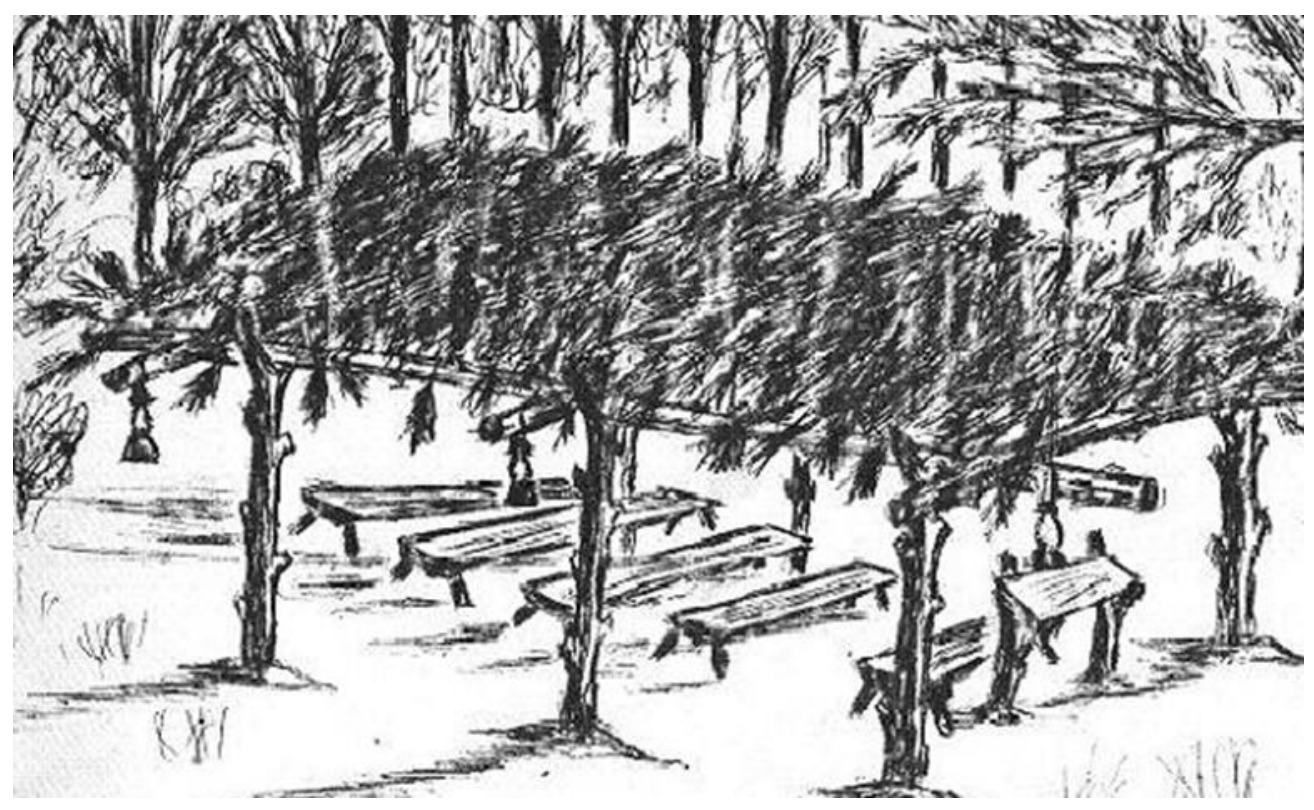

(Illustration 4.2) Brush Arbor 235

235 Illustration of a Brush Arbor found on http://confederatelegion.com/Brush_Arbor_Days.html, viewed on March 26, 2014. 


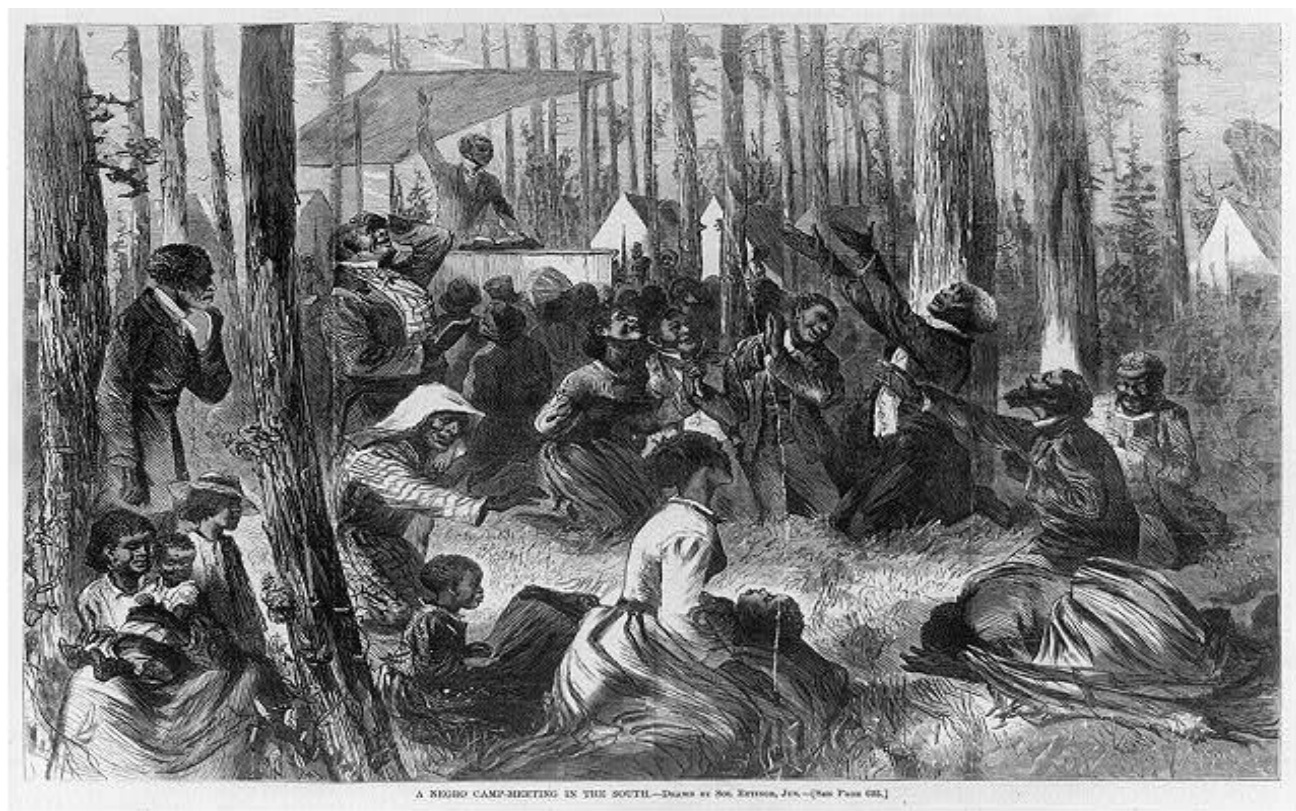

(Illustration 4.3) Camp Meeting ${ }^{236}$

${ }^{236}$ Illustration of $A$ Negro Camp Meeting in the South found on http://nonebutgod1.blogspot.com/2012/09/a-brush-arbor-service.html\#.UzwLkJTD_IU, viewed on March, 26, 2014. 


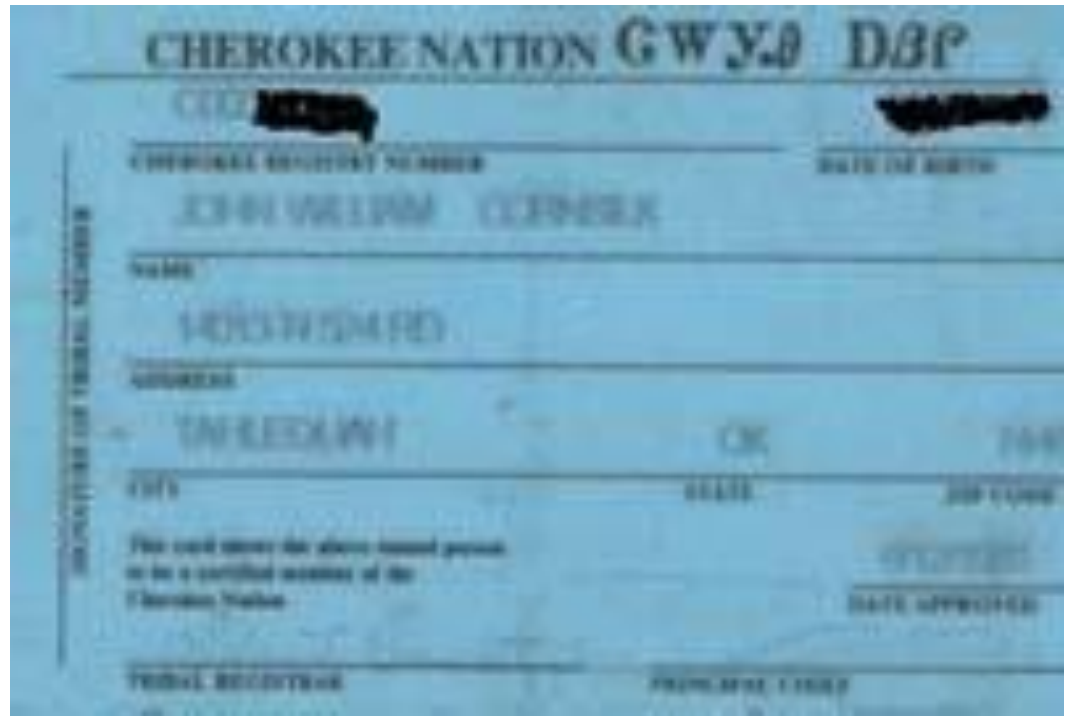

\section{(Illustration 5.1) Original Blue Card for Tribal Citizenship ${ }^{237}$}

This card displays the citizens' enrollment number on the top left corner of the card. A date of birth is on the top right corner, which is followed by a name, address, the date of approval, which is finally followed by the Tribal Registrar and the Principal Chiefs' signatures.

\footnotetext{
237 Illuatration of John Cornsilk's blue card for tribal citizenship status in the Cherokee Nation, found on http://www.network54.com/Forum/237458/message/1286717726/Yes+Bill+1+suspect+David+voted+for+ it,+as+l+would+probably+have,+if+we+gotta+live+with+the, viewed on March 26, 2014.
} 

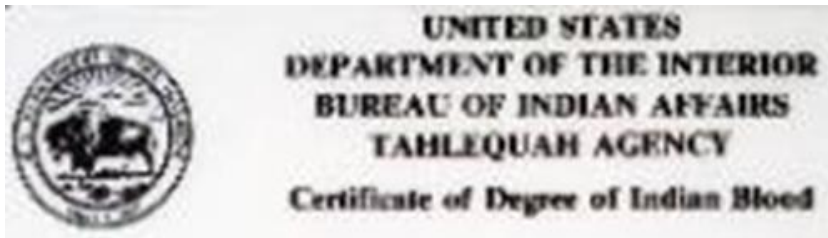

This is so certify that

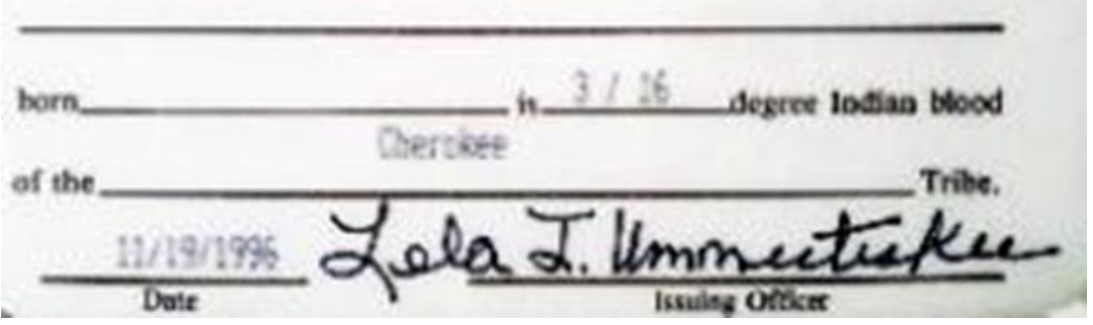

\section{(Illustration 5.2) CDIB for Determining Citizenship by Blood ${ }^{238}$}

This card displays a citizen's name, date of birth, degree of Indian blood, what Nation their Indian blood is from, the date their CDIB was issued, and finally the Issuing Officer's signature.

\footnotetext{
238 Illustration of Certificate Degree of Indian Blood, found on http://publicradiotulsa.org/post/babyveronica-case-stirs-questions-about-blood-quantum-hear-our-special-report, viewed on March 26, 2014.
} 


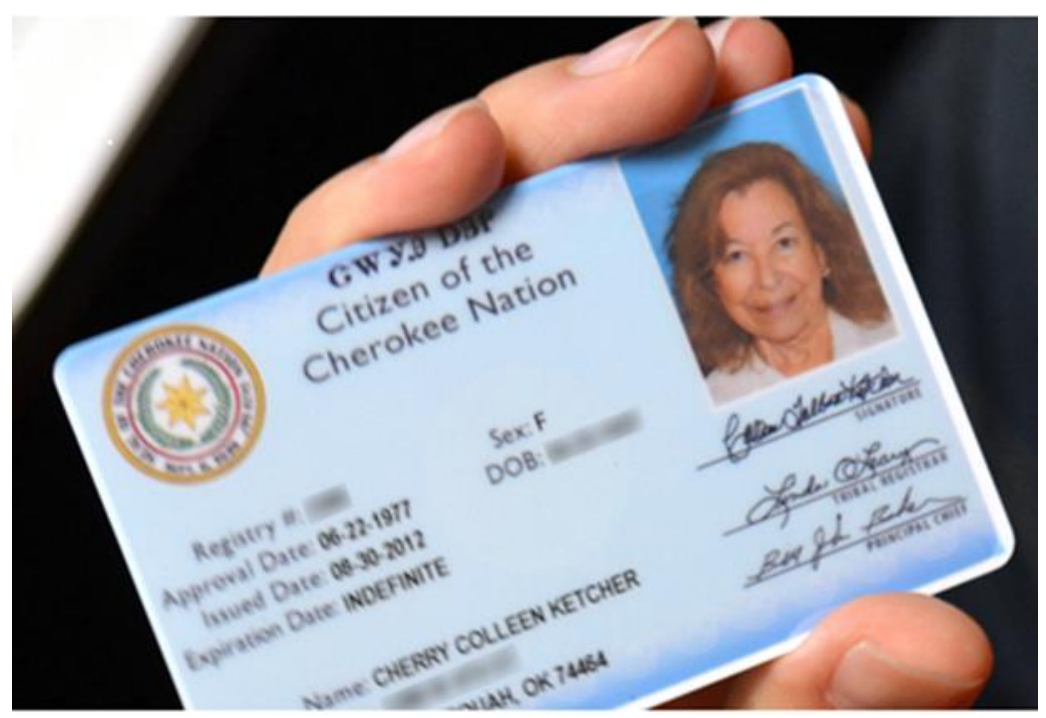

(Illustration 5.3) Cherokee Citizenship "blue card" as a Photo I.D. ${ }^{239}$

This is an example of a "blue card" looks like". It displays all of the same information as the original blue card, but it additionally displays an expiration date, issue date, and photo. The new photo I.D.'s display the citizens' CDIB on the back of the card.

\footnotetext{
239 Dafferon, Brian, "Cherokee Nation Issue New Photo ID; Card Does Not Meet Oklahoma Voter ID Criteria," Indian Country Today Media Network.com.

http://indiancountrytodaymedianetwork.com/2012/10/31/cherokee-nation-issue-new-photo-id-carddoes-not-meet-oklahoma-voter-id-criteria-143140, viewed on March 26, 2014.
} 


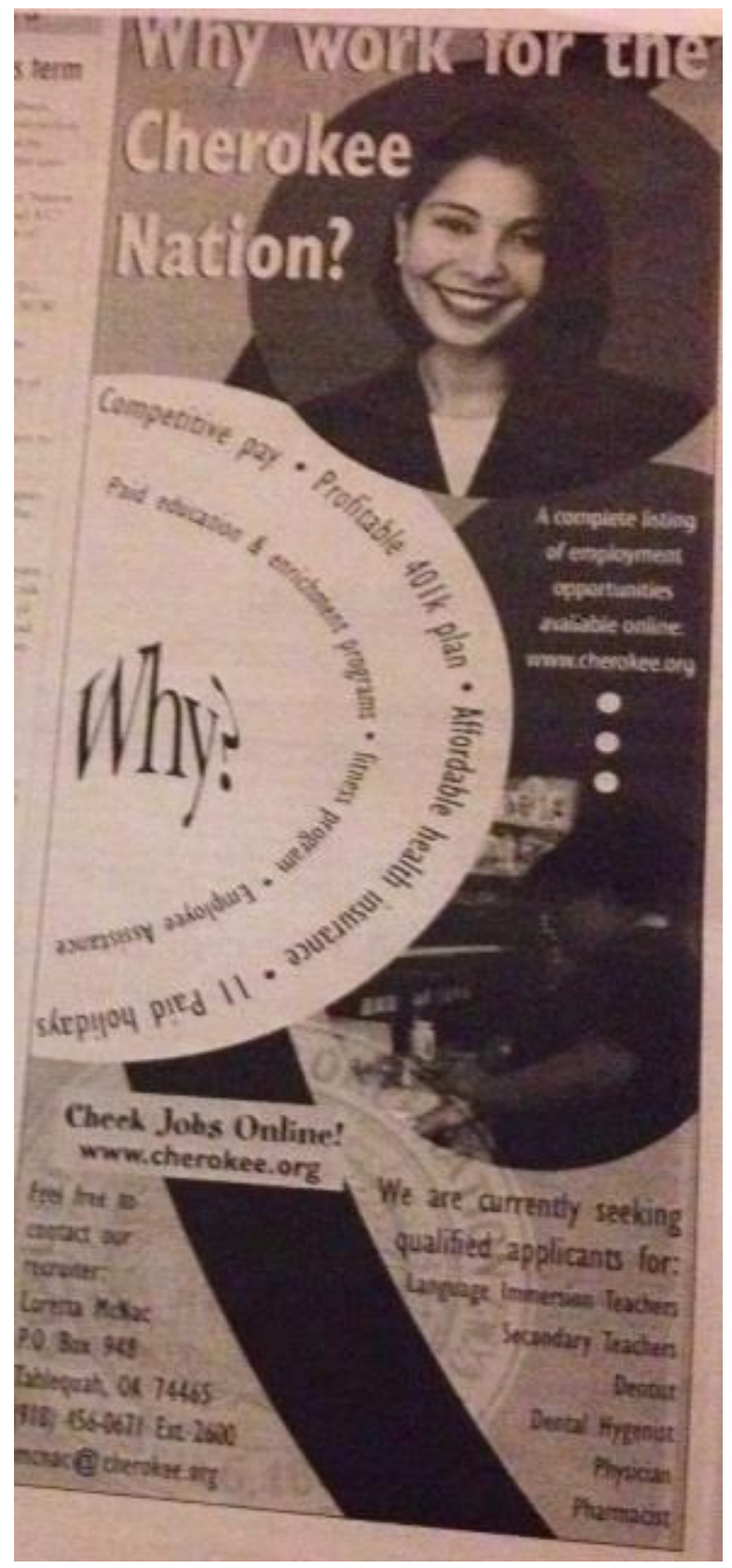

(Illustration 5.4) Benefits of Tribal Employment Advertisement. ${ }^{240}$

\footnotetext{
240 Personal photo taken of an ad presenting the benefits of working for the Cherokee Nation. Cherokee Phoenix, September 2003, p. 4.
} 


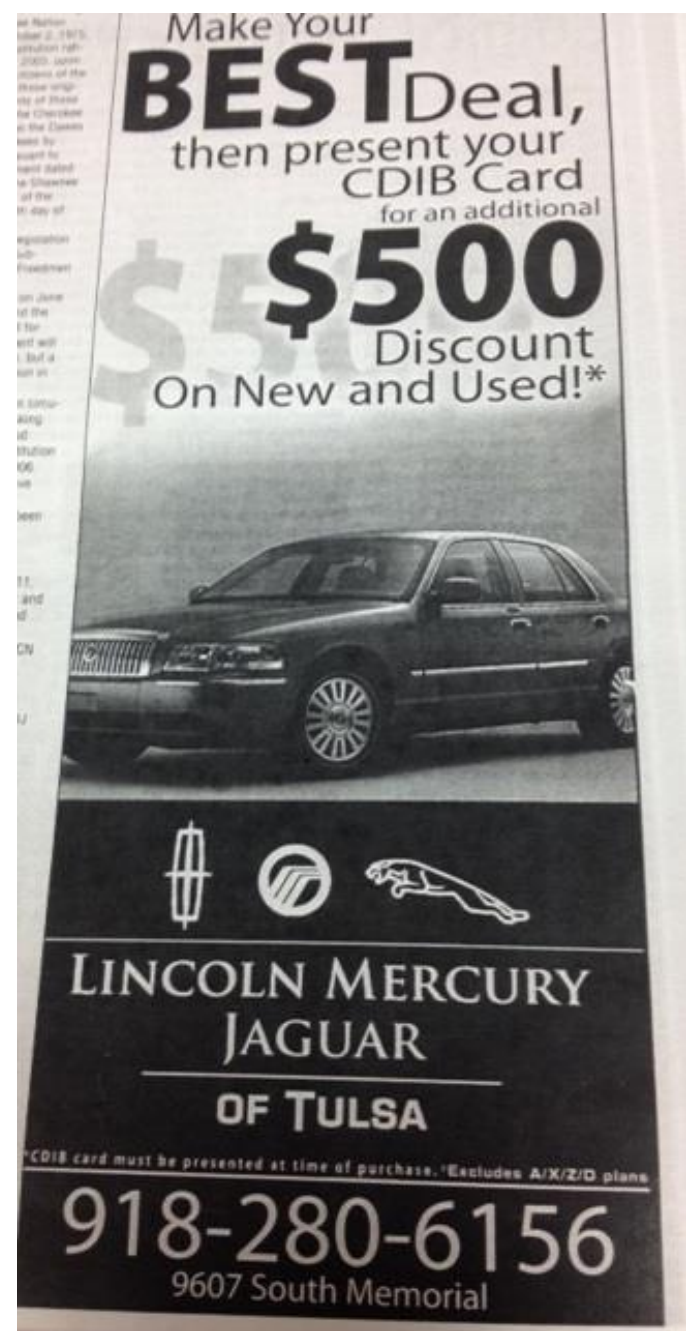

(Illustration 5.5) Dealership ad in the Cherokee Phoenix presenting a CDIB discount of $\$ 500$ off on a new or used car. ${ }^{241}$

\footnotetext{
${ }^{241}$ Personal photo taken of an ad presenting a $\$ 500$ discount on a new or used car to those in possession of a CDIB card., Cherokee Phoenix, August 2006, p. 5.
} 


\section{AN EXPLANATION OF TERMINOLOGY}

In this text there are terms that are used interchangeably such as, Native

American, Native, Natives, and Indians. These terms are used when explaining something about Native Americans as a whole. All of the terms mean the same thing in this text. The terms Cherokees and Native Cherokees are used interchangeably, but also mean the same thing. Sometimes descendants of Freedmen and Freedmen descendants are used interchangeably, but mean the same thing. 


\section{REFERENCES}

Adams, David Wallace. Education for Extinction: American Indians and the Boarding School Experience, 1875-1928. Lawrence, KS.: University Press of Kansas, 1995. 18.

African American Lives, DVD. Peter Kunhardt, New York, Thirteen WNET, PBS: 2006.

Agent, Dan. "The Cherokee Nation Under Siege." In Indivisible: African American Lives in the Americas. Washington D.C., Washington: Smithsonian Books, 2009. 123.

Anderson, James D. The education of Blacks in the South, 1860-1935. Chapel Hill: University of North Carolina Press, 1988. 31.

Baker, T. Lindsay, and Julie P. Baker. The WPA Oklahoma Slave Narratives. Norman, OK: University of Oklahoma Press, 1996. 356-357.

Barbery, Marcos. "From One Fire." This Land 4, no. 10 (2013): 1-21. http://thislandpress.com/05/16/2013/from-one-fire/?read=complete (viewed on June 15, 2013).

Berkhofer, Robert F. The White Man's Indian: Images of the American Indian, from Columbus to the Present. New York: Vintage Books, 1979. 55-61.

"BIA Website." Indian Affairs. http://bia.gov/WhoWeAre/ (accessed May 23, 2014).

Bird, S. Elizabeth, and Debra Merskin. "What Does One Look Like?" In Dressing in Feathers: the Construction of the Indian in American Popular Culture. Boulder, CO: Westview Press, 1996. 281-284. 
Blakeslee, Sara E., and Marika L. Martin. "Influences on Identity: A Grounded Theory Approach to Descendants of Freedmen." Journal of Feminist Family Therapy 21, no. 4 (2009): 271-283.

Bramen, Carrie. The Uses of Variety: Modern Americanism and the Quest for National Distinctiveness. Cambridge, MA: Harvard University Press, 2000. 227.

Brooks, James. Confounding the color line: the Indian-Black experience in North America. Lincoln: University of Nebraska Press, 2002. 12, 137-139.

Browder, Anthony T. From the Browder file: 22 essays on the African American experience. Washington, D.C.: Institute of Karmic Guidance, 1989. 1.

Brown, Mary Ellen. Burns and Tradition. Urbana: University of Illinois Press, 1984. XII. Bryman, Alan. Social Research Methods. 4th ed. Oxford: Oxford University Press, 2012. 402,714 .

Castro, Justin. "Music Heard Deeply: Song and Ethnic Interaction in the Cherokee Ozarks” (Master's thesis, University of Central Oklahoma, 2008), 74, 77.

Chavez, Will. "BIA to CN: special election not approved." Cherokee Phoenix (Tahlequah), May, 2007. A-2.

Chavez, Will. "Cherokee Nation/Freedmen Timeline." Cherokee Phoenix (Tahlequah), August 2006. A-3.

Chavez, Will. "Freedmen file injunction to halt constitutional change." Cherokee Phoenix (Tahlequah), July 1, 2007. A-2.

Cherokee Advocate (Tahlequah), July 30, 1879.

Cherokee Nation Judicial Appeals Tribunal, Allen vs. Cherokee Nation, JAT-04$09.5,12,15$. 
Cherokee Nation. "Our Government." Our Government. Mission http://www.cherokee.org/OurGovernment.aspx (viewed on April 19, 2014).

Clayton, Thomas., Rethinking Hegemony, Melbourne: James Nicholas Publishers, 2006, p.2.

CNN, "Pain of 'Trail of Tears' shared by Blacks as well as Native Americans," February 27, 2012. local10.com (viewed on June 28, 2013).

Collins, Lee. "Happy about special election." Cherokee Phoenix (Tahlequah), May, 2007, sec. Talking Circles. A-4.

Conley, Robert J. Cherokee Thoughts, Honest and Uncensored. Norman: University of Oklahoma Press, 2008. 151-153.

Cooper, Kenneth. "Citizenship Deferred: Descendants of Cherokee Slaves Known as Freedmen, Are Still Fighting for Rights and Basic Services." Diverse, December 14, 2011. http://diverseeducation.com/article/16698/ (accessed July 15th, 2013). Constitutional Convention Commission, Cherokee Nation. "The 1999 Constitution of the Cherokee Nation: A review and comparison between the 1976 and 1999

Constitutions of the Cherokee Nation in preparation for Ratification Vote on July 26th, 2003." Reading, Constitution Convention from Cherokee Nation, Tahlequah February 26, 1999. 3.

Cornell, Stephen E., and Douglas Hartmann. "Mapping the Terrain." In Ethnicity and race: making identities in a changing world. 2nd ed. Thousand Oaks, Calif.: Pine Forge Press, an Imprint of Sage Publication, 2007. 15-40.

Creswell, John W. Research Design: Qualitative, Quantitative, and Mixed Method Approaches. 3rd ed. Thousand Oaks, Calif.: Sage Publications, 2009. 98. 
Cumfer, Cynthia. Separate peoples, one land: the minds of Cherokees, Blacks, and Whites on the Tennessee frontier. Chapel Hill: University of North Carolina Press, 2007. 114.

Dafferon, Brian. "Indian Country Today Media Network." Cherokee Nation Issue New Photo ID; Card Does Not Meet Oklahoma Voter ID Criteria. http://indiancountrytodaymedianetwork.com/2012/10/31/cherokee-nation-issuenew-photo-id-card- does-not-meet-oklahoma-voter-id-criteria-143140 (viewed on March 26, 2014).

Davis, John. "The Life and Work of Sequoyah." Chronicles of Oklahoma (Tahlequah), June, 1930. http://digital.library.okstate.edu/chronicles/v008/v008p149.html (viewed on May 19, 2014).

Du Bois, W. E. B., The College-Bred Negro. Atlanta, Ga.: Atlanta University Press, 1900. 87.

Du Bois, W.E.B., The Souls of Black Folk. New York, NY: Dover Publications, 1994. 2-3, 9 .

Duvall, Deborah. Tahlequah and the Cherokee Nation. Chicago, IL: Arcadia Publishing, 2000. 14.

Fogelson, Raymond. 'On the 'Petticoat Government' of the Eighteenth-Century Cherokee," Personality and the Cultural Construction of Society: Papers in Honor of Melford E. Spiro. (Tuscaloosa, AL: University of Alabama Press), 1990. $173-174$.

Frederick Douglass. VHS. Directed by Craig Haffner. New York: A \& E Home Video, 1994. 
"Frequently Asked Questions." Frequently Asked Questions.

http://www.cherokee.org/Services/TribalCitizenship/FrequentlyAskedQuestions.a spx (viewed on March 26, 2014).

Gates, Henry Louis. "Writing 'Race' and the Difference it makes." "Race," Writing, and Difference. Chicago: University of Chicago Press, 1986. 1-20.

Germino, Dante, Antonio Gramsci Architect of a New Politics, Baton Rouge: Louisiana State University Press., 1-2, 8, 50.

Giddings, Paula. When and Where I Enter: The Impact of Black Women on Race and Sex in America. New York: W. Morrow, 1984. 29.

Glass, John. "Reconsider the 'Yes' vote." Cherokee Phoenix (Tahlequah), May, 2007, sec. Talking Circles. A-4.

Glenn, E. N. "Constructing Citizenship: Exclusion, Subordination, and Resistance." American Sociological Review 76, no. 1 (2011): 1-24.

Good Voice, Christina. "Watson seeks funding cut to Cherokee Nation." Cherokee Phoenix (Tahlequah), September, 2007. Front Page.

Good Voice, Christina. "Perspectives differ on Cherokee vote." Cherokee Phoenix (Tahlequah), April, 2007. A-2.

Goss, Linda, Marian E. Barnes, and Henry Gates Jr. "Introduction: Narration and Cultural Memory in the American Tradition.” Talk That Talk: An Anthology of African-American Storytelling. New York: Simon \& Schuster, 1989. 15.

Gramsci, Antonio, Quintin Hoare, and Geoffrey Smith. Selections From the Prison Notebooks of Antonio Gramsci. New York: International Publishers, 1971. 12. 
Greer, Dawn. "Native identity." Cherokee Phoenix (Tahlequah), July, 2007, sec. Talking Circles. A-4.

Gross, Ariela Julie. What Blood Won't Tell: A History of Race on Trial in America. Cambridge, Mass.: Harvard University Press, 2008. 112.

Halliburton, R. Red over Black: Black Slavery Among the Cherokee Indians. Westport, Conn.: Greenwood Press, 1977. 193-194.

Hatton, Lois. "'Black’ Cherokees fight for heritage." USA Today (Tysons Corner), October 12, 2007.

Hix, Bill. "A little scared of Watson's Ignorance." Cherokee Phoenix (Tahlequah), October, 2007, sec. Talking Circles. A-4.

Hollingsworth, Thomas. "\$20 Reward" Cherokee Phoenix \& Indians Advocate 4, no. 27 (1832). Personal photo taken.

Illustration of A Brush Arbor. Illustration found on: http://confederatelegion.com/Brush Arbor Days.html. (viewed on March 26, 2014).

Illustration of A Negro Camp Meeting in the South. Illustration found on: http://nonebutgod1.blogspot.com/2012/09/a-brush-arborservice.html\#.UzwLkJTD_IU. (viewed on March, 26, 2014).

Illustration of Certificate Degree of Indian Blood, found on: http://publicradiotulsa.org/post/baby-veronica-case-stirs-questions-about-bloodquantum-hear-our-special-report (viewed on March 26, 2014). 
Illustration of John Cornsilk's blue card for tribal citizenship status in the Cherokee Nation, found on:

http://www.network54.com/Forum/237458/message/1286717726/Yes+Bill+I+sus pect + David + voted + for + it,+ as + I + would + probably + have, + if + we + gotta + live + with the (viewed on March 26, 2014).

Jackson, Donald. Letters of the Lewis and Clark Expedition, with related documents, 1783-1854. Urbana: University of Illinois Press, 1962.

Jackson, Tesina. "Stick Ross: Tahlequah pioneer and civic leader." Cherokee Phoenix (Tahlequah), March 3, 2011.

Jennings, Julianne. "Cherokee Freedmen: One Year Later." Indian Country Today Media Network, January 31, 2012. http://www.indiancountrytodaymedianetwork.com/ict_sbs/Cherokee-freedm. (accessed July 13, 2013). 1-2.

Joll, James. Antonio Gramsci. New York, NY: The Viking Press, 1977. 16. Juozapavicius, Justin. "Cherokees Revoke Benefits for 2,800 Slaves' Offspring Cut From Tribal Rolls." Arkansas Democrat-Gazette (Little Rock), September 10, 2011. $5 \mathrm{~A}$.

Kappler, Charles. "Indian Affairs: Laws and Treaties. Vol. 6, Laws." Indian Affairs: Laws and Treaties. Vol. 6, Laws. http://digital.library.okstate.edu/kappler/Vol6/html_files/v6p1208b.html (viewed on May 23, 2014). 
Kelly, Casey Ryan. "Blood-Speak: Ward Churchill and the Racialization of American Indian Identity." Communication and Critical/Cultural Studies 8, no. 3 (2011): 240-265.

La Vere, David. “Of Wannabes and Indians,” 2011, Viewed on August 1, 2014 http://davidlavere.com/of-wannabes-and-indians/

Lears, T. J. Jackson. "The Concept of Cultural Hegemony: Problems and Possibilities." The American Historical Review 90, no. 3 (1985): 567-593.

Library of Congress Virtual Programs and Services. "Primary Documents in American History." 14th Amendment to the U.S. Constitution: Primary Documents of American History (Virtual Programs \& Services, Library of Congress). http://www.loc.gov/rr/program/bib/ourdocs/14thamendment.html (accessed February 19, 2014).

Littlefield, Daniel F. The Cherokee Freedmen From Emancipation to American Citizenship. Westport, Conn.: Greenwood Press, 1978. 54, 58-60, 65, 130-131. Martin, Denise. "Pan African Metaphysical Epistemology: A Pentagonal Introduction." The Journal of Pan-African Studies 2, no. 3 (2008): 213, 219.

Martin, Robert. "The Cherokee Phoenix: Pioneer of Indian Journalism." Chronicles of Oklahoma 25, 1947, Summer edition. 102-118.

McGhee, Jones, R. and Varms, Richard. Theory in Social and Cultural Anthropology: An Encyclopedia. Thousand Oaks: Sage Publications, 2013. 945.

Miles, Tiya, and Sharon Patricia Holland. Crossing waters, crossing worlds: the African diaspora in Indian country. Durham: Duke University Press, 2006. 149. 
Miles, Tiya. Ties that bind: the Story of an Afro-Cherokee Family in Slavery and Freedom. Berkeley: University of California Press, 2005. 4, 96, 111.

Monet, Jenni. "Freedmen Present Case: D.C. Circuit hears oral arguments in Cherokee Freedmen treaty dispute; Cherokee Nation repeats call to dismiss the case." Indian Country Today, November 7, 2012. 12-13.

Nantambu, Kwame. "Origin of terms 'Negro' and Afrika." Trinicenter.com. http://www.trinicenter.com/kwame/2007/0901.htm (accessed May 23, 2014). National Congress of American Indians. "An Introduction to Indian Nations in the United States." National Congress of American Indians. http://www.ncai.org/abouttribes/Indians_101.pdf (accessed February 17, 2014). 3.

Naylor, Celia E. African Cherokees in Indian Territory: From Chattel to Citizens. Chapel Hill: University of North Carolina Press, 2008. 1, 98-99.

Perdue, Theda. "Mixed blood" Indians racial construction in the early South. Athens: University of Georgia Press, 2003. 70-103.

Perdue, Theda. "Native Americans, African Americans, and Jim Crow." In Indivisible: African-Native American lives in the Americas. Washington, D.C.: Smithsonian Institution, 2009. 21.

Perdue, Theda. Slavery and the Evolution of Cherokee Society, 1540-1866. Knoxville: University of Tennessee Press, 1979. 36.

Personal photo taken of an ad presenting the Benefits of Working for the Cherokee Nation, Cherokee Phoenix, September 2003, 4.

Personal photo taken of an ad presenting a CDIB Discount of $\$ 500$ on a New or Used Car, Cherokee Phoenix, August 2006, 5.

Pratt, Richard, and Robert Utley. Battlefield and Classroom: Four Decades with the American Indian, 1867-1904. Norman, OK: University of Oklahoma Press, 1964. XI-XV. 
Prince, Richard. "Cherokee Nation Ousts Blacks - NAM." Cherokee Nation Ousts Blacks - NAM., Washington Afro American, March 10, 2007. http://news.newamericamedia.org/news/view article.html?article id=52479470 a382404773a316f3c798334f (viewed on April 13, 2014).

Reyhner, Jon Allan, and Jeanne M. Oyawin Eder. American Indian Education: A History. Norman: University of Oklahoma Press, 2004. 132-134.

Robertson, Tom. "White Earth Nation Vote Could End 'Blood Quantum' Tribal Membership Requirement." MPRnews (Ponsford), January 16, 2013. http://www.mprnews.org/story/2013/11/20/politics/white-earth-band-votes-toend-blood-quantum-for-tribal-membership-- (accessed February 18, 2014).

Rodgers, Joseph. Cherokee Advocate (Tahlequah), September 9, 1876. 3.

Ross, Gayle. "Facts don't interest Watson." Cherokee Phoenix (Tahlequah), November, 2007, sec. Talking Circles.

Samuels, Adrienne. "What Does Indian Blood Look Like?." Ebony, April 2008. 94104.

Sandefur, G., "American Indian reservations: The first underclass areas?" Focus 12, no.1 Summer, (1989) 37-41.

Saunt, Claudio. "The Paradox of Freedom: Tribal Sovereignty and Emancipation During the Reconstruction of Indian Territory." Journal of Southern History 70, no.1 (2004): 87.

Shelton, Jerrold Paul. "An Immodest Proposal." Cherokee Phoenix (Tahlequah), October, 2007, sec. Talking Circles. A-4.

Sho-Ban News (Fort Hall). "Obama: Let courts decide Freedmen issue," May 14, 2008. 4.

Shoemaker, Nancy. "How Indians Got to be Red." The American Historical Review 102, no. 3 (1997): 624-644.

Silver, Shirley, and Wick R. Miller. American Indian languages: cultural and social contexts. Tucson: University of Arizona Press, 1997. 195, 197-198.

Smith, Chad. "All should be supporting sovereignty." Cherokee Phoenix (Tahlequah), August, 2007, sec. Talking Circles. A-4. 
Smith, Robert. "Cherokee Lawsuit's Focus on Citizenship." Arkansas DemocratGazette (Little Rock), February 16, 2009.

Smith, Ronald. "The Cherokee-Freedmen Story: What The Media Saw." In Shoot The Indian: Media Misinterpretation and Native Truth. Buffalo, NY: American

Indian Policy and Media Initiative, 2007. 1-5.

Socrates. "Intermarriages." Cherokee Phoenix (New Echota), March 27, 1828, 1, no.6 col. 4a.

Staples, Brent. "When Racial Discrimination Is Not Just Black and White." The New York Times, September 12, 2003. 2-3.

Starr, Emmet. History of the Cherokee Indians. Cherokee, NC: Cherokee Publications, 2009. 169-170, 277-279, 282-283.

Stremlau, John. "Black Cherokees exercise hard-won right to vote." CNN, October 19, 2011. 1-2.

Strickland, Rennard. "Genocide-at-Law: An Historic and Contemporary View of the Native American Experience." Kansas Law Review 34, no. 4 (1986): 713-756. http://works.bepress.com/rennard_strickland/114 (accessed December 9, 2013).

Sturm, Circe. Blood politics: race, culture, and identity in the Cherokee Nation of Oklahoma. Berkeley: University of California Press, 2002. 31, 33, 43.

Sturm, Circe. "Blood Politics, Racial Classification, and the Cherokee National Identity: The Trials and Tribulations of the Cherokee Freedmen”, American Indian Quarterly, 22, no. (1/2), (Winter-Spring), 1998: 250.

The Underground Railroad. VHS. Directed by Susan Michaels. New York: History Channel:, 2002.

The United States Court of Appeals for the District of Columbia Circuit, Marilyn Vann v. Department of Interior. Case No, 1:03-cv-01711. 47.

The Vinita Weekly Chieftain 11, no. 48, July 30, 1903. 
Thyer, Bruce A.. Cultural Diversity and Social Work Practice. 3rd ed. Springfield: Charles C. Thomas Publisher, 2010. 29.

Velie, Jonathan. "Bureau of Indian Affairs Recognizes Cherokee Election Although Black Citizens Forbidden Right to Vote." In Velie \& Velie Attorneys at Law Press Release, August 7th, 2003, 2.

Vestal, Christine., "Affordable Care Act a hard sell for Native Americans," USA Today, October 15, 2013, viewed on July 29, 2014, http://www.usatoday.com/story/news/nation/2013/10/15/stateline-obamacarenative-americans/2986747/.

Volo, James M., and Dorothy Denneen Volo. Family Life in Native America. Westport, Conn.: Greenwood Press, 2007. 51.

Washington, Booker T. The Story of the Negro; The Rise of the Race From Slavery. New York: Doubleday and Company Inc., 1909. 138.

Washington, Booker T. Up From Slavery, an autobiography. Garden City, N.Y.: Doubleday, 1963. 68-69.

Washington, Olvie. "CN needs real sovereignty." Cherokee Phoenix (Tahlequah), June, 2007, sec. Talking Circles. A-4.

Washington, Olvie. "Identity is a higher priority." Cherokee Phoenix (Tahlequah), September, 2007, sec. Talking Circles. A-4.

Wa Thiongo, Ngugi. Something Torn and New: An African Renaissance. Philadelphia, PA: BasicCivitas Books, 2009. 7.

Wickett, Murray R.. Contested Territory: Whites, Native Americans, and African Americans in Oklahoma, 1865-1907. Baton Rouge: Louisiana State University Press, 2000. 31, 51, 68-69,172-173,183.

Williams, Heather. "Let Cherokees decide who's Cherokee." Cherokee Phoenix (Tahlequah), August, 2007, sec. Talking Circles. A-4. 
Williams, Samuel Cole. Early travels in the Tennessee country, 1540-1800: With Introductions, Annotations and Index. Johnson City, Tenn.: Watauga Press, 1928. 152-153.

Williamson, Terrion. (2004) “The Plight of the 'Nappy Headed' Indians: The Role of Tribal Sovereignty in the Systematic Discrimination Against Black Freedmen by the Federal Government and Native American Tribes", Michigan Journal of Race and Law 10, no. 233 (2004): 262.

Wilson, Clint C. F. lix Gutiérrez, and Lena M. Chao. Racism, Sexism, and the Media: the Rise of Class Communication in Multicultural America. 3rd ed. Thousand Oaks, Calif.: Sage Publications, 2003. 68, 278.

Wilson, Shawn. Research is Ceremony: Indigenous Research Methods. Black Point, N.S.: Fernwood Pub. 2008. 74, 77.

Wilkins, David E.. American Indian politics and the American political system. Lanham, MD: Rowman \& Littlefield. 2002. 24.

Yarbrough, Fay A. Race and the Cherokee Nation: Sovereignty in the Nineteenth Century. Philadelphia: University of Pennsylvania Press. 2008. 36, $125-126$.

Zack, Naomi. Race and mixed race. Philadelphia, PA: Temple University Press, 1993. 83. 


\title{
CURRICULUM VITAE
}

\author{
Shannon M. Spears \\ 503 Churchill Court Elizabethtown, KY, 42701 \\ smspea01@cardmail.louisville.edu (270)307-5677
}

\section{Education:}

University of Louisville, Louisville, KY

Bachelor of Arts, Majors: Humanities and Pan-African Studies, December 2011 Dean's List Spring 2009

Graduate Certificate, African American Theatre January 2012-December 2013

Master of Arts, Major: Pan-African Studies, August 2014

Graduate Dean's Citation Award May 2014

University of the West Indies, Trinidad and Tobago

Study Abroad Participant, July 14, 2011-August 2, 2011

\section{Honors:}

De Marzo Farley Award, Summer 2011

Harold Adams Scholarship, Spring 2012

Alpha Omicron Pi Diamond Jubilee Scholarship, Fall 2012

Pan-African Studies Study Abroad Graduate Assistantship, Fall 2012-Present

\section{Research Interests:}

African American Theatre; Cultural Diversity in Performance; August Wilson Native American, African and African American Studies; Cherokee Freedmen; Cultural Identity; Classification; Citizenship within Native American Nations; Blood Quantum Requirements; and HIV/AIDS in Native American Youth

\section{Research Experience:}

Sequoyah National Research Center, University of Arkansas at Little Rock Little Rock, AR

Summer Intern, June $2^{\text {nd }} 2013-J u l y ~ 31^{\text {st }} 2013$ 
- Recorded inventory on rolls of microfilm, which were collections of Historical Native American Newspapers, into CuadraStar Archives Management

- Collected articles from the Cherokee Phoenix newspaper and legal documents for Master's Thesis Research on the Cherokee Freedmen and how they have articulated a sense of cultural identity and citizenship claims over time

- Conducted a content analysis of the newspaper articles and legal documents

\section{Publication:}

Spears, Shannon. Summer 2013. “Following My Dreams,” To Dragma, 77 (3):60-61.

\section{Conference Paper:}

"The Political Branding of Martin Luther King Jr., Booker T. Washington, and Malcolm X," National Council for Black Studies Conference, March 5-8, 2014 Miami, FL.

\section{Activities:}

Native American Student Organization (NASO)

Member, Spring 2013-Present

Pan-African Graduate Student Association (PGSA)

Fundraising Chair, Fall 2012-Present

Golden Key International Honor Society

Member, Fall 2012-Present

Sigma Alpha Lambda Honor Society

Member, Fall 2010-Spring 2011

PanHellenic Office, University of Louisville, Louisville, KY

Gamma Chi, Summer 2010

Alpha Omicron Pi Sorority, University of Louisville, Louisville, KY

Vice President of Education, Spring 2010-Fall 2010

Alpha Omicron Pi Sorority, University of Louisville, Louisville, KY

New Member Educator, Fall 2009

Honorable Order of Kentucky Colonels

Member, 2008-Present

Disabled American Veterans Auxiliary

Member, 2006-Present

Volunteer and Service Learning Experience;

University of Louisville Women's Conference 
Volunteer Coordinator May 2012

- Recruited volunteers for the Women's Conference

- Assigned responsibilities to the volunteers

Lac Du Flambeau Ojibwe Native American Reservation Service Learning Trip, Lac Du Flambeau, WI

- Cleaned and straightened the donation room at the Women's Thunderbird House, a domestic abuse center on the reservation

University of Louisville Service Learning Program Botswana, Botswana, Africa

- Taught lessons on the topics of Dr. Martin Luther King Jr. and Native American History to 14-year-old students at Maoka village

- Provided instruction for making dream catchers

- Went to Hope Mission orphanage to provided games and crafts for the children

\section{Academic Service:}

Pan-African Studies Graduate Assistant

Recruiter for Study Abroad Program and African American Theatre Program Fall 2012Present

- Held 20 office hours a week

- Promoted the Study Abroad Trip to Trinidad and Tobago at study abroad fairs

- Made posters and flyers advertising the trip

- Visited classes to speak to students about the trip

- Organized and facilitated meetings

- Updated students on due dates for paperwork and payments

- Responsible for taking required paperwork to the university's international center

- Encourage students to apply for the African American Theatre Program

\section{Other Job Experience:}

Speed Art Museum, Louisville, KY

Visitor Services March 2012-September 2012

- Sold tickets and memberships at the front desk

- Assist visitors with directions to exhibits

- Worked in the gift shop pricing and selling souvenirs

- Checked the inventory of products

- Held responsibility for drawer, did deposits and count

- Gave daily reports

University of Louisville Housing, Louisville, KY

Desk Assistant Fall 2010-Summer 2011

- Manned the front desk in the residence halls that I worked in

- Made sure that students followed all of the housing rules

- Reported any incidents or repairs necessary 